Florida International University FIU Digital Commons

6-23-2016

\title{
Anarchy and Anti-Intellectualism: Reason, Foundationalism, and the Anarchist Tradition
}

Joaquin A. Pedroso

jpedroso@fiu.edu

DOI: $10.25148 /$ etd.FIDC000744

Follow this and additional works at: https://digitalcommons.fiu.edu/etd

Part of the Philosophy Commons, and the Political Theory Commons

\section{Recommended Citation}

Pedroso, Joaquin A., "Anarchy and Anti-Intellectualism: Reason, Foundationalism, and the Anarchist Tradition" (2016). FIU Electronic Theses and Dissertations. 2578.

https://digitalcommons.fiu.edu/etd/2578

This work is brought to you for free and open access by the University Graduate School at FIU Digital Commons. It has been accepted for inclusion in FIU Electronic Theses and Dissertations by an authorized administrator of FIU Digital Commons. For more information, please contact dcc@fiu.edu. 


\section{FLORIDA INTERNATIONAL UNIVERSITY}

Miami, Florida

\section{ANARCHY AND ANTI-INTELLECTUALISM: REASON, FOUNDATIONALISM, AND THE ANARCHIST TRADITION}

A dissertation submitted in partial fulfillment of the

requirements for the degree of

DOCTOR OF PHILOSOPHY

in

POLITICAL SCIENCE

by

Joaquin A. Pedroso

2016 
To: Dean John F. Stack, Jr.

Steven J. Green School of International and Public Affairs

This dissertation, written by Joaquin A. Pedroso, and entitled Anarchy and AntiIntellectualism: Reason, Foundationalism, and the Anarchist Tradition, having been approved in respect to style and intellectual content, is referred to you for judgment.

We have read this dissertation and recommend that it be approved.

Paul Warren

Bruce Hauptli

Ronald Cox

Harry Gould

Clement Fatovic, Major Professor

Date of Defense: June 23, 2016

The dissertation of Joaquin A. Pedroso is approved.

Dean John F. Stack, Jr. Steven J. Green School of International and Public Affairs

Andrés G. Gil

Vice President for Research and Economic Development and Dean of the University Graduate School

Florida International University, 2016 


\section{DEDICATION}

To my mother and father. 


\section{ACKNOWLEDGMENTS}

This dissertation would have been impossible were it not for the generous assistance of many people. I would first like to acknowledge the hard work of my dissertation committee. I would like to thank the head of my dissertation committee, Professor Clement Fatovic, for his patient and steadfast guidance throughout this project. He has served as an example of both scholarly and pedagogical integrity. I would also like to thank Professor Harry Gould for his pragmatic advice on academic matters. I think I have absorbed and internalized his grounded humility and anti-foundationalist approach to teaching and scholarship. I would like to thank Professor Ronald Cox for his unwavering support of not only this project but also his support of and concern for the graduate student body. His solidarity with students is an inspiration for my own work. I would also like to thank Professor Bruce Hauptli for his dedication to this project and for his detailed, insightful, and constructive feedback. I am especially grateful for his eagerness to tackle the philosophical content of the project and his enthusiastic encouragement throughout the whole process. Moreover, if it were not for the direct and constructive criticism of Professor Paul Warren this dissertation would have never taken the shape it has. His disagreements with the scope of the project helped me sharpen my aims and better understand exactly what I was up to.

This dissertation would not have been possible were it not for the generous funding of the Department of Politics and International Relations at Florida International University. I would also like to thank the English Department at Florida International University for the opportunity to participate in the Interdisciplinary Writing Teaching 
Assistantship program that not only facilitated two extra years of funding but also afforded me an opportunity to engage with interesting pedagogical material I would have otherwise not tackled. The faculty in the Department of Politics and International Relations has been central to providing a stimulating atmosphere and an intellectual space for conceiving of this project. I would like to especially thank Professor Rebecca Salokar for striving to maintain a warm and welcoming environment that is mirrored in the graduate student body. She is an inspiration in more ways than one. I would also like to thank Professor Tatiana Kostadinova for her help in tying loose administrative ends and helping me finalize this project. I would also like to thank the wonderful staff at the Department of Politics and International Relations who consistently and enthusiastically help me with administrative matters that can rack the brain to the point of exhaustion. They have been invaluable throughout my graduate education. It was a genuine pleasure to share many informal conversations, espresso coffees, and occasionally office space with them.

I have benefitted from informal talks with many professors and colleagues including Professor Judith Stiehm, Professor Dario Moreno, Professor George Kovacs, Professor Ingvild Torsen, Professor Francois Debrix, Professor Sean Walsh, Bryant Sculos, Nicolas Terradas, Yonas Mulat, Fiacre Bienvenu, Mirsad Krijestorac, Nima Baghdadi, Sylvan Lee, Ana Podcameni, Randford Edwards Jr., Thomas J. Liguori, and many others. I would like to especially thank Professor Juan Carlos Espinosa for his guidance and special insight into our shared cultural heritage and how it relates to navigating academia. Though many of these discussions were often only tangential to the content of this dissertation they nevertheless helped shape its contours. 
I would also like to thank friends outside of the department with whom I engaged and tested the material in this dissertation and who helped tame my many moments of frustration and occasionally pushed me to overcome my emotional funks during the writing process, even if unwittingly. Juan Cuba, Jenny Blando, Laura Ortega Palma, and Eduardo Palma deserve special recognition for regularly being my intellectual punching bags and for being eager to hit back. I know I have grown, professionally, intellectually, and personally, with their help and I am thankful for their sincere friendship.

Relating basic concepts of anarchy to issues of social justice over many coffee breaks involving stimulating hours-long conversations with Professor Maria Willumsen is something I am especially thankful for. Her vitality and dedication to what matters continues to animate my work. I would also like to thank the graduate student body as a whole for providing a collegial and welcoming atmosphere as well as thank my students who passionately engage with me and indulge me in what I love. In particular, I would like to thank Rachel Stevens, whose senior thesis I supervised, whose own struggles with writing and tackling a difficult, often nebulous, subject matter taught me the importance of considering ourselves perpetual beginners. She is proof that we often learn plenty from those who do not think themselves in a position to teach.

They all, in one way or another, helped me solidify my views, sharpen my arguments, or simply garner inspiration and encouraged me to tackle unpopular topics in academia. Any faults are, of course, solely the responsibility of the author.

Lastly, without the unconditional love and unfailing support of my family this project would never have been completed. 
ABSTRACT OF THE DISSERTATION

ANARCHY AND ANTI-INTELLECTUALISM: REASON, FOUNDATIONALISM, AND THE ANARCHIST TRADITION

\author{
by \\ Joaquin A. Pedroso \\ Florida International University, 2016 \\ Miami, Florida \\ Professor Clement Fatovic, Major Professor
}

Some contemporary anarchist scholarship has rejected the Enlightenment-inspired reliance on reason that was supposedly central to classical anarchist thought and expanded the anarchist critique to address issues ignored by their classical predecessors. In making reason the object of critique, some contemporary anarchists expanded the anarchist framework to include critiques of domination residing outside the traditional power centers of the state, the capitalist firm, and the church thereby shedding light on the authoritarian tendencies inherent in the intellect itself.

Though contemporary anarchist scholarship has sought to apply this antiauthoritarian ethos to the realms of epistemology and ontology (by employing Michel Foucault's analysis of power and other postfoundational thinkers), their own framework of analysis is glaringly susceptible to what Habermas called a "performative contradiction." In questioning the authority of aspects of even our own intellect (and the epistemological and ontological presuppositions that accompany it) we call into question even the authority of our own argumentation. 
I answer this "contradiction" by interrogating two intellectual traditions. Firstly, I question a key postfoundational anarchist premise. Namely, I assess whether an understanding of classical anarchist thinkers as quintessential children of the Enlightenment is justified. Secondly, I offer an alternative path to reconciliation between the anti-authoritarian values of the anarchists and the anti-metaphysical values of the postfoundationalists (that I think mirrors anarchist anti-authoritarian concerns) by suggesting we are better served to think of an anti-authoritarianism of the intellect by employing three key twentieth century thinkers: Richard Rorty, Paul Feyerabend, and Ludwig Wittgenstein. I do so while anchoring Rorty's, Feyerabend's, and Wittgenstein's philosophies in the 19th century anti-metaphysical thought of Friedrich Nietzsche and the philosophical anarchism of Max Stirner. 


\section{TABLE OF CONTENTS}

CHAPTER

PAGE

Introduction: Anarchy, Reason, and Anti-Intellectualism..........................

Chapter 1: Contextualizing and Theorizing Anarchist Anti-Intellectualism.............25

Chapter 2: Reason, Anti-Intellectualism, and the Reluctant Modernism of William

Godwin and Pierre-Joseph Proudhon............................................48

Chapter 3: Reason, Science, and Anti-Intellectualism in Mikhail Bakunin and Peter

Kropotkin................................................................. 89

Chapter 4: Anti-Authoritarianism as Anti-Intellectualism: Stirner, Nietzsche, and the

Anarchic Politics of Postfoundationalism...................................... 136

Conclusion: Towards Public Irony ........................................ 183

Bibliography.............................................................206

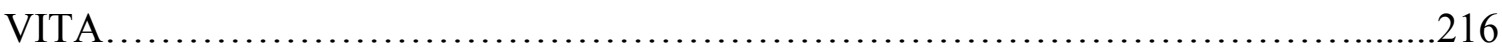




\section{Introduction}

\section{Anarchy, Reason, and Anti-Intellectualism}

Anarchy, first employed in its modern non-derogatory sense by Pierre-Joseph

Proudhon, has been understood in anarchist circles since the $19^{\text {th }}$ century as "the absence of a master, of a sovereign." More than simply a protest against the relational dynamic between master and slave or sovereign and subject, anarchy was understood by Proudhon and other so-called classical anarchists to be fundamentally anti-authoritarian. ${ }^{2}$ They stood firmly against relations and structures of domination and coercion in the realm of the political, the social, and the economic. Anarchic anti-authoritarianism took aim at all social structures of domination, from the spiritual domination of organized religion, to the coercive governance of state systems, to the alienating and exploitative nature of capitalism as well as the relations of domination inherent in the inequalities bred from these structures. ${ }^{3}$

Even though scholars agree that the classical anarchists forcefully challenged the authority of countless institutions and practices, many claim they never challenged the authority of Reason. ${ }^{4}$ Despite their anti-authoritarian ethos, many claim classical

\footnotetext{
${ }^{1}$ Pierre-Joseph Proudhon, What is Property? ed. Donald R. Kelley and Bonnie G. Smith (Cambridge: Cambridge University Press, 1994), 209.

${ }^{2}$ The "classical" anarchists include William Godwin, Pierre Joseph Proudhon, Mikhail Bakunin, Peter Kropotkin, as well as their immediate followers such as Rudolph Rocker, Emma Goldman et al.

${ }^{3}$ See for example, Robert M. Cutler, ed., trans. The Basic Bakunin: Writings, 1869-1871 (Buffalo, NY: Prometheus, 1992); Peter Kropotkin, The Conquest of Bread and Other Writings. Ed. Marshall S. Shatz (Cambridge: Cambridge University Press, 1995); Pierre-Joseph Proudhon, The General Idea of the Revolution in the Nineteenth Century. Trans. John Beverly Robinson (London: Pluto Press, 1989).

${ }^{4}$ Scholars who critique the classical anarchist reliance on Reason include Saul Newman, Lewis Call, and Todd May.
} 
anarchists seemed oblivious to the authoritarian potential of Reason itself as well as its auxiliary ideological notions like scientism and human nature. ${ }^{5}$ Proudhon himself reflexively relied on the authoritative signaling of Reason as the unquestioned methodology for arriving at truth, the arrival at truth itself being a prerequisite for any meaningful exercise of liberty in the face of these perceived structures of domination. In noting that "the opinion of no one is of any value until its truth has been proven, no one can put his will in the place of reason - no one is king,"6 Proudhon reinforced what many anarchists seemingly took for granted, namely the authority of Reason as both a liberating vehicle and as a prerequisite for the liberation of humanity. These consummate antiauthoritarians seemed to reinforce and extend the authority of Reason in both employing and celebrating it as the foundation for anarchic anti-authoritarianism.

Some contemporary anarchist scholarship has rejected the reliance on Reason that seemed crucial to classical anarchist thought and expanded the anarchist critique to address issues once supposedly ignored by their classical predecessors. In making Reason the object of critique, some contemporary anarchists identified structures of domination in realms other than the political, the economic, or the social. Moreover, in expanding the anarchist framework to include critiques of domination residing outside the traditional power centers of the state, the capitalist firm, and the church,

\footnotetext{
${ }^{5}$ When referring to Reason (capital R) I am referring to Reason considered both as a faculty and as an ideal. Otherwise, I will refer to reason (lower case $r$ ) when referring only to the faculty or to causes and explanations for something.

${ }^{6}$ Proudhon, Property, 209.
} 
contemporary anarchist scholarship shed light on the authoritarianism inherent in even our own intellect.

Recent anarchist scholarship has sought to rectify this apparent oversight of the classical anarchists. Some contemporary anarchists have applied this anti-authoritarian ethos to the realms of epistemology and ontology (particularly to issues addressing the legitimacy of the authority of Reason, representation, universality, and essentialist categories and frameworks of analysis). This study will explore the trajectory of anarchist thought (from the classical anarchism of the $19^{\text {th }}$ century to contemporary postfoundational anarchism, which, like Saul Newman, I will collectively refer to as postanarchism) and the feasibility and coherence of anarchist principles not only in the political realm but also in the realm of epistemology and ontology (especially as they relate to the ideal of Reason, science and scientism, and human nature). That is, my purpose is to sketch what a consistent anarchism would look like in the epistemological and ontological spheres, which I refer to collectively as the "intellectual."

The danger inherent in questioning even sacrosanct bulwarks of our intellect (e.g., Reason) is the possibility of falling into incoherence. In questioning the authority of aspects of even our own intellect (and the epistemological and ontological presuppositions that accompany it) we call into question even the authority of our own argumentation. At the very least we call into question whether such an endeavor is even possible.

As I will argue, the postanarchist endeavor seems susceptible to incoherence when it decries the use of Reason while providing a sometimes-caricatured reading of the so-called classical anarchists with regard to the question of intellectualism. The question I 
ask is whether a critique of Reason (and, according to postanarchists, the essentialist ideas, methodological hierarchies, and universalities that usually accompany it) that does not rely on those same ideas even possible. Is it even possible for postanarchists to coherently critique the classical anarchist reliance on Reason without having those critiques somehow convey notions which themselves rely on essentialist ideas, methodological hierarchies, or universalities apparently unavoidable in Western political thought?

Ever since Plato's attempt to establish the foundations of a just society on rational principles, Reason has shaped the contours of Western intellectual life and still continues to permeate the modern technocratic and instrumental society that critics of the Enlightenment have assailed, serving as the basis for most theoretical constructs of political order. While the ancient ideal of Reason rests on an unchangeable archetype or is understood to be the source of first principles (most notably the idea of noncontradiction in Aristotle) needed to arrive at truth, medieval thinkers like Thomas Aquinas argued certain religious notions exceeded the capacities of human reason yet some theological truths could be attained through our faculty of reason. ${ }^{7}$

Modern thinkers like Rene Descartes and John Locke considered our individual exercise of reason as the vehicle to arrive at truths once promised alone by faith or unchanging archetypes accessible to a privileged few. Descartes considered the senses a

\footnotetext{
${ }^{7}$ Thomas Aquinas, Of God and His Creatures: An Annotated Translation (with some abridgments) Summa Contra Gentiles, trans. Joseph Rickaby (Westminster, MD: The Carroll Press, 1950), 7. However, this same faculty of reason was understood by Aquinas as inherently limited and unable to conceive fully of the omniscience and omnipotence of God and would always be a less noble pursuit than the exercise of faith. See Aquinas, Of God and His Creatures, 228.
} 
source of "uncertainty and error" and considered unmitigated reason his means of escape from such epistemological and ontological insecurity once alleviated by faith. ${ }^{8}$ Relatedly, while Locke considered faith "above reason" Locke recognized that through our faculty of reason we might come to know truths more certainly than by revelation and that the "clear evidence of reason" obviates any need of revelation. ${ }^{9}$ Nevertheless, our reason is necessarily insufficient and often "puzzled" because our ideas with which we reason are "imperfect" and "obscure" and principles often "false."10 David Hume and Immanuel Kant also personalized Reason to be understood as on the one hand inherently limited (as in Hume's critique of induction and Kant's insistence of the inaccessibility of the noumenal) and subject to our own ends (even if derived from rational principles as in Kant's Categorical Imperative, yet not exclusively reliant on Reason as in Hume's sentimentalism) as opposed to dependent on a transcendent Good. ${ }^{11}$

In other words, while the ancients largely relied on Reason to determine objective truth about ultimate ends or the good life (these notions being otherworldly), medieval thinkers usually prized faith in God as both the ultimate end and inevitable outcome of the proper exercise of reason. Modern thinkers often thought of Reason as a means of

\footnotetext{
${ }^{8}$ Harry G. Frankfurt, Demons, Dreamers, and Madmen: The Defense of Reason in Descartes's Meditations (New York: The Bobbs-Merril Company, 1970), 4. See also, Rene Descartes, Discourse on Method; and, Meditations on First Philosophy, trans. Donald A. Cress (Indianapolis: Hackett, 1998).

9 John Locke, An Enquiry Concerning Human Understanding, ed. Kenneth P. Winkler (Indianapolis: Hackett, 1996), 325.

${ }^{10} \mathrm{Ibid}, 320$.

${ }^{11}$ See David Hume, A Treatise of Human Nature, ed. David Fate Norton and Mary J. Norton (Oxford; New York: Oxford University Press, 2000); Immanuel Kant, Critique of Pure Reason, trans. Norman Kemp Smith (New York: St. Martin's Press, 1965); Kant, Critique of Practical Reason, trans. Lewis White Beck (Indianapolis: Bobbs-Merill, 1956).
} 
determining a subjective good and considered otherworldly notions like the good life and God to be largely beside the personalized aims of Reason. For Moderns like Descartes, Locke, Hume, Kant, and others, while the exercise of our most prized faculty could certainly reinforce the findings of faith it also served, more importantly, as our individual means to "clearly" and "distinctly" assess reality (a concern independent of our faith and matters of "salvation"). Though the modern individualist rendering of our most prized faculty often highlighted its limitations it also clearly celebrated it as a guide to rendering our world intelligible.

Politically, the ancient employment of Reason justified the construction of a "noble lie" ${ }^{12}$ which served to create meaning and value for ends that only a rational few could grasp and existed independently of those striving to achieve these ends. ${ }^{13}$ The ancient ideal focused on unchanging principles that grounded all further knowledge that existed independently of our own ends. Though Aristotle recognized the role of desire and habit in shaping our ends they were subject to the authority and control of Reason that shaped the ultimate end and validated the quest for truth. Likewise, Reason would complement and reinforce revelation in medieval thought but would hardly stand as a substitute for the ultimate grounding of both meaning and knowledge, God. Though it is difficult to generalize, this reinforcement would often legitimize political orders based on subservience to existing authority and adherence to ostensible Biblical mores.

\footnotetext{
${ }^{12}$ See Leo Strauss, Persecution and the Art of Writing (Chicago: University of Chicago Press, 1998).

${ }^{13}$ Michael Oakeshott, Rationalism in Politics and Other Essays (Indianapolis: Liberty Press, 1991), 10. See also book VI of Plato, Republic, trans. Robin Waterfield (Oxford; New York: Oxford University Press, 1994).
} 
The modern individualist conception of Reason on the other hand is deployed as a means for personal and political liberation accessible to all and couched in a seemingly indefatigable optimism, present especially in radical thought, in our ability to rationally order society to fit our ends. Rather than thinking of Reason as a faculty accessible only through some kind of transcendent know-how, as a gift from God to be used only for predetermined ends, or as the guarantor of truth, the modern employment of Reason was subject to the limitations and aims of the individual exercising it.

Despite their differences, the ancient, medieval, and modern conceptions of Reason all consider Reason as an authoritative measure of knowledge that serves as a foundation for political order. The authority of Reason championed, for example, by Plato's philosopher kings or Aristotle's conception of the good life is likewise understood as the primary foundation of modern constructs of political order. ${ }^{14}$ In other words, modern critiques still rely on a privileging of Reason to both justify new political authority and critique existing ones. The ancient and modern employments of Reason are not fundamentally different in that they both celebrate and continue to bestow a privileged status on Reason.

It is claimed that the privileged position of Reason is especially evident in the anarchism of thinkers like William Godwin, Pierre Joseph Proudhon, Mikhail Bakunin,

\footnotetext{
${ }^{14}$ See Book III of Aristotle's Politics where he describes the end of the state as "the good life" and admits that "political society exists for the sake of noble actions" to which only a few can contribute (1280b39 1291a8). Likewise, modern orderings of what Aristotle called "political society" rely on Reason by deducing appropriate regime types from certain conceptions of human nature (as in Hobbes and Locke) or seeing a flourishing of (or approximation to) Reason as the ultimate end (as in deliberative models like Habermas' ideal of communicative rationality. See Jürgen Habermas, The Theory of Communicative Action, Vol. 1: Reason and the Rationalization of Society, trans. by Thomas McCarthy (Boston, MA: Beacon Press, 1984).).
} 
and Peter Kropotkin, all of whom apparently continued the Enlightenment tradition of harnessing the power of Reason to challenge the stifling effects of centralized state power, concentrations of wealth, and church dogma and are best known for delegitimizing the state and their rejection of institutions which justify arbitrary authority. ${ }^{15}$ These anarchists sometimes employed Reason in much the same way Plato did, exalting it in order to critique existing convention and custom and challenge what they perceived to be arbitrary authority.

The general aims and conceptual pillars of the anarchist tradition have usually been understood in terms of the social, economic, or political. That is, the employment of Reason in anarchist thought hinged on a stinging critique of organized religion, capitalism, and the state. Nevertheless, intellectual structures of domination (such as the privileging of Reason) seemingly remained unscathed by the anarchist critique according to some contemporary anarchist scholars. In other words, it is argued that anarchism has relentlessly debunked the idea of a need for power and privilege and condemned the domination inherent in all forms of government, the private firm, and the church but has paid little attention to power and privilege in the realm of the intellect.

Ironically, in this reading of the anarchist tradition, liberation from structures of domination (especially government) hinged on the unquestioned authority of Reason and its command over a gradual process of enlightenment. That is, anarchism's challenge of arbitrary authority and domination accepts and privileges the authority of Reason. What

\footnotetext{
${ }^{15}$ Self-proclaimed poststructuralist, postmodern, and postanarchist scholars like Todd May, Lewis Call, and Saul Newman claim the classical anarchist tradition is beholden to Enlightenment values that limit the radical potential of these anarchists.
} 
underlies the classical anarchist tradition generally was an exaltation of Reason and belief in auxiliary notions such as faith in a progressive advance towards truth or enlightenment, universality, ${ }^{16}$ and an essentialist representational view that considered the privileged faculty of reason as an integral part human nature. In other words, being notably absent from the classical anarchist anti-authoritarian tradition, a critical appraisal of Reason did not challenge the authority of these auxiliary claims central to supporting the anarchist anti-authoritarian view. These anarchists thought of society as "scientifically observable and determined by historical forces," human beings as imbued with "essential moral and rational characteristics which could flourish given the right social conditions," and a faith in a rationality that would overcome social and political oppression. ${ }^{17}$

According to this narrative, since its $19^{\text {th }}$ century beginnings, the privileged authority of Reason in anarchism remained unscathed until recent developments began to question its legitimacy. Godwin understood that "The true supporters of government are the weak and uninformed, and not the wise. In proportion as weakness and ignorance shall diminish, the basis of government will also decay." ${ }^{18}$ Godwin suggested a reliance on individual Reason as a means to overcome this human "weakness" and "ignorance" in order to be able to act with sound judgment and in liberty. Godwin notes,

\footnotetext{
${ }^{16}$ Where universality denotes an authoritative meaning of a certain concept or truth understood the same way in every context, i.e., independent of time, space, or community in which it is understood.

${ }^{17}$ Saul Newman, Unstable Universalities: Poststructuralism and radical politics (Manchester: Manchester University Press, 2007), 2.

${ }^{18}$ Robert Graham, ed., Anarchism: A Documentary History of Libertarian Ideas, 14.
} 
If a man be in some cases obliged to prefer his own judgment, he is in all cases obliged to consult that judgment, before he can determine whether the matter in question be of the sort provided for or no. So that from this reasoning it ultimately appears that the conviction of a man's individual understanding is the only legitimate principle imposing on him the duty of adopting any species of conduct... 19

It was only through an unquestioned privileging of and faith in our own rational capacities that we were able to resist existing forms of arbitrary authority. That is, in order to oppose "external" exercises of illegitimate authority, Godwin and others expected us to be subject to the "internal" authority of our own Reason.

Similarly, Proudhon noted that the state and right of property (by which he meant inherited wealth, accumulated interest on capital, and other monies not earned through labor or occupation and the law which protected and privileged it) undermined the potential of Reason to liberate humankind. He believed in the rational organization of society independent of the state (which enforced the right of property). According to Proudhon, the natural outgrowth of property was inequality and the natural outgrowth of inequality was deference. It was deference, or "the use of conventional standards of rank - mainly wealth, power, and prestige - to rate all members of society," that was the target of Proudhon's attack. ${ }^{20}$ These “conventional standards" were contrary to Reason for

\footnotetext{
${ }^{19}$ Ibid.

${ }^{20}$ Alan Ritter, The Political Thought of Pierre Joseph Proudhon (Princeton: Princeton University Press, 1969), 97.
} 
Proudhon and in seeking to liberate humankind Proudhon emphasized that freedom was unattainable with the existence of deference stemming from property.

He argued that wherever rank or hierarchy was present, freedom would be lacking. ${ }^{21}$ Indeed, Proudhon thought that "Deference engenders 'special perquisites, privileges, exemptions, favors, exceptions, all the violations of justice' - in short, oppression, including economic exploitation of the unprivileged." ${ }^{22}$ All hierarchy for Proudhon, even certain hierarchies necessary to redistribute wealth (e.g., state bureaucracies) created inequality and paved the way for deference. ${ }^{23}$ That is, even redistribution for the sake of complete material equality is an exercise in inequality for Proudhon. Those in charge of the mechanisms of distribution would wield a preponderance of power and it was only through the abolition of the state that humankind would be free and Reason allowed to flourish.

Likewise, Kropotkin based his anarchism on an animal nature (which he felt human beings shared) of cooperation. This cooperation is naturally enhanced by Reason. Kropotkin argued that through "mutual aid" animals (and human beings) survived and progressed as a species. Social conditions in the modern age, however, undermined this natural condition of humankind and instead encouraged competition as the way to

\footnotetext{
${ }^{21}$ Ritter notes "Choice can never be free where men view one another in graded hierarchy" in Proudhon, 96.

${ }^{22}$ Ibid, 97.

${ }^{23}$ Ibid, 99. According to Ritter, "The existence of inequality presupposes application of a rule that tells how much wealth, power, and prestige each member of society should receive. Such a rule, indicating how goods should be allocated among members of society, is an obvious example of a principle of distributive justice. Hence, if inequality is to be abolished so must its underlying distributive principle. All rules of distributive justice must be eliminated."
} 
progress. This move toward competition corrupted the individual, denying them their human essence. By eliminating the social institutions that promoted competition in the modern age, humankind would be able to freely exercise Reason and cooperate in a fashion where their human essence would again flourish. ${ }^{24}$ That is, in eliminating forms of societal authority the authority of Reason would prevail.

Bakunin also outlined the dangers of authority and state power, even if revolutionary in form. His debate with Marx over the inherent authoritarianism of state power led to his expulsion from the First International and highlighted his concern over authoritarian revolutionary means. Though he resisted authoritarian means to revolution, he unquestioningly accepted the authority of Reason in helping humankind discover the "natural laws" which held the promise of liberation. Bakunin was a staunch Enlightenment-inspired empiricist who rejected the idea that a human being's essential nature was that of the atomized individual (as propounded by defenders of capitalism). Instead he advocated a view that human beings naturally inclined towards freedom in the form of spontaneity, that they were "naturally social and always lived in communities" and that they instinctively orient themselves towards justice. ${ }^{25}$ This justice, for Bakunin, derives from his belief in Reason and natural human sociability. In drawing the distinction between the natural laws of, for example, human sociability (which are not enforced and need only be discovered via Reason and science) and societal laws such as property rights (enforced through coercion and violence) he differentiated the

\footnotetext{
${ }^{24}$ Andrew M. Koch, "Poststructuralism and the Epistemological Basis of Anarchism," Philosophy and the Social Sciences 23 (1993): 330.

25 "The Philosophical Roots of the Marx-Bakunin Debate", Ann Robertson, accessed 10/7/2012, http://www.marxists.org/reference/archive/bakunin/bio/robertson-ann.htm.
} 
authoritarianism inherent in state power and the authority of Reason and scientific thinking. It is this distinction that is crucial to the humanist, Enlightenment-inspired anarchist endeavor and key to differentiating it from its postanarchist successor.

Though critics of the Enlightenment have attacked the unquestioned authority of Reason (and its perceived harmful technocratic effects) they have not addressed the possibility of anarchism as a resolution to the problem of epistemic and ontological authority until recently. ${ }^{26}$ The story is, by now, well known. Beginning arguably with the Romantics and reaching its climax in postfoundationalist thought, the challenge to the hegemony of Reason in philosophy and the critique of idealism and humanism in the Enlightenment was manifested in an increasingly hostile reaction towards univocal or transcendent meaning, instrumental rationality, and scientific worldviews couched in the industrial and post-industrial processes of the $19^{\text {th }}$ and $20^{\text {th }}$ centuries. $^{27}$

Diverse thinkers such as Michel Foucault, Jean-François Lyotard, Jacques Derrida, Gilles Deleuze and Felix Guattari, among others, have argued that Western philosophical and especially Enlightenment considerations of Reason, including those prized by classical anarchists, are problematic because they both conceive of human

\footnotetext{
${ }^{26}$ See, for example, Max Horkheimer and Theodor Adorno, Dialectic of the Enlightenment: Philosophical Fragments. Ed., Gunzelin Schmid Noerr, trans., Edmund Jephcott (Stanford: Stanford University Press, 2002). Horkheimer and Adorno argue that the excesses of the Enlightenment faith in reason and its suspicion of anything which "does not conform to the standard of calculability and utility" led not only to the ambitious project of dominating nature but also the dominion of society, paving the way for the $20^{\text {th }}$ century's totalitarian regimes and the horrors of the Second World War (Horkheimer and Adorno, Dialectic, 3).

${ }^{27}$ See, for example, Horkheimer and Adorno, Dialectic of the Enlightenment; Michel Foucault, The Archeology of Knowledge, trans. A.M. Sheridan Smith (New York: Pantheon Books, 1972); as well as Fredric Jameson, Postmodernism, or, The Cultural Logic of Late Capitalism (Durham: Duke University Press, 1991) for an account of how these intellectual movements are situated in the increasing technocratic tendencies, instrumentalism, and frenetic dizziness of the $19^{\text {th }}$ and $20^{\text {th }}$ centuries.
} 
understanding as paradigmatically Reason-based and understand human liberation as a uniform progress towards the flourishing of Reason. They considered the exaltation of Reason as the "rationalization of coercion" (discipline in Foucault) and dismissed the project of truth-seeking as a misguided endeavor that endangered the independence of mind and autonomy central to critical inquiry. They saw the idea of progress as a "strategy of repression" and while, at times, relishing the anti-establishment spirit of the Enlightenment, these thinkers criticized what they saw as domination in the form of universalizing tendencies and "meta-narratives" of modernity. ${ }^{28}$

Like the classical anarchists generally, these thinkers were vehemently antihierarchical and anti-authoritarian. They were concerned about how power structures, relations of domination, and conceptual universality sustained hierarchy and arbitrary authority. These postfoundational philosophies aimed at a "profound destabilization" of authoritative "cognitive boundaries and frameworks" in challenging the hitherto lauded ideal of Reason. ${ }^{29}$ More generally, the postfoundational philosophies as a whole engage in a "fundamental questioning of the grand ideals and universal discourses that had defined our social, political and cultural reality since the Enlightenment."30

\footnotetext{
${ }^{28}$ Pierre Saint-Amand and Sophie Hawkes, "Contingency and the Enlightenment", in SubStance, Vol.26, No.2, Issue 83: An Ecology of Knowledge: Michael Serres: A Special Issue (1997: 96. For a critique of the "meta-narratives" in modernity see Jean-Francois Lyotard, The Postmodern Condition: A Report on Knowledge (Minneapolis: University of Minnesota Press, 1984).

${ }^{29}$ Fred Dallmayr, "The Politics of Non-Identity: Adorno, Postmodernism - And Edward Said", Political Theory, Vol. 25 No. 1, (February 1997): 33.

${ }^{30}$ Saul Newman, Unstable Universalities: Poststructuralism and Radical Politics (Manchester: Manchester University Press, 2008).
} 
For all the anti-authoritarian sentiment evident in postfoundational thought, what is noticeably absent is an accompanying anti-authoritarian political project that embraces anarchist values. ${ }^{31}$ That is, positions that characterized, among other things, the privileging of Reason as "politically undesirable and philosophically impossible" seemed to avoid the quintessentially anti-authoritarian anarchist tradition. ${ }^{32}$ This scholarship (especially the work of Todd May, Lewis Call, and Saul Newman) has stressed the need to reinterpret classical anarchist themes in light of postfoundationalism's ontoepistemological concerns. This scholarship seeks to address this aspect of anarchist thought by interrogating issues of hierarchy, arbitrary authority, and representationalism in classical anarchist ontology and epistemology.

While traditionally anarchists have challenged the idea that representative, ostensibly democratic, government is just, the anarchist critique is now expanded to include an interrogation of not only how our political interests are represented but also how we are categorized and characterized in ontological and epistemological terms. Contemporary postfoundational anarchist theory recognizes a distinction between perceived objects (be they modes of power and subjugation or even ourselves) and the ideas of those same objects occasioned by our perception of them. In the same way that Kropotkin in Words of a Rebel recognized that representative government is the protector of privilege and not the guarantor of democracy or our interests, postfoundational

\footnotetext{
${ }^{31}$ Postfoundational political arguments like these can be found in Richard Rorty's, Contingency, Irony, Solidarity and Essays on Heidegger and Others which accommodate anti-authoritarian or anti-metaphysical thought with liberalism, leaving the idea of the legitimate state and the capitalist firm unscathed.

${ }^{32}$ Ben Agger, "Critical Theory, Poststructuralism, Postmodernism," Annual Review of Sociology 17 (1991): 106.
} 
anarchists seek to dismantle the structures of ostensible representation that govern how we perceive ourselves and our world. ${ }^{33}$

These postanarchists extend the classical anarchist rejection of hierarchy, arbitrary authority, and representationalism to the classical anarchist reliance on Reason as a tool and byproduct of justice in the socio-cultural, economic, and political realms. Anarchism, in a sense, is turned on itself to question the legitimacy of a Reason-based and Enlightenment-inspired anarchist ontology and epistemology. ${ }^{34}$ In other words, in paving the way for a society that truly embraces classical anarchist principles and rejects arbitrary authority, hierarchy, and representation, Reason itself has become the object of critique.

This recent anarchist scholarship takes its inspiration from Friedrich Nietzsche and Max Stirner, two notable anti-essentialist, anti-metaphysical thinkers as well as the postfoundationalist projects they inspired more generally. Lewis Call notes that

\footnotetext{
${ }^{33}$ In Words of a Rebel Kropotkin notes that representative government is the protector of privilege and not the guarantor of democracy or our interests. See Kropotkin's commentary on representative government in Words of a Rebel available at "Kropotkin: Representative Government," Peter Kropotkin, accessed July 27, 2016, https://robertgraham.wordpress.com/2012/12/24/kropotkin-representative-government/

${ }^{34}$ I make the distinction between justification of Reason-based approaches to political organization and legitimacy of the same as noted in A. John Simmons, "Justification and Legitimacy", Ethics 109: 4 (July 1999): 739-771, where he argues that justification is the idea that we have reason to follow the direction or allow the authority of the state (say for material benefit or social cohesion) while legitimacy refers to the "exclusive moral right of an institution to impose on some group of persons, and to enforce those duties coercively" independent of any justificatory considerations (Simmons, 769). I think that the conflation of justificatory mechanisms and principles of legitimation obscure the implicit framework of arbitrary authority postfoundational philosophers seek to combat in ontology and epistemology (and should combat in the realm of politics). That is, where it may be conceivable that authority would fail to be arbitrary once it is justified, it can still be considered illegitimate. It is, by and large, the illegitimate nature of authority that I will be addressing in the privileging of Reason in anarchist ontology and epistemology.
} 
His [Nietzsche's] philosophy is thus anarchistic in the strong sense of the term: it includes important elements of an anarchistic politics, but (more importantly) it also contains an anarchy of thought. Nietzsche's writing attacks hierarchy not only at the political level but at the philosophical level as well, undermining the very foundations of the deeply entrenched metaphysics of domination upon which the West as come to rely. ${ }^{35}$

Likewise,

All our beliefs are dismissed by Stirner as so many ideological abstractions, 'spooks', 'fixed ideas': our faith in rationality is shown to be no less superstitious than faith in the most obfuscating of religions; Man is simply God reinvented; secular institutions and discourses are alive with spectres of Christianity; universalism is spoken from a particular position of power. ${ }^{36}$

According to postanarchists, it is this thinking about hierarchy in every realm-including the intellectual—which distinguishes these recent anarchist thinkers from the classical anarchists. According to Newman and other postanarchists, classical anarchists still prized hierarchy in the realm of the intellect, a hierarchy that undermines the anarchist project. According to Call, "classical anarchism is haunted by a rationalist semiotics which seriously limits its radical potential. ${ }^{37}$ The postanarchist project employs key themes in Stirner and Nietzsche, as well as prominent postmodern and poststructuralist

\footnotetext{
${ }^{35}$ Lewis Call, Postmodern Anarchism (Lanham, MD: Lexington Books, 2003), 2.

${ }^{36}$ Saul Newman, ed., Max Stirner (New York: Palgrave Macmillan, 2010), 1.

${ }^{37}$ Call, Postmodern Anarchism, 16.
} 
thinkers, to address issues of hierarchy and arbitrary authority in questions of epistemological and ontological import. Call, Newman, May and others interpret the role of postfoundationalist thought as dissecting and debunking the privileged position of Reason and other essentialist Enlightenment inspired notions in anarchist political philosophy.

This approach, to some anarchist thinkers, is an ethical call. Todd May notes that the "first ethical principle to which poststructuralism is committed is that practices of representing others to themselves - either in who they are or in what they want - ought, as much as possible, to be avoided. ${ }^{, 38}$ In identifying the inherent authoritarianism of an accompanying representational essentialist view of the individual, anarchists like May note the dangers in acting or resisting based on authoritarian structures even in the realm of the intellect. Newman notes “....resistance must not refer to essentialist foundations if it is to avoid reaffirming domination. ${ }^{, 39}$ He concludes that

...anarchism's pure place of resistance against power, its uncontaminated point of departure - the essential human subject and its related discourses of morality and rationality - was found to be somewhat impure, and contaminated by power. The place of resistance was, on the contrary, a place of power and domination. The only trouble with this was that, while it exposed the authoritarian potential within anarchism and indeed any revolutionary philosophy which was based on

\footnotetext{
${ }^{38}$ Todd May, The Political Philosophy of Poststructuralist Anarchism (University Park, PA: The Pennsylvania State University Press, 1994), 130.

${ }^{39}$ Saul Newman, From Bakunin to Lacan: Anti-Authoritarianism and the Dislocation of Power (Lanham, MD: Lexington Books, 2001), 10.
} 
essentialist ideas, it deprived the anti-authoritarian project of its own point of resistance. $^{40}$

Indeed, postfoundationalism carries an anti-authoritarian ethos that complements anarchist political, economic, and socio-cultural commitments. Recognizing the relationship between the anti-authoritarian spirit in postfoundationalism, Nietzsche's and Stirner's epistemology and ontology, and classical anarchist concerns is central to tracing the "logical" extent of anarchist thought. In other words, in striving to remain consistent, applying classical anarchist principles to all realms of life (specifically the realm of the intellect), we are forced to interrogate the epistemological and ontological foundations of classical anarchism in ways the classical anarchists supposedly did not consider. Indeed, as Newman notes "Anarchism is animated by a living, breathing 'spirit' of anarchy that disturbs its static foundations and fixed identities. Postanarchism reveals this joyous moment of anarchy within anarchism..."41

In presuming to carry the mantle of classical anarchist values, postanarchists move towards a pluralistic anarchism by attempting to embrace an anti-authoritarianism of the intellect without falling into any rigid ideological or philosophical contours. Such contours would limit the radical potential of this contemporary strand of anarchist thought while undermining the liberating ethos of anarchism itself. In other words, according to postanarchists, there is no single Archimedean point from which anarchist thought and practice hinges but rather a confluence of opportunities to resist and innumerable points at which to apply anarchist critiques. In resisting classical anarchist

\footnotetext{
${ }^{40}$ Newman, From Bakunin to Lacan, 159.

${ }^{41}$ Saul Newman, The Politics of Postanarchism (Edinburgh: Edinburgh University Press, 2011), 182.
} 
authoritarianism in the realm of the intellect, postanarchists seek to attune classical anarchist thought with what they see as anarchist values.

While accepting that this recent anarchist literature embraces the spirit of classical anarchist ideas I will question the viability of such postanarchist interpretations of classical anarchist themes and assess its implications for anarchist political thought more generally. The postanarchist endeavor is susceptible to the accusation that it becomes an exercise in incoherence when it decries the use of Reason in the construction of any radical (or otherwise political) project yet engages in ostensibly Reason-based analysis when examining the pitfalls of essentialist vocabularies, arbitrary methodological hierarchies, and unwarranted conceptual limitations. The question becomes: How can postanarchists coherently critique the classical anarchist reliance on Reason without relying on Reason itself in articulating that critique?

The postanarchist argument is reminiscent of Adorno's endeavor in Negative Dialectics that Habermas critiques, where

Philosophical critique... is unrelentingly negative and refuses to reconcile itself to the positive for that would merely produce a new delusion. To do so is actually to miscarry the thought-process since the dynamic aspect of thought lies in its power to explode the illusion of identity: 'Nonidentity is the secret telos of identification, that which is to be rescued in it; the mistake of traditional theory is that it holds identity as its goal.' 42

\footnotetext{
${ }^{42}$ Morris, "Performative Contradiction," 756. See also, Theodor W. Adorno, Negative Dialectics, trans. E.B. Ashton (New York: Continuum International Publishing Group, 1973).
} 
Habermas accuses Adorno of relying on the "tools" of Reason in denouncing the "delusion" of the same. Critique here is "purposive-rational because it uses concepts (since one cannot think without concepts), but is also more than this because it is aware that the very instrumental nature of concepts is false - they do not measure up to their own concept. Yet the critic nevertheless 'thinks' and 'criticizes'.,43

This inescapable feature of philosophical critique is, according to Habermas, central to modernity in that in creating its "normativity out of itself" it "sees itself cast back upon itself without any possibility of escape. ${ }^{.44}$ A Reason-based critique is both the result of and the impetus for this normativity. Though Adorno clearly distinguishes between the dangers of Reason (especially instrumental reason) and reasons in argumentation that underlie philosophical critique, Habermas argues such a distinction is nonsensical in that philosophical critique is inherently limited to the horizon of this understanding of Modernity and that Reason itself is redeemed even if engaged in a critique of itself. ${ }^{45}$

The compulsion to "avoid" or "resolve" the aporia of Reason in anti-authoritarian thought (that is, either to invent a new understanding of the aporia independent of Reason or to seek to overcome it with novel intellectual tools that exclude Reason) is absent in the postanarchists. The postanarchists do not argue for a need to overcome the aporia of

\footnotetext{
${ }^{43}$ Morris, "Performative Contradiction," 756.

${ }^{44}$ Jurgen Habermas, The Philosophical Discourse of Modernity, trans. Frederick G. Lawrence (Cambridge: MIT Press, 2000), 7.

${ }^{45}$ For a stinging critique of instrumental reason and the Enlightenment that inspired it see Adorno and Horkheimer, Dialectic of the Enlightenment. For his understanding of modernity see Habermas, The Philosophical Discourse of Modernity, Ch. 1.
} 
Reason sketched by Habermas but rather critique it and dismiss their own supposedly aporetic endeavor. Taking the Habermasian critique into consideration, I will echo Martin Morris and pay particular attention to the distinction between the postanarchist argument (and postfoundationalist endeavor, generally) being performatively contradictory precisely in making a point (namely rejecting the hopeless or aporetic nature of the postanarchist critique) and the argument remaining intelligible in its reasoning, therefore remaining consistent and coherent. ${ }^{46}$ Moreover, I will point to how these approaches contribute to an understanding of anarchist anti-intellectualism and sketch alternative ways of approaching the question of freedom in the anarchist tradition.

\section{Chapter Outline}

Chapter one will critically consider the so-called classical anarchist tradition as quintessential children of the Enlightenment. I will endeavor to unpack the veracity of this reading of the so-called classical anarchists and highlight a nuanced understanding of Reason, the celebration of science, and "foundationalisms" of all sorts in these same thinkers. My hope is that such a critical interrogation of the classical anarchists will make us re-think the popular characterization of anarchist ontology, epistemology, and reliance on Reason. This chapter will briefly highlight the importance of an idealized Reason in

\footnotetext{
${ }^{46}$ See, Morris, "Performative Contradiction," 735-760.
} 
the history of modern philosophy as well as survey its trajectory in the quintessentially anti-authoritarian anarchist political project. I will also interrogate the necessity for a consistent anti-authoritarianism in anarchist thought and will review challenges to the Enlightenment faith in Reason in epistemology and ontology as well as suggest ways of proceeding coherently with an anti-authoritarian onto-epistemological anarchist project.

Chapter two will explore, in more detail, the attitudes of William Godwin and Pierre Joseph Proudhon towards Enlightenment values, Modernity more generally, and consider how their thought contributes to anarchist anti-intellectualism. Godwin and Proudhon generally deferred to the authority of Reason yet were ambiguous in their treatment of foundational ideals like human nature and transcendent truth. While they both celebrated Reason they recognized its limitations and even dangers. While they both believed in the emancipatory potential of the Enlightenment they also challenged the framework that grounded it. Unlike their anarchist counterparts, Bakunin and Kropotkin, they both gradually shifted towards more critical stances on authoritative accounts of Reason and auxiliary notions like human nature and science.

Chapter three will consider how Mikhail Bakunin and Peter Kropotkin celebrated the scientific method's ability to decipher reality in such a way that would expedite anarchist revolutions. Yet, while praising the liberating aspects of science (and the usually accompanying ideal of Reason) they diagnosed an overreliance on these same ideals and recognized the hierarchically institutionalized forms of scientific discovery, the univocity of rational thought, and the pernicious division of intellectual from manual labor that usually accompanied such an uncritical lauding on Reason and science. Instead, 
they emphasized spontaneity and improvisation. They promoted a healthy skepticism of "intellectual authority" as urgently as they challenged the legitimacy of the state and other forms of institutionalized hierarchy.

Chapter four will examine Max Stirner's and Friedrich Nietzsche's challenges to metaphysics and epistemology and their connection to anti-authoritarian thought (especially the anarchist tradition and recent developments in postfoundational anarchist theory). In part, my purpose is to stress the importance of both Stirner and Nietzsche in thinking through what anarchist anti-intellectualism looks like. Moreover, in doing so, I hope to facilitate new ways in thinking about domination and authority in the realm of the intellect and interrogate how such an anti-intellectualism can point towards what anarchists like Stirner considered thinking "freely."

In my concluding chapter, I frame my reading of anarchist anti-intellectualism in terms of contemporary philosophical attempts to, as anarchists have termed it, be "without adjectives." I do so by assessing three main approaches (Wittgensteinian, Feyerabendian, and Rortyean) in order to, as Svetlana Boym put it, think "without bannisters." In doing so, I attempt to "redescribe" anarchist anti-intellectualism as a kind of ironism made public and hope to further what anarchists would consider thinking "freely." 


\section{Chapter 1}

\section{Contextualizing and Theorizing Anarchist Anti-Intellectualism}

In the usual reading of the classical anarchists we encounter two equally forceful tendencies in their exaltation of Reason. ${ }^{47}$ On the one hand, we see an indefatigable faith in the idea that Reason propels progress (and itself is progressively realized). On the other hand, we see the idea that Reason should be unimpeded in its exercise. The latter tendency is possible only with the progress of Reason itself. In other words, it is only through the unimpeded exercise of Reason (that is, an exercise unencumbered by arbitrary exercises of authority by government, private concentrations of wealth, or the church) that we are able to eliminate those very same arbitrary exercises of authority.

Such a reading presents the reader with a problem. It seems impossible to grasp the aspirations of the classical anarchists without admitting to their circular reasoning. We see a considerable logical obstacle to their lauding of Reason, namely, in that its unquestioned authority lies in demolishing all other forms of authority (in the social, economic, and political realms) which itself requires an idealized Reason only possible when this very same authority is absent.

In overcoming this apparently circular reasoning, a glaring inconsistency comes to the fore. We see a consistent anti-authoritarianism in the social, economic, and

\footnotetext{
${ }_{47}$ Among the classical anarchists I include William Godwin, Pierre Joseph Proudhon, Mikhail Bakunin, Peter Kropotkin and their immediate followers, among them Emma Goldman, Rudolph Rocker, et al. According to some critics of the classical anarchist tradition (Todd May, Lewis Call, Saul Newman, et al.), what is notable about these thinkers is that they idealize Reason (which I capitalize to distinguish it from the more commonplace notion of the faculty of reason or the employment of reasons in argumentation) in a way that is consistent with the thrust of the Enlightenment tradition and ignores the authority inherent in prizing Reason itself as an emancipatory means and end.
} 
political realms subdued by the unquestioned authority of Reason itself. Indeed, this allows the classical anarchists to, on the one hand, consistently decry the exercise of arbitrary authority by the state, concentrations of private power, and the church, and, on the other hand, blame the faulty realization of Reason as an ideal.

In this chapter, I will challenge this reading of the classical anarchists and highlight a nuanced understanding of Reason in these same thinkers. This critical interrogation of the classical anarchists will make us re-think the popular characterization of anarchist ontology, epistemology, and their reliance on Reason. This chapter will briefly highlight the importance of an idealized Reason in the history of modern philosophy as well as survey its trajectory in the quintessentially anti-authoritarian classical anarchist political project. I will also interrogate the necessity for a consistent anti-authoritarianism in anarchist thought and will review challenges to the Enlightenment faith in Reason in epistemology and ontology as well as suggest ways of

proceeding coherently with a consistent anti-authoritarian onto-epistemological anarchist project.

\section{Classical Anarchists as Children of the Enlightenment}

Contemporary postfoundationalist critics of the anarchist tradition see the emergence of classical anarchist anti-authoritarianism as couched in the heritage of the Enlightenment that lauded, above all else, Reason's potential. They claim that, in understanding the Enlightenment as “man's emergence from his self-incurred 
immaturity" $" 48$ or as an escape from "a certain state or will that makes us accept someone else's authority to lead us in areas where the use of reason is called for," ${ }^{\text {,4 }}$ the classical anarchists echoed Enlightenment thinkers in relying on an unquestioned authority of Reason to guide societal progress. Indeed, the classical anarchists sought to harness the power of Reason to overcome the stifling effects of concentrated state power, wealth, and industrialization during the $18^{\text {th }}$ and $19^{\text {th }}$ centuries. ${ }^{50}$

Nevertheless, there are mixed interpretations of the nature of Enlightenment thinking and the classical anarchists who garnered inspiration from it. The Enlightenment is not considered a monolithic tradition nor is it understood as wholly liberating. Some see the Enlightenment as a liberating intellectual movement, while others see it flirting with dangerous totalitarian tendencies. ${ }^{51}$ The positive aspects attributed to it as a liberating intellectual movement tend to echo the ideals of a perpetual questioning of faith, tradition, and authority as well as a lauding of Reason. However, accompanying these views are recent backlashes that point to dangerous totalitarian

\footnotetext{
${ }^{48}$ H.S. Reiss, ed., Kant: Political Writings (Cambridge: Cambridge University Press, 1991), 54.

${ }^{49}$ Paul Ranibow, ed., The Foucault Reader (New York: Pantheon Books, 1984), 34.

${ }^{50}$ See Saul Newman, From Bakunin to Lacan: Anti-Authoritarianism and the Dislocation of Power. (Lanham, MD: Lexington Books, 2001); Saul Newman, Unstable Universalities: Poststructuralism and radical politics (Manchester: Manchester University Press, 2007); Saul Newman, The Politics of Postanarchism (Edinburgh: Edinburgh University Press, 2011); Saul Newman, ed., Max Stirner (United Kingdom: Palgrave Macmillan, 2011); Todd May, The Political Philosophy of Poststructuralist Anarchism (University Park, PA: The Pennsylvania State University Press, 1994); Lewis Call, Postmodern Anarchism. (Lanham, MD: Lexington Books, 2003).

${ }^{51}$ Max Horkheimer and Theodor W. Adorno, trans. Edmund Jephcott, Dialectic of the Enlightenment: Philosophical Fragments (Redwood City, CA: Stanford University Press, 2002).
} 
tendencies sustained by a uniform conception of human nature and a "rational absolutism" that seems to promise the "secret of the philosopher's stone.",52

This faith in the epistemological, ontological, and social authority of Reason seemed to mutually reinforce the political ideal of equality shared by many Enlightenment thinkers. Political equality was rooted in a philosophical and political anthropology that encouraged us to exercise a common faculty of reason to overcome the traditional hierarchical political and social orders of the middle ages. Overcoming this hierarchy required an enthusiasm for both an idealized conception of Reason and the idea of progress.

The great enthusiasm for Reason that emerged during the Enlightenment encompassed fervor for both the deductive rationalism of the continental $\operatorname{tradition}^{53}$ as well as a newfound faith in sense experience via the philosophical systems of British empiricists. ${ }^{54}$ Crowning the Enlightenment was Kant's critique of Reason that categorized and clearly delineated the limits of our most esteemed faculty. ${ }^{55}$ Indeed, beginning in the late $17^{\text {th }}$ and early $18^{\text {th }}$ century we saw a "general process of rationalization and secularization" that "eradicated magic and belief in the supernatural from Europe's intellectual culture" that supplanted theology's hegemony in the world of

\footnotetext{
52 David Collings, "The Romance of the Impossible: William Godwin and the Empty Place of Reason", English Literary History (Volume 70, Number 3 Fall 2003): 849.

${ }^{53}$ Among the Continental Rationalists are Rene Descartes, Gottfried Wilhelm Leibniz, and Baruch Spinoza.

${ }^{54}$ Among the British empiricists are John Locke and David Hume.

${ }^{55}$ Most notably, Kant recognized our inability to access or conceive things-in-themselves, or the noumenal.
} 
study. ${ }^{56}$ In Western Europe, theology itself became increasingly self-critical and through a process of reformation and counter-reformation that appeased the growing thirst for critical attitudes in every realm of life.

Intellectual life became increasingly de-centered, local knowledge was prioritized over absolutist epistemologies, traditions of political authority were transformed, and modes of economic life began to be questioned along libertarian lines. ${ }^{57}$ These all converged with a plethora of radical ideas that were "nurtured within an urban milieu characterized by exceptional fluidity of social relations and movement between social strata, features which correspond directly to the freer, more flexible intellectual framework which emerged." ${ }^{, 58}$

The reverberations of the intellectual crises of the Enlightenment were felt just as forcefully in the politics and sociology of class. This new intellectual culture both fostered and was cultivated by the "advent of new associations and locations with no fixed rules of access, which ... provided a social space not specific to any one class.",59

The Enlightenment inspired and was generated by a sort of intellectual meritocracy, as envisioned by some of its key participants such as Lord Shaftsbury, where society would be ruled not by the traditional landed elite but rather a "new kind of

\footnotetext{
${ }^{56}$ Jonathan Israel, Radical Enlightenment: Philosophy and the Making of Modernity 1650-1750 (Oxford: Oxford University Press, 2001), 4.

${ }^{57}$ For a good history see Peter Marshall, Demanding the Impossible: A History of Anarchism (Oakland: PM Press, 2010). See also, George Woodcock, Anarchism: A History of Libertarian Ideas and Movements (Cleveland: Meridian Books, 1962).

${ }^{58}$ Israel, Radical Enlightenment, 59.

${ }^{59}$ Ibid, 60.
} 
élite of affairs and ideas - an élite of the cultured, well-meaning, and gentlemanly." Moreover, the movement would claim liberty as a "political and social condition" and not just a narrow constitutional affair as defined by the 'Glorious Revolution'. Instead, it was envisioned as a liberty "defined by debate, criticism, and cultural exchange."

Though there were innumerable debates among these schools (as well as various schools of skeptics, subjectivists, and deists of all sorts), the underlying and edifying theme of the Enlightenment was a reliance on private judgment guided by ones reason. The emerging intellectuals of Enlightenment Europe hoped that private judgment would stand hegemonic over intellectual pursuits. This intellectual hegemony would encompass a belief that all modes of inquiry should rely, as little as possible, on traditional sources of both knowledge and power. The church and the state were seen as sources of arbitrary authority that impeded the pure analytical and investigatory potential of our cognitive faculties.

In addition to a lauding of Reason, the idea of progress is also omnipresent in Enlightenment thought as well as the classical anarchists who point to the expanding quality of our intellectual endeavors. Indeed, the classical anarchists believed and hoped for progress in both our moral capacities as well as our rational and scientific pursuits. This notion of progress in the classical anarchists reflects the firm basis of their thought in the Enlightenment tradition. But, like the classical anarchists, the Enlightenment tradition is itself nuanced when it comes to the idea of progress. There are strong

\footnotetext{
${ }^{60}$ Ibid, 67. See also, Jürgen Habermas, The Structural Transformation of the Public Sphere: An Inquiry into a Category of Bourgeois Society, trans. Thomas Burger (Cambridge: MIT Press, 1991).
} 
elements of a belief in progress as well as a healthy skepticism (often contradictory) towards the ideal of Reason and the notion of inevitable progress.

There are many instances of a notion of progress accompanying our increasing ability to, as Descartes put it, master and possess nature by harnessing the power of Reason. Nevertheless, advances in science and technology seemed to point to a historicintellectual end-point thinkers in the Hegelian tradition recognized as the "end of history." ${ }^{61}$ In any case, this spirit of progress in the post-Enlightenment frenzy over the limitless potential of Reason marched intellectual and social life towards a vague sense of completion.

However, it would be unfair to characterize Enlightenment thinkers as wholly worshipping at the altar of Reason. While Hume questioned the value of induction and stressed the non-rational aspects of cognition, like sentimentalism, and Kant highlighted the inaccessibility of the noumenal ${ }^{62}$, Giambattista Vico, Johann Georg Hamann, and Johann Gottfried Herder stressed the historical nuance of "rival values within systems" and "different value systems with divergent backgrounds" that posses "their own independent validity and authenticity." ${ }^{, 3}$

Even quintessential children of the Enlightenment like Proudhon had their doubts about the hegemony of Reason in promoting progress. In a letter to Marx, Proudhon

\footnotetext{
${ }^{61}$ See Francis Fukuyama, The End of History and the Last Man (New York: Simon and Schuster, 2006).

${ }^{62}$ See David Hume, A Treatise of Human Nature, ed. David Fate Norton and Mary J. Norton (Oxford; New York: Oxford University Press, 2000); Immanuel Kant, Critique of Pure Reason, trans. Norman Kemp Smith (New York: St. Martin's Press, 1965).

${ }^{63}$ Isaiah Berlin, Three Critics of the Enlightenment: Vico, Hamann, Herder (Princeton: Princeton University Press, 2013), xiv.
} 
warned of the need to "...not become the leaders of a new intolerance." He continued, “...let us not pose as apostles of a new religion, be it the religion of logic, the religion of reason. We should welcome, encourage all protests; denounce all exclusions, all mysticisms; let us never see a question as exhausted, and when we will have made our final argument, let us, if needed, begin again with eloquence and irony."

Proudhon's message of tolerance resonates with contemporary critics of the Enlightenment tradition. It echoes the concern over the possibility of domination even in the sphere of the intellect. Predating postfoundationalist critiques of essentialism, representation, and universalism, Proudhon appealed to a fundamental anarchist antiauthoritarian sentiment. Indeed, the classical anarchist tradition is not so easily interpreted as simply “essentialist.” According to Cohn,

The notion that classical anarchist theory presupposes an "essentialist foundation" outside of the flux of history is also open to challenge. Rather, in refusing dualisms of matter and thought, bodies and souls, nineteenth century anarchists locate their theory within a process of development that is at once natural and historical. The visible universe does not ask for a transcendental supplement, but is the source of its own autopoietic and self-transformative creativity. ${ }^{65}$

Indeed, his fellow anarchists eventually accompanied Proudhon in his wariness of the totalitarian potential of Reason. However, their critical embrace of Reason and critique

\footnotetext{
${ }^{64}$ Farès el-Dahdah, Pierre-Joseph Proudhon "Letter from Pierre-Joseph Proudhon to Karl Marx", Assemblage No 41 (April, 2000): 21.

${ }^{65}$ Jesse Cohn, Anarchism and the Crisis of Representation: Hermeneutics, Aesthetics, Politics (Selinsgrove, PA: Susquehanna University Press, 2006), 73.
} 
of intellectualism was often sporadic and inconsistent. Often times, Proudhon himself seemingly contradicted this concern by celebrating the emancipatory potential of Reason and reiterating accompanying "essentialist" and "universalizing" concepts like truth, progress, and human nature. He, along with his fellow classical anarchists, continued the long tradition of privileging our uniquely human faculty of reason albeit not unquestioningly.

\section{On the Need for Consistent Anti-Authoritarianism}

Anarchism, like any set of values, prizes some ideas more than others. Above all, we can say the classical anarchists prized a society that cherished individual liberty. While differences abound as to how to achieve such a society (e.g., whether to have communal ownership of the means of production - as in Kropotkin and Bakunin - or ensure access to private property - as in Godwin, Proudhon, and Max Stirner was a key question) a thorough regard for individual aims and individuality remains constant throughout all classical anarchist thinkers.

It can be argued that the main impetus behind the classical anarchist faith in Reason and private judgment, when present, is an undeniable embrace of individuality and a rejection of representation (which is premised on a denial of our uniqueness that cannot be represented). ${ }^{66}$ It is the drive towards exercising individuality through autonomy that forges the anarchist individualist perspective that relies on the ideal of Reason. The tension arises when such a privileging of Reason hampers rather than

\footnotetext{
${ }^{66}$ See Max Stirner, The Ego and its Own, ed. David Leopold (Cambridge: Cambridge University Press, 1995).
} 
facilitates this individual freedom. It is such an obstacle to individual freedom that postanarchists claim is at the heart of their postfoundationalist critique of classical anarchism.

According to L. Susan Brown, this individualism is an offshoot of the individualism of classical liberalism. Responding to Macpherson's interpretation of the liberal tradition, in which he posits its underpinning in "possessive individualism," she identifies two competing strains of individuality in this understanding: on the one hand an instrumental individualism that entails a right to both real property and property in your person, and existential individualism which seeks freedom independently of any ownership of property. She notes that these two strains conflict. It is in seeking a resolution to these two competing strains, identified by Brown, that the postanarchists largely base their endeavor. Postanarchists recognize the "radical commitment to individual freedom while rejecting liberalism's competitive property relations" as well as embrace the need to overcome the "totalizing" nature of privileged Reason.

However, as we have seen, the premise of the "totalizing" onto-epistemological foundation of the classical anarchists can be easily doubted. There is plenty of textual evidence to indicate that the classical anarchists were more nuanced than the postanarchists make them out to be. The question then becomes whether a more explicit framework (as the classical anarchists are often unclear, vague, and even contradictory when it comes to their analysis of Reason) is needed to sketch what anti-authoritarianism in ontology and epistemology would look like for an anarchist. 


\section{Classical Anarchism and Postfoundationalist Anti-Authoritarianism}

According to Brown, the ontological framework characteristic of anarchists is shared by another philosophical tradition usually not associated with essentialist renderings of the human condition. She notes,

Human individuals, for the anarchist, are best suited to decide for themselves how to run the affairs of their own lives; they are best served when left unrestrained by authority and unhampered by relationships of domination. The ontological basis for these beliefs is an understanding that individuals are free and responsible agents who are fit to determine their own development. This ontology is shared at least in part by a number of philosophies; however, it has been most fully developed by the existentialists. ${ }^{67}$

The existentialists, like the anarchists, perhaps best considered as fellow travelers and not disciples of any specific thinker or creed, represent, for Brown, an ontological lineage that spurns essentialist renderings of human nature and other familiar "foundationalisms."

As we have seen, many of the classical anarchists approached the question of human nature and the authority of Reason with both conviction and skepticism. However, key postanarchist thinkers endeavor to highlight the foundationalist (and in their view authoritarian) tendencies underlying the classical anarchist project. Contemporary anarchist scholars like Saul Newman question the classical anarchist's “ontological and epistemological foundations." The onto-epistemological character of

${ }^{67}$ L. Susan Brown, The Politics of Individualism (Montreal: Black Rose Books, 2003), 2. 
classical anarchist thought is conceived as centering on an essentialist view of human nature that expounds the idea of a rational and generally progressive being as well as lauds the ideal of Reason.

Newman notes that consistent anarchist anti-authoritarians should embrace the postfoundationalist critique of epistemology and ontology and apply it to the social and political realms. To do this we "should adopt, with Lyotard, a degree of skepticism towards metanarratives." That is, "subject to closer critical scrutiny the idea that there are universal moral and rational perspectives, or that there is a certain dialectical movement of historical forces that determines social relations." We should also, "abandon the notion of essential identities" and "place a certain emphasis on the role of language and discourse in constituting social relations, practices, and identities." And, lastly, postanarchists should "accept the Foucauldian insight that power is constitutive (rather than simply repressive) and that it is more pervasive than we had perhaps imagined." ${ }^{.68}$ Newman and other postfoundationalist anarchists insist that such skepticism towards metanarratives, essentialism, and a strictly repressive view of power limit the anarchist imaginary in ways that neglect examples of illegitimate epistemological and ontological authority.

However, generally absent from the postanarchist critique is an acknowledgement that the classical anarchists took care to recognize the authoritarian potential of an unquestioned Reason and, for the most part, rejected monolithic understandings of human nature. The seeds of a critical reflection on a "rational absolutism" are already present in

\footnotetext{
${ }^{68}$ Saul Newman, The Politics of Postanarchism (Edinburgh: Edinburgh University Press, 2011), 140-1.
} 
Godwin's literary works in which he exposes the "conceptual violence" implicit in such an adulation of Reason. ${ }^{69}$ According to David Collins, in Things as they Are; or, The Adventures of Caleb Williams and St. Leon: A Tale of the Sixteenth Century, Godwin (of the classical anarchists, perhaps the most unapologetic champion of Reason) takes care to warn his audience of the dangers of an aspiration to omniscience or perfectibility. Indeed, in St. Leon Godwin challenges the notion of perfectibility and detached objectivity while couching his critique in a thorough undercutting of progressive modernity. Godwin's novels extoll the virtues of, what he called, private judgment, all the while acknowledging the impossibility of having that private judgment grasp reality in its entirety. ${ }^{70}$

Nevertheless, scholars like Brown acknowledge that classical anarchism would benefit from a postfoundationalist understanding of human nature. She notes, "The political philosophy of existentialism, with its rejection of a fixed human nature and its affirmation of humanity as freedom itself, offers anarchism a fluid conceptualization of human nature more in keeping with its individualist imperative.,71

The classical anarchists, though acknowledging the inherent diversity in individuals, still seemingly relied on an Enlightenment framework that, at least in part, limited freedom-seeking to the social, political, and economic realms, leaving musings of freedom in the realm of the intellect largely untouched. While Godwin and others hinted a the futility of sketching an ideal of Reason or the hope for a perfect private judgment,

\footnotetext{
${ }^{69}$ Collings, 848 .

${ }^{70}$ Ibid, 849.

${ }^{71}$ Brown, 153.
} 
the key to a free society remained rational individuals acting out their natures (social or otherwise).

\section{The Postanarchist Critique and Anarchist Anti-Intellectualism}

The postanarchist fusion of classical anarchist and postfoundationalist thought is an avenue that embraces the spirit of classical anarchist anti-authoritarianism in ontology and epistemology. Nevertheless, like other postfoundational philosophies it is susceptible to incoherence. The challenge that faces postanarchist criticism is the question of authority in that very critique. That is, can the postanarchist critique be contained within a coherent programmatic challenge to the authority of Reason and the conceptually limiting auxiliary notions that usually accompany it?

The postanarchist endeavor is susceptible to the accusation that it becomes an exercise in incoherence when it decries the use of Reason in the construction of any radical (or otherwise political) project yet engages in ostensibly Reason-based analysis when examining the pitfalls of an adulation of Reason, essentialist vocabularies, arbitrary methodological hierarchies, and unwarranted conceptual limitations. The question becomes, how can postanarchists coherently critique the classical anarchist reliance on Reason without relying on Reason itself in articulating that critique?

The story is by now familiar. While the postfoundationalists (Foucault, Lyotard, Derrida, et al.) often brazenly critiqued the onto-epistemological assumptions of modernity as authoritarian and limiting, others (especially Habermas) claimed that the possibilities for critique were already built into modernity itself and that attempting to 
circumvent such foundational assumptions was an exercise in incoherence. Feyerabend problematizes the Habermasian critique well. He notes,

Now- how can we possibly examine something we are using all the time? How can we analyse the terms in which we habitually express our most simple and straightforward observations, and reveal their pre-suppositions? How can we discover the kind of world we presuppose when proceeding as we do $?^{72}$

The Habermasian idea of "performative contradiction" claims that the postfoundational literature is unable to decry the lauding of Reason and the accompanying epistemological and ontological assumptions because they are nevertheless present in the critique itself. That is, Habermas claims that movements like postanarchism necessarily employ the very same devices they claim are unjustifiable or illegitimate in the application of anarchist values to epistemology and ontology.

According to Habermas there is no need to avoid the trappings of an authoritarian Reason or the accompanying onto-epistemological assumptions because they already reflect the auto-critical character of modernity. This inescapable feature of philosophical critique is, according to Habermas, central to modernity in that in creating its "normativity out of itself" it "sees itself cast back upon itself without any possibility of escape." ${ }^{, 73}$ A Reason-based critique is both the result of and the impetus for this normativity. According to Habermas, philosophical critique is inherently limited to the

\footnotetext{
${ }^{72}$ Paul Feyerabend, Against Method: Outline of an anarchistic theory of knowledge (London: Verso, 1978), 31.

${ }^{73}$ Jurgen Habermas, The Philosophical Discourse of Modernity, trans. Frederick G. Lawrence (Cambridge: MIT Press, 2000), 7.
} 
horizon of this understanding of Modernity and that Reason itself is redeemed even if engaged in a critique of itself. ${ }^{74}$

The compulsion to "avoid" or "resolve" the aporia of an authoritative Reason in anti-authoritarian thought (that is, to either invent a new understanding of the aporia independent of Reason or seeking to overcome it with novel intellectual tools that exclude Reason) is absent in the postanarchists. The postanarchists do not argue for a need to overcome the aporia of Reason sketched by Habermas but rather critique it and dismiss their own supposedly aporetic endeavor. In other words, postanarchists largely talk past this Habermasian critique. So, how can we question the postanarchist endeavor along Habermasian lines while sketching a way to overcome the seemingly arbitrary authority of Reason pointed to by postanarchists?

Perhaps a better way to approach the problem of Reason and consistent antiauthoritarianism would be to interrogate an alternative framework by which to understand the critique. We could do so by incorporating Ludwig Wittgenstein's later philosophy. ${ }^{75}$ Wittgenstein moves us away from a representationalist, interpretational, or correspondence-based epistemological paradigm to a view focused on "obeying rules" or simply a "deed-based" approach to understanding. Admitting to the force of the postanarchist critique we can still hope to overcome its "performative contradiction" by bridging the critique with a procedural logic by employing key ideas in Wittgenstein, such as "knowing how to go on" and "rule following."

\footnotetext{
${ }^{74}$ For a stinging critique of instrumental reason and the Enlightenment that inspired it see Adorno and Horkheimer, Dialectic of the Enlightenment. For his understanding of modernity see Habermas, The Philosophical Discourse of Modernity, Ch. 1.

${ }^{75}$ Mainly I am referring to his work in Philosophical Investigations.
} 
"Knowing how to go on" is understood here as the idea that language has a multiplicity of applications which vary according to community and where understanding is largely based on practice. It is actually applying how one conceives of rules, attitudes, principles, and orientations and, in a way, internalizing them so as to not figure it necessary to hold some external marker as your guide. ${ }^{76}$ That is, rather than point to a fixed meaning, Wittgenstein notes the plurality of meanings and the need for practice as the ultimate measure of meaning. In this sense, understanding is always part of an activity. Indeed, it is "the activity of clearing up the confusions caused by the bewitchments cast by language. 77

In fact, we should see language and the principles and meaning derived from it as "living forms" rather than logical ones. ${ }^{78}$ Moreover, we should resist the temptation to transform our thoughts and desires into "things." That is, we should resist the idea that every meaningful word must correspond with some object and this very idea must be undercut by means other than argumentation or doctrine. ${ }^{79}$ Rather, it should be undercut by "magnanimity towards idiolects. ${ }^{, 80}$ In the Wittgensteinian framework, a transcendental idea of Reason would not serve as a roadmap to anarchist or anti-

\footnotetext{
76 See chapter 2, "The Wittgensteinian Paradox," in Saul A. Kripke, Wittgenstein on Rules and Private Language (Cambridge: Harvard University Press, 1982).

${ }^{77}$ Ray Monk, How to Read Wittgenstein (New York: W.W. Norton and Company, 2005), 2.

${ }^{78}$ Ibid, 67.

${ }^{79}$ Ibid, 93 .

${ }^{80}$ Richard E. Flathman, Reflections of a Would-Be Anarchist: Ideals and Institutions of Liberalism (Minneapolis: University of Minnesota Press, 1998), 27.
} 
authoritarian theory and action but rather would inform the context-dependent and, more importantly, action-oriented understanding of such theory and action.

Such an incorporation of Wittgensteinian ideas into the postfoundational anarchist project would overcome the "aporia" of Reason in anti-authoritarian thought while still remaining faithful to the postfoundational endeavor. In this case, a context-dependent and action-oriented understanding of Reason and the postanarchist non-rational or antirational program would stand opposed to the universalized authoritative account of the same. In this context, localized "reasons" would be embraced over any ideal of Reason.

Indeed, classical anarchists like Kropotkin also claimed that universalizing schemes (like overarching moral concepts - e.g., thou shall not steal) are illegitimate for similar reasons. Kropotkin thought that these overarching principles served as tools of the ruling classes that protected their power and privilege. Instead, he noted we should act how we should expect others to act in similar situations. Kropotkin thought we should "Do to others as you would have others do to you in the same circumstances." In this way, Kropotkin understood the dynamism of anarchist principles and reasoning. ${ }^{81}$ What Kropotkin advocated in the realm of morality, Wittgenstein explored in the realm of epistemology. It is Wittgenstein's epistemological ideas of "knowing how to go on" an "rule-following" that mirror the context-based approach to action that Kropotkin's variation of the Golden Rule implored in the realm of morality.

\footnotetext{
${ }^{81}$ Peter Kropotkin, 1897, “Anarchist Morality” accessed 10/29/2014. https://www.marxists.org/reference/archive/kropotkin-peter/1897/morality.htm
} 
In order to advance with the postanarchist critique a Wittgensteinian procedural logic is convenient so as to not fall into incoherence. Moreover, in order to avoid falling into universalized renderings of Reason a Wittgensteinian "knowing how to go on" is required to make intelligible a non-contradictory postanarchism. With this incorporation of Wittgenstein, "meaning" would correspond with "doing" and not with any object of our understanding. How we describe or understand a state of affairs or a conceptual rendering of values is embedded in human ways of acting and living. While concepts are inherently ossifying and limiting to the postfoundationalist, actions are both fleeting and liberating to the anarchist and the postfoundationalist. In this framework, concepts are understood as uses of words. "Knowing how to go on" denotes an act rather than simply conceptual comprehension. Since language enables a multiplicity of uses, meanings, and particularities that vary across time, space, and communities, repeated action (i.e., custom) comes to define meaning and guide continued action while acknowledging the ever-changing context in which these actions are embedded. It is this action that will in turn outline the contours of postanarchism's theoretical substance and avoid the trappings of an unwarranted authoritarian Reason in anarchist theory.

In other words, anarchist practices and customs may redeem localized antiauthoritarian reasons for opposing Reason as a transcendental marker or guide without falling into a privileging of Reason. Recognizing and combating the dangers of a privileged Reason in a non-contradictory anti-authoritarian anarchism is only possible when Reason itself is considered as a context-dependent "lived" concept rather than a

\footnotetext{
${ }^{82}$ Richard Rorty, "Universality and Truth" in Rorty and his Critics, ed. Robert B. Brandom (Oxford: Blackwell Publishers, 2000), 25.
} 
universalized noumenal Reason in-itself. The universalizing of meaning and the authoritative rendering of Reason derivative of that universality is challenged by the plurality secured by the Wittgenstinian framework. In this case, no "local" meaning is authoritative over any other rendering or critique of Reason and allows understandings of "lived" concepts as opposed to transcendental ideas.

In thesis 146, in his Philosophical Investigations, Wittgenstein reminds us that only when we can properly understand the rules underlying correct use can we be able to sketch a picture of comprehension that reflects our doing and not merely our indefinite replication of a process. In the same way as one can mimic the brush strokes of a master painter, this alone does not make us a master painter for when our guide runs out we also come to a halt. Underlying our mastery of painting is instead a "state which [sic] is the source of correct use. ${ }^{\prime 83}$ That is correct use, instead of mimicry or perceived adherence to certain ossified conceptual renderings, allows for a non-authoritarian embrace and exercise of Reason.

Moreover, Wittgenstein's idea that to follow a rule is to act in accordance with a communal practice, which is established through continued employment of the rule, informs our "knowing how to go on" and is crucial, I argue, to the postanarchist endeavor and to a consistent anti-authoritarianism. Likewise, "rule-following" in Wittgenstein has no necessary relation with a correct interpretation of meaning or with defined contours of

\footnotetext{
${ }^{83}$ Thesis 146, Philosophical Investigations, trans. by G.E.M. Anscombe, P.M.S. Hacker and Joachim Schulte (Oxford: Wiley-Blackwell, 2009).
} 
philosophical reasoning; rather it is simply oriented towards how we act on the rule. ${ }^{84}$ While explanations for rules eventually run out (as Wittgenstein puts it our "spade" is "turned"), in the end all that matters is what we do. I consider these Wittgensteinian ideas, as action-oriented understandings of meaning where "knowing how to go on" and "rule-following" are considered "performative" abilities and not "rationally articulable" understandings that complement and likely underlie the possibility of a consistent, coherent, and non-contradictory postanarchism and a guide to sketching what a postfoundationalist understanding of anarchism would look like when considering matters of authority in the realm of the intellect. ${ }^{85}$

This is just one possible avenue to overcome Habermasian objections to the postfoundational endeavor. The spirit of anti-authoritarianism in epistemology and ontology generally embraces a healthy skepticism towards many bulwarks of the intellect - most notably the authority of Reason and the essentialisms that usually accompany it as axiomatic truths - while acknowledging that the standards of scientific knowledge are quite arbitrary.

Indeed,

It is clear, then, that the idea of a fixed method, or of a fixed theory of rationality, rests on too naive a view of man and his social surroundings. To those who look at the rich material provided by history, and who are not intent on impoverishing

\footnotetext{
${ }^{84}$ See especially chapters 6 and 15 of Kelly Dean Jolley, ed. Wittgenstein: Key Concepts (Durham, UK: Acumen, 2010).

${ }^{85}$ Nicholas C. Burbules and Paul Smeyers , "Wittgenstein, The Practice of Ethics, and Moral Education", accessed on 9/18/2012, http://faculty.education.illinois.edu/burbules/papers/wittethics.html Also, see theses 151 and 179 in Wittgenstein, Philosophical Investigations.
} 
it in order to please their lower instincts, their craving for intellectual security in the form of clarity, precision, 'objectivity', 'truth', it will become clear that there is only one principle that can be defended under all circumstances and in all stages of human development. It is the principle: anything goes. ${ }^{86}$

Moreover, what should unite consistent anti-authoritarians is not a faith in the autocritical character of Reason or Modernity, or exclusively a rejection of "totalizing" epistemological and metaphysical notions, but rather an acknowledgment of the dangers of "thought" becoming the "source and soul guide of life." In Bakunin's words, consistent anti-authoritarianism requires a recognition that

Life develops out of its own inexhaustible depths by means of a succession of diverse facts, not a succession of abstract reflections; the latter, always produced by life but never producing it, like milestones merely indicate its direction and the different phases of its spontaneous and self-generated development. ${ }^{87}$

Indeed, in the final analysis it seems "allegiance to new ideas will have to be brought about by means other than arguments." $\$ 88$

It is clear that the so-called classical anarchists both celebrated and admonished the excesses of our most cherished faculty. They understood Reason as a vehicle for achieving liberty as well as a potential idol that would stymie our ability to exercise it. The popular characterization of anarchist ontology, epistemology, and their reliance on

\footnotetext{
${ }^{86}$ Feyerabend, 28.

${ }^{87}$ Bakunin, Statism and Anarchy, 135.

${ }^{88}$ Feyerabend, 153.
} 
Reason is caricatured. Moreover, the tools for a consistent anti-authoritarianism that challenges not only authority of the state, the church, and forms of economic domination but also modes of intellectual hierarchy and domination have always been present in these same anarchists despite the insistence of some contemporary scholars. Moreover, contemporary postfoundational efforts to circumvent the forceful Habermasian critique have provided new avenues to challenge the Enlightenment-inspired narrative of classical anarchist thought that some contemporary anarchist scholars have pursued and afforded new ways of thinking about anarchism in the realm of the intellect. 


\section{Chapter 2}

\section{Reason, Anti-Intellectualism, and the Reluctant Modernism}

\section{of William Godwin and Pierre Joseph Proudhon}

The authority of Reason usually exists alongside notions that facilitate its exercise as a faculty and give purpose to its celebration as an ideal. These notions include a stable and univocal concept of the being to which the faculty belongs (i.e., human nature) as well as a faith in the existence of transcendent truth. Absent these notions, the authority of Reason seems to collapse and any consideration of it tends to drift towards a critical deference at best and outright hostility at worst. In other words, without a stable conception of human nature and a transcendent notion of truth underlying any consideration of the authority of Reason that authority is undermined. However, this was not the case with so-called classical anarchist thought.

Generally, anarchists have not found it problematic to celebrate Reason where they thought it appropriate while critiquing notions like human nature, transcendent truth, and similar foundational concepts. While contemporary postfoundational anarchism highlights the poststructural and postmodern onto-epistemological framework (or lack thereof) of a consistent anti-authoritarian anarchism, such a critical attitude towards the ontological and epistemological foundations of anarchist thought was already present in the so-called classical anarchists. ${ }^{89}$ While the so-called classical anarchists are often characterized as firm believers in progress and as staunch individualists who reject the

\footnotetext{
${ }^{89}$ Among the postfoundational anarchists that offer this reading of the classical anarchists and view on consistent anarchic anti-authoritarianism are Saul Newman, Todd May, and Lewis Call. Others like Jesse Cohn and Nathan Jun have questioned the veracity of this reading of the classical anarchists.
} 
state because of their adherence to Enlightenment values, a closer reading reveals that they were quite nuanced in their appreciation of Reason, the scientific method, foundationalisms of all kinds, and the accompanying intellectualism it usually breeds. ${ }^{90}$ By and large, the so-called classical anarchists realized that Reason could be employed for good but it could also represent a danger to the same liberty they sought. ${ }^{91}$

All of the better-known eighteenth and nineteenth century anarchists, including Godwin, Proudhon, Bakunin, and Kropotkin, struggled between notions of immanence and transcendence. They navigated the seemingly transcendent ideals they vociferously defended (e.g. equality, liberty, truth) while celebrating the ephemeral nature of life itself (a life they thought was reflected in anarchy). ${ }^{92}$ While they admitted to the otherworldly ideals that should underwrite anarchist values, these same ideals only existed as part of our everyday life. They were only manifested in living. It was this tension between what could simply be termed theory and individual practice that itself served as the prime philosophical impetus of anarchist thought. ${ }^{93}$ Such a struggle continues to this day in

\footnotetext{
${ }^{90}$ For a thorough intellectual history of anarchism see George Woodcock, Anarchism: A History of Libertarian Ideas and Movements (Cleveland, Meridian Books, 1962).

${ }^{91}$ Anarchism is perhaps the most intellectually varied and, by its nature, pluralistic mode of political theorizing. From the utilitarian and deterministic Anarchism of William Godwin to the Socialist Anarchism of Mikhail Bakunin to the nihilistic and anti-metaphysical Anarchism of Max Stirner labeling certain thinkers as foundational or "classical" is difficult. However, it's usually acknowledged that the "classical anarchist" thinkers included William Godwin, Pierre-Joseph Proudhon, Mikhail Bakunin, and Peter Kropotkin.

${ }^{92}$ Nathan Jun, Anarchism and Political Modernity (New York: Continuum, 2012), 126-7.

${ }^{93}$ Woodcock describes the "secular exaltation" of the individual and the personalistic view of religion that accompanied the later stages of the Reformation as similar to the anarchist conception of "immanent justice." The idea stressed the individual and personal measure of justice as opposed to transcendental forms. See Woodcock, Anarchism, 40.
} 
postfoundational anarchist literature. ${ }^{94}$ However, novel ways of tackling these issues in contemporary anarchist thought have largely reflected the debates among $19^{\text {th }}$ century anarchist thinkers and their interlocutors.

More specifically, two such anarchist thinkers, Godwin and Proudhon, exhibited general deference to the authority of Reason and yet did not subscribe to purely transcendental ideas about auxiliary notions like human nature and transcendent truth. While they both privileged Reason they acknowledged its limitations and dangers. In doing so, they illuminated the interrelation of human nature, transcendent truth, and Reason. They both couched their calculated embrace of Reason and its supporting concepts in a thorough grappling with the defining features of modernity. While they both believed in the emancipatory potential of the Enlightenment, they also challenged the framework that grounded this enterprise. Moreover, they illuminated ways in which the Enlightenment itself undermined static understandings of human nature as well as an unthinking deference to Reason and intellectualism. Unlike their classical anarchist counterparts, Bakunin and Kropotkin, they both gradually shifted towards a more critical and hesitant embrace of Reason and authoritative accounts of auxiliary notions of human nature and science. ${ }^{95}$

\footnotetext{
${ }^{94}$ See especially, Todd May, The Political Philosophy of Poststructuralist Anarchism (University Park, PA: Pennsylvania State University Press, 1994); Lewis Call, Postmodern Anarchism (Lanham, Md.: Lexington Books, 2002); Saul Newman, The Politics of Post Anarchism. (Edinburgh: University of Edinburgh Press, 2010).

${ }^{95}$ As I will argue in the third chapter, Mikhail Bakunin and Peter Kropotkin had a consistently critical attitude towards Reason and the predictable intellectualism that would follow from its celebration.
} 


\section{William Godwin as Repentant Intellectualist}

Beginning in the early 1700's, the politically radical intelligentsia of England and Europe, of which William Godwin ${ }^{96}$ was a primary figure, were consumed by the ideational force of private judgment and Reason as a propeller of progress. ${ }^{97}$ What most concerned and inspired Godwin, as well as other classical anarchists and radical thinkers, was a faith in deduction, empiricism, the scientific method, and similar exercises of individual private judgment seemingly independent of the social forces that may have constrained and conditioned them. According to Godwin and others, it was this independence from hierarchical social forces (e.g., the church, the state) and the arbitrary authority they exercised that made progress possible.

If given a chance to flourish, Reason would propel human progress and hold to account these arbitrary exercises of authority. Indeed, as Francis Bacon put it in his 1620 book Novum Organum, the "formation of ideas and axioms by true induction is no doubt the proper remedy to be applied for the keeping off and clearing away of idols." 98 A

\footnotetext{
${ }^{96}$ Though different editions of Godwin's most famous work, Enquiry Concerning Political Justice and its Influence on Modern Morals and Happiness, are often quoted and Godwin seems to have shifted his position on several issues in subsequent editions, I will be focusing extensively on William Godwin, Enquiry Concerning Political Justice and its Influence on Modern Morals and Happiness (Harmondsworth, Middlesex, England: Penguin Books, 1976 [1798]) which is the third and final edition. I focus on this edition because it is the final philosophical expression of Godwin's views.

${ }^{97}$ See Israel, Radical Enlightenment.

${ }^{98}$ Issac Kramnick, ed., The Portable Enlightenment Reader, (New York: Penguin Books, 1995), 41. Here, Bacon is referring to our ability to overcome the idols of the tribe, the cave, the market, and the theater. By these Idols he meant the false idea that "man is the measure of all things" (Idols of the Tribe), our own ideological and personal distortions of reality (Idols of the Cave), the everyday relations among human beings that impose a vulgar understanding of reality through inappropriate and false descriptions through discourse (Idols of the Marketplace), and the dogmas of philosophies and other systems of thought (Idols of the Theater).
} 
century later Enlightenment figures would continue to champion the ideal of "true induction" to overcome superstition, parochialism, and the power and authority that were often empowered by and dependent on them. From the "perfectionism" of man in the thought of Joseph Priestly and Marquis de Condorcet to notions of historical and sociological progress in Giambattista Vico and Adam Smith, the idea that history (which reflects this progress) is a "change from darkness to light, from superstition to sound knowledge and from a most debasing servitude to a state of the most exalted freedom" is central to many of Godwin's contemporaries who were themselves inspired by Bacon's prescription. $^{99}$

As Godwin put it, our "modes of social existence, are susceptible of perpetual improvement" and "It is to the improvement of reason therefore that we are to look for the improvement of our social condition." ${ }^{\prime 100}$ According to the anarchists everyone possesses this faculty of reason and it is through its exercise that the ideal of Reason would trump existing hierarchical social forces. It is important to note that it was precisely reason's egalitarian nature (i.e., the fact that anyone could exercise the faculty of reason) that gave it revolutionary potential. If only we were all able to access and be inspired by Reason we would recognize injustices and be empowered to correct them. While the ability to access the faculty of reason was sometimes hampered by social conditions, we had an innate ability to access it given the right environment. Moreover, it

\footnotetext{
${ }^{99}$ This part of the concluding chapter to Joseph Priestley's Letters to the Honorable Edmund Burke are included in Kramnick, The Enlightenment Reader, 382-382. Excerpts of Condorcet's introduction to his Sketch for a Historical Picture of the Human Mind (pp. 387-395), Vico's introduction to Principles of a New Science Concerning the Common Nature of the Nations (pp. 351-356), and excerpts of Smith's Lectures on Jurisprudence are all included in Kramnick, The Enlightenment Reader.

${ }^{100}$ Godwin, Political Justice, 77.
} 
was Reason itself that would usher in the conditions for its own flourishing. Indeed, the seed to social progress was in Reason's eventual triumph over the forces of hierarchy, arbitrary authority, and inequality.

According to Godwin's Political Justice, our very equality lay in the underlying faculty of reason and its attunement to truth. Every person could recognize the authority of Reason given the right social conditions. Such recognition, however, was a solitary affair. In many cases, social and political relations interfered with an attunement to Reason. Propaganda, the Church, and social customs all made it increasingly difficult to attune ourselves to Reason and ultimately truth. While the reasons for our occasional inability to recognize Reason and truth lay in our intercourse with others, we escaped this challenge by relying on our own unimpeded private judgment. Nevertheless, the existence of an independent marker, existing outside the everyday lives of all who share the faculty of reason, is a necessary and guiding end of our own individual efforts.

He notes, "There is no satisfactory criterion marking out any man, or set of men, to preside over the rest... all men are partakers of the common faculty, reason; and may be supposed to have some communication with the common instructor, truth." ${ }^{101}$ It is the access to truth via the faculty of reason that made us equal. Such equality begat, according to Godwin, a rejection of all authority other than Reason itself. Even the authority of law was meaningless unless it agreed with our private judgment. It was

${ }^{101}$ Ibid, 231. 
necessary that "every man should stand by himself, and rest upon his own understanding.",102

According to Godwin, the only laws of any significance and worthy of deference or respect are the laws of Reason. This importance stemmed from the fact that they were prior to the man-made laws that often stymied the flourishing of Reason. ${ }^{103}$ Indeed, the coercive nature of prescriptive law itself damaged the march towards "perfectibility" for Godwin. " 'All coercion', as Godwin affirms, 'sours the mind'. In time, the 'simple' exercise of omnipotent reason will replace the tyranny of positive laws. In the meantime, whilst also enduring its coercive penalties, humanity must dedicate itself to the ultimate destruction of this tyranny.",104

\section{As Collings notes, Godwin}

Attacked any attempt to reduce reason to a legal code, arguing that no code could ever anticipate the contingencies of any specific case, that rather than resolving legal disputes it would only give rise to the need for more codification ad infinitum. The only possible standard of justice was uncodified [sic] justice itself, whose dictates must be determined case by case in light of reason alone. ${ }^{105}$

\footnotetext{
${ }^{102}$ Ibid, 198
}

${ }^{103}$ David Collings, "The Romance of the Impossible: William Godwin in the Empty Place of Reason" English Literary History, 70:3 (2003): 847-874.

${ }^{104}$ Ian Ward, "A Love of Justice: the legal and political thought of William Godwin," The Journal of Legal History, 25:1 (2004): 10.

${ }^{105}$ Collings, "Romance of the Impossible," 847. 
That is, according to Godwin's reasoning, the only ideal standard of justice worthy of the name are the dictates of Reason that are always capable of adapting to specific circumstances. The flexibility and contingent character of these dictates preserve the need to adapt to specific circumstances while still reflecting some otherworldly or eternal standard that Godwin does not make clear.

Moreover, Reason, in Godwin, frames and underlies social relations. It is the basis for any conception of natural law. He notes,

Legislation, as it has been usually understood, is not an affair of human competence. Immutable reason is the true legislator, and her decrees it behooves us to investigate. The functions of society extend, not to the making but the interpreting of law; it cannot decree, it can only declare that which the nature of things has already decreed, and the propriety of which irresistibly flows from the circumstances of the case. ${ }^{106}$

In other words, the "nature of things" is already in line with Reason; we just have to be able to recognize it. This may seem paradoxical to any understanding of anarchist thought given its traditional emphasis on revolution and social change. However, there is a strong determinist streak in Godwin's thought and Godwin considers this already determined social reality as undeniably anarchistic in nature. Recognition of such a reality is contingent on Reason's ability to decipher it, and that ability is itself paradoxically dependent on the kind of social change (ridding society of authoritarian

\footnotetext{
${ }^{106}$ Godwin, Political Justice, 236.
} 
structures) that would enable Reason to flourish. It is in this way that the immutable laws of Reason both inform and recognize the ideal social organization.

According to Godwin, human beings, having equal access to the laws of Reason, should therefore rely on their private judgment to evaluate both personal and political disagreements or questions. It is especially pertinent that an attunement to Reason underlies all justification of political relationships (if any). Godwin believed that in appealing to Reason any raison d'état necessarily fades into oblivion. That is to say, the special logic of state that informs matters of governance and that justifies everything from the quelling of a domestic rebellion to war with other countries is rendered both incoherent and utterly meaningless when faced with the dictates of Reason. The logic that operates in the sphere of politics or statesmanship is always voided by "immutable reason." Indeed, no social organization or political authority reflected the immutable laws of Reason better than our own private judgment. Godwin notes, "The conduct of an enlightened and virtuous man can only be conformable to the regulations of government so far as those regulations are accidentally coincident with his private judgment..."107 Moreover, he emphasized that, "The true supporters of government are the weak and uninformed, and not the wise. In proportion as weakness and ignorance shall diminish, the basis of government will also decay."108 In other words, the more we are empowered to exercise Reason the more we will recognize the needlessness of government. The enabling of individuals to rely on their private judgment and access Reason's immutable truths is dependent on the abolition of the authoritarian structures (the Church and the

\footnotetext{
${ }^{107}$ Ibid, 247.

${ }^{108}$ Ibid, 247-8.
} 
State) and this same abolition requires access to Reason. The argument seems circular but is not contradictory to Godwin's own determinist beliefs.

According to Godwin, Reason regulated everything from the lust for power and wealth, liberty and equality, to moral as well as intellectual progress. ${ }^{109}$ Private judgment, guided by Reason, stood as both the intellectual bulwark of informed opinion (i.e. a rejection of traditional sources of knowledge, especially the church) and the source of inspiration for the radical upheaval of traditional social and political hierarchies. Indeed, Godwin saw the workings of Reason as responsible for the civilizing effects of limited government and other social and political liberties.

In addition to Reason and a transcendent notion of truth, another main idea at work in Godwin's Political Justice is a utilitarianism also grounded in faith in Reason. While making reference to abstract or immutable truth he often couched it in the language of utility. He often understood truth as inevitably and undeniably consistent with the greatest good for the greatest number. The truths of right and wrong as with every guide to action are recognized by a thorough consideration of their utility. Godwin assumes such utility reflects these truths. However, the "calculation of consequences" does not necessarily constitute "right and wrong" but our "private judgment" and "public deliberation" are a means to discover these in Godwin. According to F.E.L. Priestly,

\footnotetext{
${ }^{109}$ For example, Godwin notes, "When the laws of morality shall be clearly understood, their excellence universally apprehended, and themselves seen to be coincident with each man's private advantage, the idea of property in this sense will remain, but no man will have the least desire, for purposes of ostentation or luxury, to possess more than his neighbor" (Godwin, Political Justice, 199). See also Godwin as a conservative on the gradual progress of the intellect and other matters on pp. 251-2 in Political Justice. Also, Godwin returns repeatedly to the idea that progress is self-regulating through Reason. He notes that "everything may be trusted to the tranquil and wholesome progress of knowledge, and that the office of the enlightened friend of political justice, for the most part, consists in this only, a vigilant and perpetual endeavor to assist the progress" (Godwin, Political Justice, 335).
} 
Godwin already supposes that our considered judgment of utility will reveal immutable truths. ${ }^{110}$ For Godwin,

The unchanging truths of the universe, if known, must dictate actions which will produce the greatest good, but since human judgments are fallible, no judgment or multiplicity of judgments as to the utility of an action will necessarily reveal its relation to universal truth; still less will multiplicity or even universality of judgment constitute universal truth. Utility may be permitted to be the criterion of virtue, as for all practical purposes it must be; but it is not its essence. ${ }^{11}$

Nevertheless, we should be careful not to attribute a wholly independent and external existence of Reason to Godwin (though at times he clearly seems to imply it). Godwin claims that our powers of abstraction that accompany and in fact necessitate the faculty of reason are inseparable from mind itself, that is our inner and abstract conception of our thinking faculty and ourselves. ${ }^{112}$ Curiously, it is only the human mind that can conceive Reason (an abstract yet apparently truly existing notion) and it can only do so because it, partly, brings it into existence. Despite this seemingly idealist or subjectivist point of view, Godwin recognized that we all have equal access to an idealized Reason and should endeavor to attune ourselves to it for the sake of progress. In attuning ourselves to Reason and assuming that its laws are equally accessible, Godwin presupposes both the existence of an external marker of Reason and that we are all endowed with an equal

\footnotetext{
${ }^{110}$ F.E.L. Priestly, "Platonism in William Godwin's Political Justice," Modern Language Quarterly, 1943, 4: 1 (2007): 63.

${ }^{111}$ Priestly, "Platonism in William Godwin's Political Justice," 64.

${ }^{112}$ Godwin, Political Justice, 158.
} 
capacity to exercise this ideal (as a faculty) in us. He claims this all the while occasionally referring metaphorically to Reason as a personified legislator whose decrees we should follow. ${ }^{113}$ While the metaphysical status of Reason is sometimes unclear in Godwin the basic thrust of its role in social justice is clear.

Reminiscent of an intellectual "invisible hand," the belief that Reason propels progress on social, economic, political, and intellectual fronts reflects Godwin's insistence that unimpeded private judgment is the key to any semblance of justice. No institution could hope to mediate between people and reason, or between people themselves. ${ }^{114}$ Godwin, like most anarchists, understood human relations to exist outside any political understanding of social organization. In other words, he understood human relations as independent of any political framework. Human relations are both best understood as existing outside political relations and usually do exist outside or independent a political framework. Godwin and anarchists generally recognize that our everyday lives mostly revolve around personal, inter-personal, social, economic and cultural concerns. While these may have a relationship with political organization the everyday experience of these spheres of life exist independent of politics, government, and the logic of state.

Included in these human relations are understandings of justice. For Godwin especially, it is a justice rooted in the primacy of private judgment. Usually taken to be a political idea par excellence, justice is understood among the classical anarchists to lie in

\footnotetext{
${ }^{113}$ Ibid, 236.

${ }^{114}$ Collings, "Romance of the Impossible," 847.
} 
the realm of interpersonal relations not mediated by the state. Godwin proposed that we examine justice "as it exists among individuals" and avoid in its search a "political view." ${ }^{115}$ In this way, government is largely considered superfluous. When most of our waking lives involve no thought of "political" justice it makes little sense to understand justice as exclusively (or even primarily) a governmental matter. ${ }^{116}$

In Godwin, our concern for justice should be mediated by Reason itself (independent of institutions that claim to channel it). There is no idea of justice independent of the dictates of Reason. According to Godwin, Reason is both the ideal we should aspire to and the means to reach that ideal. The thrust of Godwin's argument, and of the classical anarchists that followed, advocated thinking of justice as necessitating both an appeal to Reason and an exercise of the same. Reason was the ultimate end and perpetual means by which justice is both conceived and employed. Godwin and the classical anarchists embraced a faith in Reason as both leading to truth and accordingly realizing justice.

Curiously, Godwin also relied heavily on a deterministic view of nature to justify action. Far from considering determinism as discouraging action (since it would seem pointless given the inevitability of results) Godwin thinks it imperative to desire the very end he considers inevitable. According to Godwin, determinism actually encourages our search for truth and reinforces the idea that Reason reflects reality, constitutes it, and is only through it that we are able to discover the same.

\footnotetext{
${ }^{115}$ Godwin, Political Justice, 169.

116 By "political" justice I mean the usual understanding of legal remedy or some other redress obtained through a parliamentary or otherwise governmental process.
} 
Indeed, Godwin notes,

The more I resign myself to the influence of truth, the clearer will be my perception of it. The less I am interrupted by questions of liberty and caprice, of attention and indolence, the more uniform will be my constancy. Nothing would be more unreasonable than that the sentiment of necessity should produce in me a spirit of neutrality and indifference. The more certain is the conjunction between antecedents and consequents, the more cheerfulness should I feel in yielding to painful and laborious employments. ${ }^{117}$

This deterministic view allows for a "tendency to make us survey all events with a tranquil and placid temper, and approve and disapprove without impeachment to our selfpossession." 118

However, there seems to be some circular logic at work here. This determinism seems to rely on an established Reason that both constitutes reality as well as helps us understand it. According to Godwin we are naturally attuned to truth. However, as Weston explains, "this automatic perception of truth and the moral action it engenders is conditional upon our attaining that 'perfectly voluntary state' of consciousness which evidences 'the perfection of the human character." 119 Such a "perfectly voluntary state"

\footnotetext{
${ }^{117}$ Ibid, 356.

${ }^{118}$ Ibid, 358.

${ }^{119}$ Rowland Weston, "Politics, Passion and the 'Puritan Temper': Godwin's Critique of Enlightened Modernity," Studies in Romanticism, 41: 3 (Fall 2002): 447.
} 
is dependent on overcoming the social and political obstacles to a flourishing of Reason. But, such flourishing is only possible when we achieve this state.

Nevertheless, Godwin's view of Reason in Political Justice was not entirely grounded strictly on this view. Sometimes, he seemed to anticipate romanticist thought in giving primacy to our sentiments. Godwin notes, "Reason is not an independent principle, and has no tendency to excite us to action; in a practical view, it is merely a comparison and balancing of different feelings." ${ }^{120}$ The reader can also infer from Godwin the dangers of basing social and political life on an ideal of Reason that claims to access immutable truths. He claims that ossifying certain social practices via institutions (privileging, say, private judgment concerning market transactions or a "rational" education based on "critical thinking" at universities) is dangerous. He notes, "institutions calculated to give perpetuity to any particular mode of thinking, or condition of existence, are pernicious." ${ }^{121}$ Godwin is of course making reference to the damaging role of theological dogmatism or the often unquestioned justificatory frameworks of state authority, but we can imagine how a hardened faith in Reason and our supposed abilities to access the truths it reveals (e.g., about the workings of the market, our human nature, knowledge of "things as they are"122 ) could be just as "pernicious."

In any case, the thrust of Godwin's philosophy in Political Justice is recognition of the innumerable obstacles to the proper exercise of reason (and subsequent recognition

\footnotetext{
${ }^{120}$ Ibid, 77.

${ }^{121}$ Ibid, 77-8.

${ }^{122}$ Godwin's novel Caleb Williams, or Things as They Are explores issues concerning appearance vs. reality (e.g., a late $18^{\text {th }}$ century English aristocratic culture that obscures the injustices born of it).
} 
of utility). Such a proper exercise would give us access to its "instructor," truth. While we often rely on custom and habit rather the faculty of reason, Godwin would urge the kind of social environment conducive to creating customs and habits already attuned to Reason.

Interestingly, Godwin forcefully shifts to a more complex view of Reason in his literary works. Godwin exchanges "universalism" and "essentialism" in Political Justice for a "skeptical romanticism" that highlights the contingency in our natures. ${ }^{123}$ That is he shifts to a more holistic understanding of human beings and what it means to be human. Godwin realizes the ratiocination so critical to the detached objectivity of Political Justice is actually incapable of generating the attunement to Reason necessary to justice. ${ }^{124}$

The tension between an immutable reason and humility (and the necessity of gaining insight with the help of others) permeates Godwin's novels. As Collings explains, while the "aggression implicit in absolute reason dominates in the relatively unselfconscious" Political Justice, his novels "expose the cost of such conceptual violence in acute, implicitly self-critical, and progressively more sweeping terms. Total conceptual revolution modulates into a searching critique of the irrational component of rational absolutism." 125

\footnotetext{
${ }^{123}$ Weston, "Politics, Passion and the "Puritan Temper'," 446.

${ }^{124}$ Weston, "Radical Enlightenment and Anti-Modernism," 18.

${ }^{125}$ Collings, "The Romance of the Impossible," 848.
} 
Probably his most popular novel, Things as They Are, or The Adventures of Caleb Williams best embodied Godwin's changing attitudes. While still thoroughly steeped in a rationalistic ethos it also opens a space for critical reappraisal of our most cherished faculty. ${ }^{126}$ The story centers on Caleb Williams and his employer Ferdinando Falkland who has committed a murder and is noticeably unnerved by his act. While Falkland felt compelled to commit the crime (the victim of his crime, Barnabas Tyrrel, was a cruel man and apparently deserving of such punishment) he is nevertheless racked with guilt. Williams insists on finding out the truth and once he does is subject to Falkland's ire. The story concludes with Falkland being emotionally moved to confess the murder by the example of Williams' integrity.

In Caleb Williams the miscarriages of justice (in this case the failure to initially convict Falkland of murder) are considered in concert with the injustices of the world (which arguably caused Falkland to commit the crime). This interplay and vagueness in assigning moral blame for events make up the heart of "things as they are." While the novel obviously highlights the horrors of the justice system and the hypocritical mores of England's aristocratic class it also makes a philosophical statement about the indeterminable reality that permits them. It is this indeterminacy that points to the gulf between our ability to decipher reality and our pretension in assuming we can control it. In considering the injustice of Falkland's actions and his persecution of Caleb, Godwin

\footnotetext{
${ }^{126}$ William Godwin, Caleb Williams (Peterborough, Ontario, Canada: Broadview Literary Texts, 2000).
} 
navigates our inability to fix certain wrongs even if we can rationally contemplate how to bring about justice. ${ }^{127}$

More directly than does Caleb Williams, Godwin's novel St. Leon critiques our modern faith in Enlightenment values. St. Leon introduces the reader to the hubris inseparable from claims to unlimited resources and eternal youth and vigor. Godwin shows how even what can seemingly make us free ensnares us in other modes of subjection. The gradual fall of the protagonist, Reginald de St. Leon, reflects our intractable yearning for control over nature and society. The protagonist, endowed with "exhaustless wealth and eternal youth"128 seeks to better the circumstance of his family and countrymen. However, such efforts only invite suspicion and produce calamity. Despite his grandiose schemes to improve the human condition and help his fellows (e.g., attempting to revitalize the economy of a Hungarian village and giving charity to the poor), all his efforts end in catastrophe. He is alienated from his family and persecuted by governmental authorities thanks to suspicions of witchcraft and other intrigues. His actions, though well intentioned, force him into exile and bring dishonor to his family. Despite his "divine abilities" Reginald becomes increasingly isolated. ${ }^{129}$ His fumbling attempts to help his family and neighbors are handicapped by his embrace of the philosopher's stone and the elixir of life that proves the fault in our Enlightenment-

\footnotetext{
${ }^{127}$ Collings, on page 857 of "The Romance of the Impossible," referring to Caleb Williams, explains, "...by admitting to the vast gap between intention and meaning he implicitly accepts the possibility that the effects of action are never knowable in advance, that one cannot finally tell the difference between imaginary and real utility, and thus that no action can be entirely free from self-deception."

${ }^{128}$ William Godwin, St. Leon: A Tale of the Sixteenth Century (New York: Arno Press, 1972), 2.

${ }^{129}$ Godwin, St. Leon, iii.
} 
inspired attempts to command and control. St. Leon radically "undercuts the fantasy of inhuman knowledge - the secret of the philosophers stone - even as it enables readers to share the experience of possessing such knowledge."130

According to Rowland Weston, St. Leon represents Godwin's “rejection of the sufficiency of modern, scientific rationalism as a guide to, and guarantee of, the radically renewed social and political order he and other progressives of the late eighteenth century pursued." ${ }^{\prime 131}$ Indeed, Reginald quickly realizes that although he has access to unlimited wealth and eternal youth, he is unable to communicate this knowledge to anyone. This robs the possession of such insight of any value or meaning. Moreover, this very knowledge serves as an obstacle to his relations with his family (a prominent theme throughout) and conveys Godwin's increasing stress on "domestic affections" all the while highlighting the futility of grand schemes of social engineering. In this way, he highlights classic anarchist themes while also emphasizing the role our sentiments play in both personal and public success.

Perhaps even more than St. Leon, Godwin's novel Fleetwood communicates the centrality of affections and emotions to our development and "private judgment." 132 Despite his early celebration of Reason in Political Justice, Godwin is considered to have shown increasing appreciation for the impact of feelings and our relationships with others

\footnotetext{
${ }^{130}$ Collings, "The Romance of the Impossible," 849.

${ }^{131}$ Rowland Weston, "Radical Enlightenment and Anti-Modernism: The Apostasy of William Godwin (1756-1836)" in The Journal for the Study of Radicalism, 7:2 (Fall 2013): 1.

132 William Godwin, Fleetwood: Or, The New Man of Feeling (Broadview Literary Texts: Peterborough, Ontario, Canada, 2001), 9.
} 
on our "determined" life choices. In Fleetwood Godwin does so by tackling several

Rousseauian themes.

In this coming-of-age story, Casimir Fleetwood's upbringing and tutelage leave him ill-suited for the real world (specifically for relationships with others). His interpersonal relations leave much to be desired (they usually end in tragedy) and reflect his descent into lunacy as a consequence of his unsociable and lonely upbringing. While he eventually recovers some of what he has lost (his marriage, his child, the respect and love of others) he is led to reflect on the dangers of solitary life (which tends towards delusion and disappointment).

In many of his works, Godwin largely responded to Rousseau's arguments concerning education and its role in fostering communal sensibilities. Godwin is responding mostly to Rousseau's insistence that isolation from the harmful effects of others is a positive influence on a child's rearing and education. While Rousseau would claim learning with others would corrupt our natural abilities, Godwin would insist that learning in isolation would lead to the same. ${ }^{133}$ Fleetwood continued this response in literary form (sometimes quite explicitly). ${ }^{134}$ As the plot develops, it becomes obvious

\footnotetext{
${ }^{133}$ See for example selections from The Enquirer, Reflections on Education, Manners and Literature in Godwin, Fleetwood, 429-36.

${ }^{134}$ In the introduction (p. 25) to this edition of Fleetwood, Gary Handwerk and A.A. Merkley explain the connection well. They note, "In true Rousseavian fashion, Fleetwood is educated by nature, left free by his melancholic father largely to wander as he will and to develop his sensibility amid the wild Welsh landscape. As an adult, Fleetwood is deeply attracted by the life and ideas of Rousseau; his immediate impetus for getting to know the Macneil family, for instance, stems from the latter's reputedly close friendship with Rousseau. Macneil's brief portrait of Rousseau (p. 244) describes him as a man of 'exquisite sensibility,' a victim to the unfeeling and calculating nature of the social arrangements among which he was forced to live. Despite spending much of his life among 'the French egoists,' Rousseau's life showed how the mind could use its sensibility for nature and for everyday life to rise above the petty rivalries of social existence."
} 
how Casimir's education becomes an impediment to his ability to confront the vicissitudes of life. Egoism and a sense of grandiosity born of his "natural education" removed from the corruption of society lead to his intractable contempt for humanity (and his inability to relate to others and fully share in the delights of companionship and fellow feeling). The lesson here concerns what goes wrong when we reject the contingencies of life with others and instead misguidedly celebrate an idealized solitary reflection that ostensibly favors the unimpeded exercise of reason.

Indeed, Godwin's literary works show the futility of the pronounced ratiocination of Political Justice. Though Godwin makes sure to indicate the direction of "progressive modernity" to the reader (e.g., ideas of perfectibility, indefinite improvement, a celebration of Reason), he also makes sure to refuse it. ${ }^{135}$ Godwin interrogated one of the defining debates of the Enlightenment: the reconciliation between "sense and sensibility, reason and romance." ${ }^{, 136}$ Godwin concluded that society could not be understood simply in terms of natural law or the dictates of Reason. He embraced the idea that a progressive and tolerant society could only be an expression of fellow feeling and it could not be manifest in institutions of government. ${ }^{137}$

Godwin's faith in Reason's liberating yet deterministic role in Political Justice offers a simplistic understanding of classical anarchist sentiments. It is a point of view that would evolve in Godwin. He would eventually convey an appreciation for the limits

\footnotetext{
${ }^{135}$ Collings, "The Romance of the Impossible," 849.

${ }^{136}$ Ian Ward, "A Man of Feelings: William Godwin's Romantic Embrace" in Law and Literature, 17: 1 (2005), 23.

${ }^{137}$ Ibid.
} 
of Reason in his literary works that also reflect the general thrust of classical anarchist thought. Other classical anarchist thinkers shared Godwin's devotion to our most esteemed faculty but likewise did not translate such faith into axiomatic understandings of human nature, the nature of political society, or intellectual life more generally.

\section{The Hesitant Rationalism of Pierre-Joseph Proudhon}

Proudhon is sometimes described as a child of the Enlightenment who shares the excitement of the philosophes over the seemingly boundless increase in human knowledge and our ability to transmit such knowledge through education. He shares with others in both the anarchist and Enlightenment traditions a belief in our individual abilities to decipher reality and collectively foster meaningful progress and juxtaposes such belief to religious faith and divine guidance or any other external authority. ${ }^{138}$

While Proudhon certainly shared with his Enlightenment kin a thorough celebration of Reason and auxiliary notions such as a clear conception of human nature (in Proudhon's case an asocial and egoistic character that could be overcome by creating the right social conditions), as his thought evolved he came increasingly to oppose an unadulterated reverence of Reason and a faith in the accompanying scientific methodology that Enlightenment thinkers often praised. Despite the evolution in Proudhon's attitude towards our most esteemed faculty and the supporting scientific and anthropological worldviews that sustain it, he was remarkably consistent in his views on political economy as the starting point of all inquiry. It is this consistency that structured

\footnotetext{
${ }^{138}$ Robert L. Hoffman, Revolutionary Justice: The Social and Political Theory of P.J. Proudhon (Urbana: University of Illinois Press, 1972), 7.
} 
his theory of justice and, like his radical comrade, Marx, sought to understand reality in terms of economics so as to revolutionize the same. In other words, despite his evolving views on the importance of Reason he retained an axiomatic understanding of political economy that reflected the kind of intellectualism of which many anarchists are wary.

Interestingly, despite this common point of departure and their revolutionary ideals, Proudhon and Marx disagreed substantially over the notion of authority within the revolutionary process. ${ }^{139}$ This disagreement neatly highlights Proudhon's sometimes skeptical attitude towards Reason. In a letter to Marx, Proudhon was clear he did not want to substitute capitalist oppression and exploitation with the tyranny of a "new intolerance." In this case, he was referring to the intolerance of the "religion of reason." Despite Proudhon's desire to overcome all a priori dogmatisms and perpetually question our philosophical assumptions with "eloquence and irony" he also held fast to a foundational place for political economy within his philosophy. ${ }^{140}$

In fact, as Proudhon jostled with Marx on issues of authority and vanguardism he was also engaging in productive dialogue over the authority of Reason. Marx is well known for his claims that knowledge should be rooted in the material conditions of

\footnotetext{
${ }^{139}$ While Marx directly and infamously responded to Proudhon's Philosophie de la misère with his Misère de la philosophie this had little to do with disagreements over the notion of authority in the revolution. Here he disagreed with some aspects of Proudhonian political economy. While it was clear that Marx did not like Proudhon (as is evident in the forward to Marx's infamous response) it is Proudhon is who makes clear his disagreement with Marx over issues of authority in the revolution (especially in his correspondence). See Proudhon's general attitude to authority in much of his correspondence at "Letters from: Proudhon, P-J. (1875) Correspondance de P.-J. Proudhon; Tome Troisiéme Librairie Internationale; Paris.," Anarchy Archives, accessed August $14^{\text {th }}, 2015$. http://dwardmac.pitzer.edu/Anarchist_Archives/proudhon/letters/letters.html.

${ }^{140}$ For Proudhon's reaction to Marx's apparent authoritarianism see Proudhon's letter to Marx dated 17 May, 1846 available at Anarchy Archives, accessed August $14^{\text {th }}, 2015$, http://dwardmac.pitzer.edu/Anarchist_Archives/proudhon/letters/proudhontomarx.html.
} 
"concrete existence" and Proudhon echoed Marx in his repudiation of absolutism, both ecclesiastical and intellectual. Proudhon was intent on highlighting that there is no final destination but rather "indefinite progress and metamorphosis" by which we are characterized as a species and as a society. ${ }^{141}$ Nevertheless his axiomatic understanding of political economy agreed with Marx's view of the importance of material conditions and also reflected his belief in objective truth.

This rootedness in the material conditions of concrete existence is crucial for Proudhon. This existence is manifested in the truths of political economy. The objectivity of political economy served as a linchpin for solidarity with the oppressed and exploited people of the world as well as the guiding truth and metaphysical grounding of Proudhon's theory of justice. Proudhon was clear in the objective character of political economy. He notes that

It is indeed with political economy as with other sciences: it is inevitably the same throughout the world: it does not depend upon the fancies of men or nations: it yields to the caprice of none. There is not a Russian, English, Austrian, Tartar, or Hindoo [sic] political economy, any more than there is a Hungarian, German or

\footnotetext{
${ }^{141}$ See Proudhon's De la Justice dans la revolution et dans l'Eglise and Hoffman's treatment of these themes in Revolutionary Justice, p. 116-7. See also Shawn P. Wilbur's partial translation of Proudhon's Justice in the Revolution and in the Church, volume one, available at "Pierre-Joseph Proudhon, Justice in the Revolution and in the Church, Vol. 1 (in progress)," Working Translations: Writings by Anarchists, Socialists, Feminists and Dreamers, translated from the French, accessed August $14^{\text {th }}, 2015$, http://workingtranslations.blogspot.com/p/pierre-joseph-proudhon-justice-in.html.
} 
American physics or geometry. Truth alone is equal everywhere: science is the unity of mankind. $^{142}$

It is this truth that should guide the efforts of humankind in improving their lot. The "science" of political economy (considered by Proudhon the ultimate and grounding science underlying the study of all other subject matter) was seen as voiding the necessity of government and being the "sovereign arbiter of interests." 143

Indeed, Proudhon shared a thoroughly materialist metaphysical outlook with Marx. Proudhon notes, "In other words, economic science is to me the objective form and realization of metaphysics; it is metaphysics in action, metaphysics projected on the vanishing plane of time; and whoever studies the laws of labor and exchange is truly and specially a metaphysician." ${ }^{144}$ And, in a further allusion to the grounding philosophical framework of political economy, he equates what he considers the main driver of political economy (i.e. labor) with the universality of God's creation. Proudhon notes, "The labor of man continues the work of God, who, in creating all beings, did but externally realize the eternal laws of reason."

Nevertheless, there is a curious tension between the objectivity of political economy and the arbitrariness of property in Proudhon. While political economy reflects

\footnotetext{
${ }^{142}$ P.J. Proudhon, General Idea of the Revolution in the Nineteenth Century (New York: Gordon Press, 1972 [1851]), 283.

${ }^{143}$ Ibid.

${ }^{144}$ Pierre Joseph Proudhon, System of Economic Contradictions or, The Philosophy of Misery (New York: Arno Press, 1972 [1888]), 43.

${ }^{145}$ Ibid, 44.
} 
underlying metaphysical truths, property, a seemingly integral feature of political economy, is contingent on power, chance, and a host of other factors completely opposed to metaphysical truth. Property, after all, is theft! ${ }^{146}$

Interestingly, Proudhon is able to simultaneously praise the objectivity of political economy, celebrate Reason as the guide to deciphering reality and as an ideal to be aspired to, as well as acknowledge the contingent and often-arbitrary nature of human relations. While the basic truths of political economy were objective, they had no bearing on the current state of exploitation and injustice in human relations but were nevertheless the key to understanding how to overcome them. This seemingly convoluted epistemological roadmap to human liberation is based on a faith in the just reign of Reason. Indeed, the government of man (based on our arbitrary wills, passions, and desires) instead of reason will never be just. The government of man invites "domination by the arbitrary and willful" while the government of reason invites justice. ${ }^{147}$ Proudhon clearly distinguishes between our human will (under the unjust relations of capitalism and state rule) and Reason. In contrasting the arbitrary will of men and reason, Proudhon invokes anarchy as substituting our "habit of taking man for our rule and his will for our law." He cautions against the "height of disorder" and the "expression of chaos" that

\footnotetext{
${ }^{146}$ Proudhon used the phrase to convey the idea that property is usually sanctioned arbitrarily (i.e., not in accord with reason) and such recognition did not admit the initial "theft" necessitated to realize such a state of affairs (i.e. the current exploitative and unjust nature of political economy). See P.J. Proudhon, ed. Donald R. Kelly and Bonnie G. Smith, What is Property? (Cambridge: Cambridge University Press, 2008).

${ }^{147}$ Hoffman, 71.
} 
reigns in a society governed by men and celebrates the "absence of a master, of a sovereign" where the "sovereignty of will" gives way to the "sovereignty of reason."

It is an unfailing Reason that protects us from arbitrary injustices. According to Proudhon, "Reason, aided by Experience, shows man the laws of nature and of society, and says to him: These are the laws of necessity itself. No man has made them: nobody forces them upon you." ${ }^{, 149}$ It is the interplay between an abstract Reason and everyday experience that guides us to liberation and justice.

Proudhon's theory is thoroughly grounded in everyday living. He considered knowledge to derive from experience. But, there was more to this Proudhonian insistence on experience than simply induction. His consideration of experience always highlighted the idea of process, becoming, and contingency. Proudhon found life to resist fixed and absolute schematization.

"Reality," writes Proudhon, "is inherently complex; the simple never leaves the realm of the ideal, never arrives at the concrete."...In the face of a universe whose "infinities" are "inexhaustible," Proudhon asks us to attend to the "fecundity of the unexpected," which "outstrips any foresight" - the "fecundity of the creative power" of "Nature," whose works are "always new and always unforeseen...a text which cannot be exhausted of conjectures." 150

\footnotetext{
${ }^{148}$ Proudhon, What is Property?, 209.

${ }^{149}$ Proudhon, General Idea of the Revolution, 294.

${ }^{150}$ Proudhon is quoted in Jesse Cohn, Anarchism and the Crisis of Representation: Hermeneutics, Aesthetics, Politics (Selinsgrove: Susquehanna University Press, 2006), 66.
} 
Proudhon thought knowledge of this "text" was not "prior to phenomena," but "discovered in them." By discovering the regular relations and laws in nature we discover the essential rationality of the universe. We can only discover such laws by regular intercourse with the fleeting and contingent experiences of everyday life. However arbitrary or even artificially orderly this kind of knowledge may seem, Proudhon (especially in his later work) scorned those who divorced their theories from daily human experience. $^{151}$

This "rational structure" in Proudhon's theory is not static. "Rational determination is always modifiable and modifying." This "notion of reason and of rationality of existence incorporates an assumption that process is essential to reality, and fixity alien to it." 152 This attitude has political implications. If "process" is essential to reality then a rejection of any fixed status quo becomes logical. So, Proudhon's emphasis on experience reflects the critical importance of flux and ephemerality rather than principled consistency in both politics and epistemology.

This attitude towards change and becoming also implies progress and enthusiasm towards the prospect of enlightenment although Proudhon usually avoids the "naïve optimism common to both his contemporaries and their Enlightenment forebears." Indeed, Proudhon recognized there were many obstacles to progress. ${ }^{153}$ Nevertheless, he never wavered in his rejection of stasis and our urge to freeze the gains of one generation

\footnotetext{
${ }^{151}$ Hoffman, Revolutionary Justice, 7.

${ }^{152}$ Ibid, 8.

${ }^{153}$ Ibid.
} 
for the sake of avoiding an unknown (a progressive unknown for Proudhon) "to come." 154

According to Hoffman, though Proudhon engaged in some of the systematization so popular in nineteenth-century social and political theory he maintained that his philosophy was "not absolute, but insistently non-dogmatic." At times, Proudhon seems to combine an unapologetic rationalism with a suspicion of systemic thought and what he calls "absolutism." Proudhon rejects the absolutism of inflexible conceptual frameworks and systematization of philosophy (positivist thinking in social science was a favorite enemy) just as vociferously as he does the absolutism of the State and the Church. ${ }^{155}$ Nevertheless, Proudhon occasionally lends his voice to a celebration of Reason that overcomes the arbitrary will of others (especially those impositions that are channeled through unjust institutions).

In any case, Proudhon does not entirely dismiss system building. It can serve practical purposes when trying to improve understanding or working towards some goal. However, such utility should not be confused with the nature of reality itself. Though a conceptualized pattern of regularity can improve our rational understanding such "patterns are imposed on reality and not a part of it." ${ }^{156}$ Moreover, he recognized "no

\footnotetext{
${ }^{154}$ Derrida employs the phrase "to come" to mean something similar to what Proudhon meant by progress. However, Proudhon's notion of progress is more heavily steeped in Enlightenment values of liberty and equality. There is a certain affinity between Proudhon's reading of progressive flux and Derrida's understanding of a perpetually contingent "to come" (especially in the context of his thoughts on democracy). For a good explanation of Derrida's notion of "democracy to come" see Matthias Fritsch, "Derrida's Democracy to Come," Constellations: An International Journal of Critical and Democratic Theory, 9:4 (2002), 574-597.

${ }^{155}$ Hoffman, Revolutionary Justice, 232-3.

${ }^{156}$ Ibid, 246.
} 
certainties except moral obligation" and assumed "that no knowledge or concept is final." In Proudhon's philosophy there is a "rejection of the dogmatism and fatalism" of "traditional thought" and of the "positivism born of modern science" yet a thorough appreciation for the utility of generalization and conceptualization to fuel the important liberating effects of an adherence to Reason. ${ }^{157}$

This insistence on non-dogmatism tends to sit uncomfortably with Proudhon's occasional flurries of celebration concerning Reason as well as his accompanying notion of human nature. Proudhon's rebellion against the established order was not a "rejection of the rule of law, but adherence to the higher law of reason" and integral to Proudhon's idea of freedom is the idea of the unimpeded exercise of reason. Proudhon notes, "To be free: the man who is in possession of his reason and of his faculties, who is neither blinded by passion, nor constrained by or impeded by fear, nor deceived by false opinion." ${ }^{158}$ In this sense, Proudhon echoes Plato, Kant, and many other seminal figures in Western thought. However, while the unimpeded exercise of reason does yield the only genuine possibility of freedom Proudhon thinks such an exercise will not reveal immutable truths about the proper ordering of society but rather progressively pave the way to justice.

Much of Proudhonian political theory rests on this idea of freedom. Justly engaging in market transactions, political relationships, and working towards the public interest are all contingent on our ability to be free in the Proudhonian sense. Having no

\footnotetext{
${ }^{157}$ Ibid, 17.

${ }^{158}$ Proudhon quoted in Hoffman, 61.
} 
alternative but to enter disadvantageous transactions because of unequal conditions is bred of those same structures of inequality that impede the exercise of reason. Proudhon sees Reason as the vehicle through which liberation occurs as well as conceives of it as the ultimate end-point (as liberty and equality are always in accord with Reason and vice versa). This is rooted in a principled faith in our ability to autonomously make our own decisions and, given the requisite freedom, have those decisions attuned to Reason.

Like Kant, Proudhon "recognizes no external authority as source of any norm. The rules a man lives by must be entirely internal in origin, stemming from his rational faculties." This is the only way we are able to act morally. This idea of the internal origin of morality also reflects rationality as inherent to human identity precisely in the essentialist vein that much of Proudhon's own thought about justice would reject. Within this frame, equality reflects the fact that we can all reason regardless of how effectively we do so. In other words, justice does not necessarily imply a perfect outcome for Proudhon but rather the possibility of striving for an outcome freely. ${ }^{159}$

In addition to considering the exercise of reason as central to our identity, and despite his weariness over a "new intolerance" of logic and reason, Proudhon did not hesitate to celebrate Reason and to promote the axiom of our "constant, unchangeable nature." ${ }^{160}$ This "essentialist" conception of humankind points to an unashamed embrace of Enlightenment philosophical anthropology. He notes, “....man is moved by an internal attraction towards his fellow, by a secret sympathy which causes him to love, interact,

\footnotetext{
${ }^{159}$ Ibid, 229-230.

${ }^{160}$ Alan Ritter, The Political Thought of Pierre-Joseph Proudhon (Princeton: Princeton University Press, 1969), 27.
} 
and sympathise [sic], so that, to resist this attraction, he must pit his will against his nature."161

In addition to sympathy, Proudhon also thought we are endowed with other uniquely human capacities. Both evil (error, for Proudhon) and good (truth, for Proudhon) are the products of two human faculties, instinct and reflection. As Proudhon puts it "evil is the product of incest between two opposing forces, and good will sooner or later be the legitimate child of their holy and mysterious union."162 Proudhon, like most anarchists, believed in an adaptable nature that varied as circumstances changed. We are capable of great good and great evil and both are products of human instincts and our capacity for reasonable reflection. Proudhon recognized we have egoistic and base instincts and an ability to use reasoning in disheartening ways for horrific ends as well as the capacity for sympathy and an ability to employ reason for great good. However, these instincts and our propensity for reflection were themselves fixed and unchanging while they served us in flexible ways depending on our circumstance.

Among our fixed mental traits Proudhon claims our psychological egoism or, as Alan Ritter describes it, the "propensity of a man to aim for nothing but his own satisfaction. ${ }^{\text {163 }}$ Proudhon claims even apparent instances of altruism can be dismissed as expressions of an incurable egoism. ${ }^{164}$ Likewise, Proudhon sees egoistic hedonism as

\footnotetext{
${ }^{161}$ Proudhon, What is Property?, 172.

${ }^{162}$ Ibid, 194-5.

${ }^{163}$ Ritter, Proudhon, 28.

${ }^{164}$ Ibid, 29.
} 
another inherent human trait. That is, the idea that we get more pleasure from satisfying ourselves rather than others (thereby limiting the potential pleasure derived from altruism). But our nature is also mixed for Proudhon; while undeniably pugnacious we are also "the most sociable of animals." 165

It is in accordance with our mixed (yet seemingly unchanging) natures that Proudhon envisions anarchist society. It is a society where personal property is respected but the means of production should be owned communally, where societal dominion is unacceptable but authority in the home is tolerated, and where we can be just as easily dominated by the ambition of others as by our own cognitive and moral limitations and excesses. Indeed, Proudhon notes the dangers of both "internal" and "external" restraint. Not only does he challenge the restrictions posed by "duly enacted laws, social pressures, religious codes, economic, and even physical forces, as by the arbitrary wills of other people," but he also presupposes the "divided self" by pointing to the "internal restraint" that includes "not just the tyranny of the passion, but control by conscience."166

Despite admitting the authoritarian potential of, at least, parts of our selves, Proudhon has no qualms about accepting the potential for domination in our most privileged faculty. In fact, he privileges reason to the point where he considers it an antidote to the caprice of injustice in the social, economic, and political realms. In challenging the age-old notion of property he notes,

\footnotetext{
${ }^{165}$ Ibid, 31.

${ }^{166}$ Ibid, 20-1.
} 
Finally, as to the time required for prescription, it would be superfluous to show that the property in general cannot be acquired by simple possession for ten, twenty, a hundred, or a hundred thousand years, and that, so long as there exists a human head capable of understanding and contesting the right to property, this right will never be prescribed. For it is not a principle of jurisprudence or an axiom of reason but only an accidental and contingent fact. One man's possession may prescribe against that of another man, but just as the possessor cannot prescribe against himself, so reason has always the capacity to reform and revise itself, for the past is not binding on the future. Reason is external and always the same. The institution of property, the work of uninformed reason, may be abrogated by a more informed reason. Thus, property cannot be established by prescription. This is so certain and so true, that it is the basis of the maxim that in matters of prescription a legal error may not profit anyone. ${ }^{167}$

Likewise, it is this external marker of Reason that should guide the proper administration of public affairs. Proudhon notes,

Every question of domestic politics must be decided by departmental statistics; every question of foreign politics is an affair of international statistics. The science of government rightly belongs to one of the sections of the Academy of Sciences, whose permanent secretary is necessarily prime minister; and since every citizen may address a memoir to the Academy, every citizen is a legislator.

${ }^{167}$ Proudhon, What is Property?, 209. 
But as the opinion of no one is of any value until its truth has been proven, no one can put his will in the place of reason-no one is king. ${ }^{168}$

In other words, Proudhon considers governing a science. He appeals to the eternal laws of Reason as guides to the proper mode of governmental administration. This sits uneasily with his rejection of government and his overall anti-authoritarianism. The fact is that Proudhon celebrated Reason in ways that often seemed to contradict his general suspicion of arbitrary authority.

In any case, while celebrating Reason as both an ideal and a faculty, Proudhon also makes an "essentialist," albeit ambivalent, case for a human nature (based on our incurable egoism and inherent sociability) that both anchors and attunes itself to Reason. Likewise, this same varied human nature informs our understanding of moral authority. While Proudhon conveys that we are both egoistic and sociable he does not think history really began this way. "It is only abstractly" that man "can be considered in a state of isolation and with no law but egoism." "169 However, scholars like Ritter contend,

Perhaps his claims to the contrary are best interpreted as experimental hypotheses. Proudhon may assume that if he can show the possibility of liberation for men who start without social ties and with a selfish morality, he will also have proved liberation possible under more conducive initial conditions. ${ }^{170}$

\footnotetext{
${ }^{168}$ Ibid.

${ }^{169}$ Proudhon is quoted in Ritter, Proudhon, 37.

${ }^{170}$ Ibid, 38.
} 
The idea is that these assumptions would avoid common utopian criticisms by not relying on an "enlightened self-interest" to argue for reform or revolution. ${ }^{171}$ Nevertheless, Proudhon himself also recognizes our sympathy for others and that to resist this fellow feeling is unnatural.

In light of our egoism and sociability, Proudhon found anarchist social organization to harmoniously overcome as well as cohere with our nature. In this view, blaming societal "antinomies" on either human nature (as in Christianity) or on the depravity of society (as in Rousseau or the utopian socialists - Saint-Simon, Owen, Fourier, and their disciples) is seen as simplistic and misguided to Proudhon. ${ }^{172}$

Moreover, in addition to highlighting our varied natures, Proudhon's stance on moral authority is ambivalent. On the one hand he has a deontological ethical stance. According to Ritter, "An action is right, he [Proudhon] maintains, only if it conforms to the specifications of an ultimate norm, and regardless of the actual or expectable results that follow from adhering to it." For Proudhon, there are such things as intrinsically good actions which are "'indispensable, imperative, often onerous, indifferent to self-interest, concerned only with what is right and binding, however unprofitable circumstances make the former, however disastrous they make the latter.",173

Yet, Proudhon also seems to embrace a kind of moral constructivism by insisting that "the last word in ethical disputes belongs to the adversaries themselves" while

\footnotetext{
${ }^{171}$ Ibid, 31-2.

${ }^{172}$ Proudhon, The Philosophy of Misery, 403-6.

${ }^{173}$ Ritter, Proudhon, 67.
} 
holding to a subjectivist position, which again appeals to the authority of Reason. As Proudhon puts it,

Every man should decide for himself, at least about the specific obligations entailed by first principles. 'In the last analysis, each individual is the judge of right and wrong and is empowered to act as an authority over himself and all others. If I decide for myself that something is unjust, it is futile for the prince or the priest to call it just and order me to do it: it remains unjust and immoral...And conversely, if I decide inwardly that something is just, it is futile for the prince or the priest to claim to forbid me to do it: it remains just and moral. ${ }^{174}$

Both beliefs, while seemingly at odds, point to a respect for freedom of choice, free agreement, and autonomy. For Proudhon, it is only with others that we can decide for ourselves. This is not a kind of moral relativism, rather it is a recognition that morality is only recognized and normative belief only justified when in accordance with Reason and Reason is itself always a reflection of our freely made choices and agreements. Whether a construction by the agents involved, socio-economic context, or physical reality, we are obliged to choose for ourselves and Proudhon takes it that we can.

In claiming that all "questions of legislation and politics are matters of science, not of opinion" Proudhon recognizes that a simple recognition of truth via Reason is enough to compel justice and legality. ${ }^{175}$ Nevertheless, he firmly believes that all systems

\footnotetext{
${ }^{174}$ Proudhon quoted in Ritter, 67-8.

${ }^{175}$ Proudhon, What is Property?, 209.
} 
are equally opposed to progress. ${ }^{176}$ How then can we reconcile these two points of view if we take a strict adherence to Reason as a system of thought?

Proudhon thought of an adherence to Reason as self-legitimating. Much like Habermas, who believes in the self-validating role of reason, ${ }^{177}$ Proudhon sees our most prized faculty, and the ideals derivative of it, as grounded in an ecosystem of selfreverence, self-reference, and auto-critique while authority, in any manifestation, is anathema to Reason for Proudhon. The generational authority of parents, the authority patriarchy and physical force in what Proudhon calls barbarous people, faith among sacerdotal peoples, primogeniture or caste in aristocracies, by lot or number as in Rousseau's political thought - none of it can stand the scrutiny of reason. Unthinking submission is the only option for these traditional modes of authority; if any of these types of authority is met by reason their principles crumble. "Authority, like Liberty, recognizes only itself as a principle" but is, curiously, still imposed through "the investiture of Power."

However nuanced Proudhon's conception of the authority of Reason might be (especially in his What is Property? and General Idea of Revolution in the Nineteenth Century), it is clear that his thought becomes more sophisticated and less unthinkingly

\footnotetext{
${ }^{176}$ Proudhon, General Idea of the Revolution, 80.

${ }^{177}$ Habermas couches the self-validating role of reason plays in Modernity's ability to create normativity out of itself. He also distinguishes between what he considers the impoverished view of instrumental rationality in Max Horkheimer and Theodor Adorno's Dialectic of the Enlightenment and a more holistic understanding of reason as integral to the discourse of modernity. See Jürgen Habermas, The Philosophical Discourse of Modernity: Twelve Lectures (Cambridge: MIT Press, 2000). See especially lectures 1, 2, 5, 11 , and 12

${ }^{178}$ Proudhon, General Idea of the Revolution, 137-8.
} 
reverential to our most prized faculty (and the auxiliary notions that usually sustain it) as he matures. This is tied to his evolving understandings of static philosophizing in an everchanging world. Proudhon's denial of stasis and embrace of the dynamic is more evident in his later work (especially The Philosophy of Poverty and De la Justice dans la revolution et dans l'Eglise). In these works he is keen to not only defend anarchism as a response to rigid social organization but also to attack absolutism in all its forms including intellectualism and other dogmatisms.

\section{The Anarchist Embrace of Anti-Intellectualism and Modernism}

Many have echoed the heart of the anarchist attitude towards Reason. From Hegel's politics of “inclusivity" to Habermas' communicative rationality, the idea that we could non-coercively attune ourselves to truth and a politics grounded in freedom (of course how this freedom would materialize is the subject of continued debate) is central to not only anarchism but to modernity itself. ${ }^{179}$ This attitude is, first and foremost, a self-critical and anti-authoritarian appreciation for the importance of knowledge and its centrality to freedom and justice.

The means by which this "knowledge" is deployed informs both what constitutes knowledge and the means of arriving at it. Anarchists of all stripes would agree that our

\footnotetext{
${ }^{179}$ William Connolly describes Hegel's "politics of inclusivity" as follows: "It is part of the essence of humanity to seek truth by pressing onward to agreement, and the highest form of politics, to be realized finally in the modern period, is one where the sphere of fundamental agreement is all-inclusive, virtue is highly developed, rationality flourishes and freedom reigns. Put another way, the implicit purpose of human history is to eliminate otherness - all that escapes knowledge, reason, and normality - by pressing onward to agreements which assimilate it to higher forms of knowledge, reason and normality. The politics of inclusivity engenders the assimilation of otherness." See William Connolly, Political Theory and Modernity (Oxford: Blackwell, 1988), 87. Communicative rationality is detailed in Jürgen Habermas, The Theory of Communicative Action, Volume 1: Reason and the Rationalization of Society (Boston: Beacon Press, 1984).
} 
modern world is governed by our hubristic drive to command and control nature. The idea that "knowledge is power" is reflective of this modern understanding of knowledge oriented towards mastery and away from wonder. ${ }^{180}$ This shift in emphasis attempts to harness the seemingly limitless power of Reason, and reinforces the "iron cage" described by Weber as a consequence, and leads to domination in several spheres of life, including the intellectual.

This ironically positions us to fail more intensely in the pursuit of freedom such a drive promises. Any "absence of control is experienced as unfreedom and imposition: the experiences of alienation, estrangement, repression, authoritarianism, depression, underdevelopment, intolerance, powerlessness and discrimination thereby become extended and intensified in modern life." ${ }^{181}$ Both Godwin and Proudhon recognized this danger. In an attempt to circumvent its effects, Godwin and Proudhon gradually came to embrace a "soft" rationalism that admitted Reason's place as our guiding faculty but recognized the dangers of celebrating it and therefore rejected the predictable intellectualism that would follow.

Thinking otherwise than Reason remained a difficult endeavor for both Godwin and Proudhon as many of their supporting concepts and ideals rested on a firm appreciation for the same. Our ability to freely engage one another and construct a mode of social organization free from coercion required Reason as the primary means and guiding principle. According to Godwin and Proudhon, Reason had the ability to justify

\footnotetext{
${ }^{180}$ In the Western tradition, the dictum "knowledge is power" is attributed to Francis Bacon in his Meditationes Sacrae (1597).

${ }^{181}$ Connolly, Political Theory and Modernity, 2.
} 
itself and embodied the kind of "self-critical reassurance" so typical of modernity and critical to anarchist practice. ${ }^{182}$

Nevertheless, Reason and the auxiliary notions usually employed to support it themselves became objects of critical consideration for both Godwin and Proudhon. They both came to rely less heavily on Reason as the exclusive framework from which freedom and justice would derive and instead embraced a multi-faceted appreciation for uniquely human faculties (like reason) and the romanticist impulses and counterEnlightenment thinking (e.g., an appreciation of our "domestic affections" and "sympathy") which they considered central to both freedom, justice, and truth.

Later anarchist thinkers shared this critical view of intellectualism but came to embrace it from the start. In other words, intellectually, while Godwin and Proudhon progressively became less like hedgehogs and more like foxes, ${ }^{183}$ other classical anarchist thinkers, most notably Mikhail Bakunin and Peter Kropotkin, were always more diverse in their philosophical inspirations and less dogmatic in their appreciation of Reason. In the next chapter I will interrogate how Bakunin and Kropotkin came to their critical embrace of Reason and how they always kept the ideal (and the accompanying intellectualism) at arms length.

\footnotetext{
${ }^{182}$ Habermas, The Philosophical Discourse of Modernity, 51.

${ }^{183}$ See Isaiah Berlin's essay “The Hedgehog and the Fox” in Russian Thinkers (New York: Penguin Books, 2008), 24-92.
} 


\section{Chapter 3}

\section{Reason, Science, and Anti-Intellectualism in Mikhail Bakunin and Peter Kropotkin}

The pursuit of scientific knowledge is as central to the anarchist endeavor as is the fight against the state. The so-called classical anarchists of the $19^{\text {th }}$ century, especially Mikhail Bakunin and Peter Kropotkin celebrated the scientific method and its ability to accurately and consistently facilitate an understanding of reality and contribute knowledge that would expedite anarchist revolution. While celebrating the liberating aspects of science (and the usually accompanying ideal of Reason), both Bakunin and Kropotkin diagnosed a kind of intellectual monomania that relied exclusively on Reason and science (and the auxiliary notions that usually sanctify them) to bring about revolution. They were wary of hierarchically institutionalized forms of scientific discovery, the dogmatic insistence on the univocity of rational thought, and the intellectualism and estrangement from quotidian tasks bred of a firm division of intellectual from manual labor incited by such monomania.

Mikhail Bakunin was not a doctrinaire, systematic thinker. As Bakunin declared, "I cleave to no system, I am a true seeker." 184 Bakunin thought systematicity impoverished the value of lived experience and education itself. ${ }^{185}$ While systematic thought may serve utilitarian ends, these ends are not inherently valuable. In a rejection of "scientism" and "instrumental rationality," Bakunin forcefully scorned the runaway

${ }^{184}$ Bakunin quoted in E.H. Carr, Michael Bakunin (New York: Vintage Books, 1937), 175.

${ }^{185}$ Paul Avrich, Anarchist Portraits (Princeton: Princeton University Press, 1988), 5-6. 
self-legitimating character of scientific "progress" and technological advances that later scholars would identify as the genesis of horrors on a vast scale. ${ }^{186}$ Indeed, as Paul Avrich put it, Bakunin disdained intellectuals who sacrificed "real life on the alter of scholastic abstractions. ${ }^{187}$

Peter Kropotkin equally disdained this kind of scientism and the intellectualism that predictably followed. While it is clear that Kropotkin accepts the epistemic authority of science, he does not embrace the accompanying scientism and intellectualism that is central to the ideological frameworks of many systems of domination. According to Kropotkin, anarchism itself is anathema to any institutionalized, scientific, or philosophical rendering of social relations. While Kropotkin did rely on evidence from nature (e.g., the behavior of animals) to inform his brand of anarchism, especially his theory of mutual aid, he clearly delineated the limits of such intellectual endeavors as divorced from our lived experience. Once our lived experiences are filtered through the lens of ideology, science, and philosophy, or are academically catalogued or institutionally itemized, they lose their immediacy. According to Kropotkin, it is this immediacy that is steeped in the everyday experience of working class and poor people that reflects anarchism. ${ }^{188}$ In this sense, Kropotkin was a thorough anti-authoritarian and anti-intellectual. Nevertheless, like his Enlightenment predecessors, Kropotkin saw the

\footnotetext{
${ }^{186}$ Perhaps the most theoretically forceful account of how "instrumental rationality" paved the way for atrocities is Max Horkeimer and Theodore Adorno, The Dialectic of The Enlightenment, ed. Gunzelin Schmid Noerr, trans. Edmund Jephcott (Stanford: Stanford University Press, 2002).

${ }^{187}$ Mikhail Bakunin, God and the State (New York: Dover Publications, 1970), viii.

${ }^{188}$ Peter Kropotkin, Anarchism: A Collection of Revolutionary Writings, ed. Roger N. Baldwin (Mineola: Dover Publications, 1970), 146.
} 
liberating potential of science and our faculty of reason while recognizing the dangers of its institutionalized forms and an obsession with their purity and preeminence.

Both Bakunin and Kropotkin shared a suspicion of concentrations of political, economic, and cultural power. Prominent among these concentrations and something that intersects all these spheres are centers of ostensible "intellectual authority." They were both wary of scientific associations and universities not because their ostensible goals were contrary to anarchist ideals but rather because their increasingly hierarchical structure sometimes facilitated the authoritarian tendencies contrary to these ideals and encouraged a worship of their guiding mantra of science and Reason.

Bakunin and Kropotkin reflected the Russian anarchist movement of the $19^{\text {th }}$ century that "manifested a deep seated distrust of rational systems and of the intellectuals who constructed them." 189 Anarchist historian Paul Avrich notes, "While inheriting the Enlightenment's belief in the inherent goodness of man, the Russian anarchists generally did not share the faith of the philosophes in the power of abstract reason." ${ }^{190}$ Both Bakunin and Kropotkin rejected the supposed "scientific" theories of history and society (reacting mainly to the Marxists) as "... artificial contrivances of the human brain which served only to impede the natural and spontaneous impulses of mankind." 191

This emphasis on spontaneity, fluidity, and contingency does not pin Bakunin and Kropotkin against all systematic scientific and rational thought. They promoted a healthy

\footnotetext{
${ }^{189}$ Paul Avrich, "Anarchism and Anti-Intellectualism in Russia," Journal of the History of Ideas, Vol. 27, No. 3 (1966): 381.

${ }^{190}$ Ibid, 381.

191 Ibid.
} 
suspicion of all "intellectual authority" in the same way they challenged authority vested in the state or other forms of institutionalized hierarchy. What this emphasis on flexibility does do is recognize our ability to employ these rational and scientific methods for our own ends. For anarchists like Bakunin and Kropotkin, these ends were the liberation of humankind. Insofar as the scientific method and the ideal of Reason contributed to such ends they were employed readily. However, whenever these means stifled or contradicted the march towards liberation they were combated at every turn.

\section{Mikhail Bakunin as Anti-Authoritarian Anti-Intellectualist}

Most of Bakunin's writings exhibit a clear contempt for what he considered the authoritarian machinations of Karl Marx. ${ }^{192}$ The "dictatorship of the proletariat" and the accompanying social, cultural, and political institutions needed to govern such a revolutionary state struck Bakunin as contrary to his ideals of liberty. While the Marxists may have discovered the laws of political economy, their scientific pretension in translating those laws into revolutionary action struck Bakunin as elitist and totalitarian. According to Bakunin, it was not the role of an enlightened revolutionary vanguard but rather the people as a whole (perhaps with the input of philosophers, intellectuals, and political theorists) to make revolution.

Intellectuals were to have an auxiliary role in the revolution. The revolution needed to be made by the people themselves. Bakunin thought it would be messy and that this was a good thing. The freedom to mature the revolution in fits and starts, to

\footnotetext{
${ }^{192}$ Despite Bakunin's supposed authorship of the pamphlet, I have excluded an analysis of Catechism of a Revolutionary since it is usually attributed to Russian nihilist revolutionary Sergei Nechaev. See Mark Leier, Bakunin: The Creative Passion (New York: St. Martin's Press, 2006), 201-224.
} 
equivocate and correct, to quibble and overcome, was all a necessary part of a revolutionary process that would never quite culminate in some final stage of history or complete overcoming of injustice. For Bakunin, this freedom stood in contradistinction to the determinist and teleological worldview of the Marxists. Bakunin and the anarchists did not share Marx's theory of history that crowned the successful dictatorship of the proletariat and eventually dissolved all class distinctions because it seems to overlook the importance of individual agency and creativity in a revolutionary process seemingly drowned in historical necessity. Rather, they considered history a reflection of the constantly negotiated roles and resistance integral to not only class conflict but also individual flourishing and the free association of persons and groups.

Bakunin rejected the intellectualism of ossified centers of social, cultural, and political thinking. Academia, scientific associations, and governmental agencies dedicated to the dissemination of culture or knowledge were all potentially dangerous according to Bakunin. While they ostensibly furthered the aims of science (i.e., the search for truth) they also embodied structures of domination that threatened free association and the individual liberty Bakunin cherished. While the goal of science is certainly noble, a government by science or in the service of science posed a threat to liberty because the hierarchy inherent in government necessarily excluded full participation. Moreover, such a government would substitute reasons of state with reasons of science. In this case, for Bakunin, the arbitrarily authoritative and unaccountable idol remains only under a different guise. He argued such a government and the associations that could potentially comprise it are divorced from the true ends of revolutionary anarchism. Most 
importantly, though perhaps facilitating access to truth, such a government would obstruct our liberty to recognize this truth.

It is worth quoting Bakunin at length. He notes, "The liberty of man consists solely in this: that he obeys natural laws because he has himself recognized them as such, and not because they have been externally imposed upon him by any extrinsic will whatever, divine or human, collective or individual.” He continues,

Suppose a learned academy, composed of the most illustrious representatives of science; suppose this academy charged with legislation for and the organization of society, and that, inspired only by the purest love of truth, it frames none but the laws in absolute harmony with the latest discoveries of science. Well, I maintain, for my part, that such legislation and such organization would be a monstrosity, and that for two reasons: first, that human science is always and necessarily imperfect, and that, comparing what it has discovered with what remains to be discovered, we may say that it is still in its cradle. So that were we to force the practical life of men, collective as well as individual, into strict and exclusive conformity with the latest data of science, we should condemn society as well as individuals to suffer martyrdom on a bed of Procrustes, which would soon end by dislocating and stifling them, life ever remaining an infinitely greater thing than science.

The second reason is this: a society which should obey legislation emanating from a scientific academy, not because it understood itself the rational character of this legislation (in which case the existence of the academy would 
become useless), but because this legislation, emanating from the academy, was imposed in the name of a science which it venerated without comprehending such a society would be a society, not of men, but of brutes...It would surely and rapidly descend into the lowest stage of idiocy. ${ }^{193}$

Indeed, Bakunin considered the institutions that serve the perpetuation and safeguard the rigor of science to tend towards intellectual authoritarianism or at the very least to discourage the independent exercise of reason.

It was not only the institutionalized forms of science that bore Bakunin's criticism. Science itself was not free of criticism. While he saw himself laboring for truth and considered Reason the key to unlocking the truths of nature and society, he also saw a danger in limiting emancipation to our limited capacity to grasp truth in its entirety. Our limitations as finite thinking beings are aided by the scientific endeavor in that we can accumulate knowledge in the aggregate and "stand on the shoulders of giants" but by the same token we run the risk of being made prisoners of an all-encompassing ideology that promises to expedite thinking. ${ }^{194}$ In the face of our limited individual potential science becomes a useful tool for collective liberation but it should not be turned into just another belief system. Bakunin is clear in considering science a method to discover particular facts and not a comprehensive worldview. Bakunin notes,

\footnotetext{
${ }^{193}$ Bakunin, God and the State, 30-1.

${ }^{194}$ Martin Heidegger later understood this dilemma and how science and reason alone do not constitute thinking. See Martin Heidegger, What is Called Thinking? (New York: Perennial, 2004).
} 
Vast as the world itself, it [science] exceeds the capacities of the individual man, even though he may be the most intelligent of all humans. No one is capable of encompassing science in all its universality, and in all its infinite details. He who clings to the general and neglects the particular lapses therewith into metaphysics and theology - for the scientific generalization differs from the generalization in theology and metaphysics in that the former is built not upon an abstraction from all particulars, as is the case with metaphysics and theology, but, on the contrary, solely by relating the particulars into an ordered whole. ${ }^{195}$

Bakunin is clear in his admiration of the ability of science to further progress in our quest for truth and knowledge. It facilitates the aggregate accumulation of knowledge while avoiding the grandiose metaphysical oversimplifications that ostensibly facilitate access to comprehensive belief systems. While it may be easy to hold beliefs through theology, ideologies, or sweeping philosophical systems that explain the world in ostensibly accessible ways, these methods necessarily avoid the kind of particularities that actually constitute knowledge.

While the scientific method effectively allows us to discover truths, the metaphysical systems employed by philosophers and theologians hinder our access to knowledge. It is impossible to grasp the ordered whole of the universe in any intellectually rigorous way and this is what makes science so useful. According to Bakunin, sweeping intellectual explanations and rationalizations of reality, that are readily available in theology and metaphysical thinking, do an injustice to the complexity

\footnotetext{
${ }^{195}$ Mikhail Bakunin, ed. G.P. Maximoff, The Political Philosophy of Mikhail Bakunin: Scientific Anarchism (New York: The Free Press, 1953), 72. The italicized emphasis is Bakunin's.
} 
of our world. Science on the other hand is able to demystify reality in all its concrete particularities by avoiding overarching and necessarily oversimplified intellectual systematizations. Science deals with particular questions, problems, and puzzles and for this very reason is ill-suited to answer the overarching questions that metaphysics, ideology, and philosophy easily tackle.

While Bakunin is clear regarding the advantages and usefulness of science he is also wary of its idolization. There is also a clear disdain for the fetishizing of science in Bakunin's work. Once the idea of science is elevated to the position of ideology, metaphysics, or philosophy its explanatory power is weakened and its institutional manifestations become authoritarian. For Bakunin, the worship of science becomes just as dangerous as the worship of God once it is celebrated as the answer to all of our ills. Bakunin thought once science itself was considered a belief system that promised to eventually solve all our problems human beings would easily be sacrificed at the "alter of abstractions" for the sake of an imagined progress in its name.

This is consistent with Bakunin's insistence that authentic revolutionary action must sprout from the people themselves and not their so-called leaders. It is the particular, local, and contingent desires and wisdom of the people that fuels revolutionary action. Sweeping solutions to public problems (in Bakunin's day a critique of Marx's "dictatorship of the proletariat" was especially pronounced), however democratic they may seem, did not allow for the free organization of people from the bottom up without "interference, tutelage, or coercion from above." Instead, these solutions, no matter how republican or supposedly democratic, organized the masses from the top down and were 
headed by "an educated and thereby privileged minority which supposedly understands the real interests of the people better than the people themselves." 196

Bakunin's unshakable faith in our ability to perceive our own interests and our rational capacity to discern the truth given access to adequate information is central to his anarchism and anti-intellectualism. He, like Godwin, Proudhon, and many Enlightenment thinkers before them, trusted our "private judgment" to adequately arrive at truth. That is, they believed we were essentially capable of exercising our most esteemed faculty in the service of truth so long as the obstacles to its free exercise were overcome. However, such faith in our most prized faculty did not translate into subservience to Reason itself. Nor did it translate into an absolute deference to those who claim mastery, specialization, or expertise in any endeavor where intellectual authority or expertise is called for.

Bakunin clearly distinguished between hostility towards intellectual pursuits and hostility towards intellectuals, between a derision of education or science and distaste for a privileged education and scientism, as well as between an aspiration to intellectual rigor and an appeal to intellectual authority. Bakunin sums it up best in God and the State when he notes,

In the matter of boots, I refer to the authority of the bootmaker; concerning houses, canals, or railroads, I consult that of the architect or engineer. For such or such special knowledge I apply to such or such a savant. But I allow neither the bootmaker nor the architect nor the savant to impose his authority upon me. I

\footnotetext{
${ }^{196}$ Mikhail Bakunin, Statism and Anarchy, ed. Marshall Shatz (Cambridge: Cambridge University Press, 2005), 24.
} 
listen to them freely and with all the respect merited by their intelligence, their character, their knowledge, reserving always my incontestable right of criticism and censure. I do not content myself with consulting a single authority in any special branch; I consult several; I compare their opinions, and choose that which seems to me the soundest. But I recognize no infallible authority, even in special questions; consequently, whatever respect I may have for the honesty and the sincerity of such or such an individual, I have no absolute faith in any person. Such a faith would be fatal to my reason, to my liberty, and even to the success of my undertakings; it would immediately transform me into a stupid slave, an instrument of the will and interests of others. ${ }^{197}$

Bakunin makes clear that were he to follow another's guidance on intellectual or political matters it would be because it was "imposed" by his own "reason." Moreover, he would give such guidance as much as he received it. Such, he says, "is human life." He continues, "Each directs and is directed in his turn. Therefore there is no fixed and constant authority, but a continual exchange of mutual, temporary, and, above all, voluntary authority and subordination., ${ }^{, 198}$ The idea of intellectual authority itself is always being negotiated and should not stand outside the relations of "voluntary authority and subordination" that comprise the anarchist ideal. Bakunin notes,

This same reason forbids me, then, to recognize a fixed, constant, and universal authority, because there is no universal man, no man capable of grasping in that

\footnotetext{
${ }^{197}$ Mikhail Bakunin, God and the State (Mineola, New York: Dover Publishing, 1970), 32.

${ }^{198}$ Ibid, 33.
} 
wealth of detail, without which the application of science to life is impossible, all the sciences, all the branches of social life. And if such universality could ever be realized in a single man, and if he wished to take advantage thereof to impose his authority upon us, it would be necessary to drive this man out of society, because his authority would inevitably reduce all the others to slavery and imbecility. I do not think that society ought to maltreat men of genius as it has done hitherto; but neither do I think it should indulge them too far, still less accord them any privileges or exclusive rights whatsoever; and that for three reasons: first, because it would often mistake a charlatan for a man of genius; second, because, through such a system of privileges, it might transform into a charlatan even a real man of genius, demoralize him, and degrade him; and, finally, because it would establish a master over itself. ${ }^{199}$

While rallying against the dangers of top-down organizational and intellectual schemes he points to the dangers and corrupting influences of hierarchy and privilege on our natures (however noble or genius they may be).

According to Bakunin, hierarchy and privilege corrupt our "naturally social and communal" instinct. Contrary to Proudhon's varied view of humankind (the idea we can be both unapologetically egoist as well as the most sociable of creatures), Marshall Shatz, in his introduction to Statism and Anarchy, describes Bakunin's view on human nature as instinctually social and communal. He notes,

${ }^{199}$ Ibid, 33-4. 
Bakunin believed that social solidarity, a deep-rooted social and communal instinct, was an innate feature of human nature. If it failed to manifest itself consistently in contemporary society, that was only because it had been suppressed, or distorted, by the artificial structure of the state. To create a new and better society, therefore, did not require the reeducation of its inhabitants or the transformation of human nature, but only the release of the masses' pent-up natural instincts and social energies by destroying the institutions thwarting them. $^{200}$

Nevertheless, to complement this seemingly axiomatic view of human beings as social creatures, Bakunin is also quite skeptical of the ontological underpinnings that ground such a theory. In this context, he calls into question the authority of what he calls "metaphysics," and "scientism." According to Bakunin,

By "metaphysicians" we mean not just the followers of Hegel's doctrines...but also positivists and in general all the present-day worshippers of the goddess science; all those who by one means or another (if only by a very diligent but necessarily always imperfect study of the past and present) have created for themselves an ideal social organization into which, like new Procrustes, they want to force the life of future generations whatever the cost; in short, all those who, instead of regarding thought or science as one of the necessary manifestations of natural and social life, take such a narrow view of that poor life that they see in it

\footnotetext{
${ }^{200}$ Bakunin, Statism and Anarchy, xxxiii.
} 
only the practical manifestation of their own thought and their own always imperfect science.

He continues, "Metaphysicians or positivists, all these knights of science and thought, in the name of which they consider themselves ordained to prescribe the laws of life, are reactionaries, conscious or unconscious. ${ }^{201}$ In other words, the very philosophical foundations that ground the enterprise of discovering humankind's social nature, the very underpinnings of any scientific categorization of human beings as social or anti-social, and the very ontological presuppositions that Bakunin makes are at odds with the spirit of his skepticism towards the Procrustean tendencies of the metaphysicians. While he notes that "thought and science" are two of the "necessary manifestations" of "natural and social life" he also warns against taking these manifestations as a reflection of a particular, subjective, point of view, or a reflection of a particular worldview or science itself (especially scientific reductionism or an omniscient Reason itself as a worldview).

Yet, at times, Bakunin seems to echo Hegelianism and the notion that "the rational alone is real." Paul McLaughlin references Bakunin on this issue. In commenting on Bakunin's philosophy of nature he notes

In a sense, then, nature is the field of the possible or, we might say, the causable which is the logical; its limit is the uncausable or the impossible - the illogical. In other words, 'All that is natural is logical, and all that is logical has already been

${ }^{201}$ Ibid, 133. 
realized or is bound to be realized in the natural world, including the social world. ${ }^{202}$

Despite McLaughlin's Hegelian reading of Bakunin, Bakunin disdained an overreliance on Reason and the intellectualism it tends to breed. Such an overreliance was inimical to the concrete changes needed to forge egalitarian and free relationships along non-hierarchal and participatory lines. Bakunin equated intellectualism with reactionary politics precisely because it tended towards authoritarianism and the worst excesses of privilege. Likewise, the corresponding veneration of science, or scientism, evacuated all meaning from social existence. Bakunin notes,

Only general scientific education will become common property, particularly a familiarity with scientific method as a way of thinking, that is, of generalizing facts and drawing more or less correct conclusions from them. But there will always be very few encyclopedic minds, and, therefore, learned sociologists. Woe to mankind if thought ever became the source and sole guide of life, if science and learning began to govern society. Life would dry up, and human society would be turned into a dumb and servile herd. The government of life by science could have no other result than to turn all mankind into fools.

He continued,

We revolutionary anarchists are proponents of universal popular education, liberation, and the broad development of social life, and hence are enemies of the

\footnotetext{
${ }^{202}$ Paul McLaughlin, Mikhail Bakunin: The Philosophical Basis of his Anarchism (New York: Algora Publishing, 2002), 104.
} 
state and of any form of statehood. By contrast to all metaphysicians, positivists, and scholarly or unscholarly worshippers of the goddess science, we maintain that natural and social life always precedes thought (which is merely one of its functions) but is never its result. Life develops out of its own inexhaustible depths by means of a succession of diverse facts, not a succession of abstract reflections; the latter, always produced by life but never producing it, like milestones merely indicate its direction and the different phases of its spontaneous and self-generated development. ${ }^{203}$

As opposed to an overreliance on Reason and the intellectualism it usually breeds, Bakunin favored a widely accessible and integrated education that would become the "common property of all" (as opposed to the patrimony of a privileged few) and emphasize both "science and handicrafts" (as opposed to the "hollow abstractions of religion, metaphysics, and sociology"). ${ }^{204}$

This chiding of abstractions has a philosophical and a practical component. Philosophically, abstractions do not facilitate the kind of thinking that serves the aggregate accumulation of knowledge (as opposed to the scientific method which provides the tools by which individuals can accumulate knowledge within scientific communities and then share these with the general public). Practically, a focus on mental labor as opposed to physical labor subtracts from Bakunin's revolutionary goals by

\footnotetext{
${ }^{203}$ Bakunin, God and the State, 135.

${ }^{204}$ Paul Avrich, The Russian Anarchists (Princeton: Princeton University Press, 1967), 94.
} 
making potential revolutionaries either intolerant of or incompetent in the everyday tasks (both menial and skilled) necessary for the triumph of the revolution.

The only way we make life is by creatively constructing it and not speculating on it. In other words,

...what Bakunin rejects is a certain kind of philosophy, a kind he associates with figures whom, in part, he admires (e.g., Marx and Comte); that is, systematic and theologistic philosophy and, especially, philosophy which claims to have the future within its speculative sight. ${ }^{205}$

This rejection of "speculation" and a focus on lived experience is grounded in what can be called Bakunin's naturalism or a "naturalistic account of the structure of being and reality." ${ }^{206}$ While Marx is also well known for his similar idea of philosophical materialism (understood both in terms of the idea that life determines consciousness and the concrete everyday experience of the working class), Bakunin still thought Marx elevated his theory to futile abstractions that would not serve the cause of revolution. Indeed, Bakunin's “naturalism” does not correspond to Marx's materialism. While Marx's materialism is based, in part, on the general idea that our material conditions of life determine our consciousness (consciousness defined specifically as the ideological or philosophical effects of our material conditions), Bakunin considered our "consciousness" involved more than simply a deterministic relationship between our material conditions and our ideas, inclinations, and philosophical outlook. While Bakunin

\footnotetext{
${ }^{205}$ McLaughlin, 13.

${ }^{206}$ Ibid, 1.
} 
embraced an empiricist Enlightenment-inspired naturalism he did not ascribe any kind of ideological or teleological component to his empiricism as did Marx. While Marx's historical materialism is rooted in ideological and political theoretical concerns, Bakunin's naturalism is epistemic.

Moreover, Marx famously thought human nature evolved as the modes of production evolved, though we had innate qualities like intelligence, creativity, and emotions, material conditions and social relations would, to a large degree, influence how our nature manifested itself. Bakunin, instead, thought that we have a communal nature that is manifested in our individual exercise of liberty whereby we act "naturally and consequently freely" by "not exploiting" our neighbors, thereby allowing each other to "live naturally and freely." Essentially, “one individual's freedom serves as a confirmation and extension of another.” Indeed, as Bakunin notes, “... collective liberty and prosperity exist only so far as they represent the sum of individual liberties and prosperities."

Bakunin operated

...within the naturalistic framework established by the empiricist current of the Enlightenment. Humans are conceived as embodying a permanently fixed nature with behavior basically determined by natural laws. This state of affairs is then identified with what is good. However, when coercion enters into the relations 
among people, we enter the realm of the unnatural. We are alienated from our natural condition and we lose our freedom. ${ }^{207}$

While in Marx our idea of what is "good" is itself morphed according to changes in the modes of production, Bakunin thought what is good is already present before any consideration or influence of coercive relations within certain modes of production. For Bakunin, what is natural is good. While Marx believed a transformation of the underlying modes of production (likely necessitating a "dictatorship of the proletariat" to bring it about) would result in our "consciousness" changing to reflect a newfound sense of justice, Bakunin considered our "natural" way of being, or our spontaneous impulses, to be inherently good and existing prior to and in spite of coercive modes of production that often distorted this underlying nature. No other laws but the "laws of our own nature" should limit us. In this way, Bakunin thought we were already free in so far as we could act according to our natures; Marx rejected this logic in favor of a more determinist account of our inclination towards freedom. In this way, Bakunin felt the "instinct of liberty" was lacking in Marx. ${ }^{208}$

Bakunin often returned to his critique of the "speculations" he thought integral to Marxian theory but was equally aware of the benefits of a "rationalistic" and "scientific" approach both to the study of society and the command and control of the natural world. While Marx and Bakunin were not adherents to any kind of a priori metaphysics

\footnotetext{
207 “The Philosophical Roots of the Marx-Bakunin Conflict," Ann Robertson, accessed March 31, 2016, https://www.marxists.org/reference/archive/bakunin/bio/robertson-ann.htm

${ }^{208}$ Bakunin quoted in "Marx-Bakunin Conflict."
} 
(associated with figures like figures like Descartes, Spinoza, and Leibniz) they both championed the utility of science and the notion of universal enlightenment.

Bakunin thought we could certainly have tools (e.g., our faculty of reason, science, and technology) to manipulate our environment and dominate it for the sake of our liberation, thereby echoing the mechanistic ideals of Francis Bacon and Sir Isaac Newton. ${ }^{209} \mathrm{He}$ also recognized that such tools, while indispensable to the rational organization of society, were incapable of concerning themselves with what is "real and living" and therefore contrary to the "real or practical organization of society." 210 That is, Bakunin distinguishes between the (what he thinks is a false) idea that only that which is measurable is real and therefore manipulable and the actual manipulation of things being concretely beneficial. One seems to be a purely philosophical controversy for Bakunin; the other seems to be a political or practical judgment.

Moreover, echoing his Romantic predecessors and contemporaries, Bakunin saw anarchism much like art, and he sees scientific efforts to discover principles of justice as contrary to the revolutionary ideals that guided him. ${ }^{211} \mathrm{He}$ notes, "Art, then, is as it were the return of abstraction to life; science on the contrary, is the perpetual immolation of life, fugitive, temporary, but real, on the altar of eternal abstractions." ${ }^{, 212}$ According to Bakunin, anarchism reflects our bodily rhythms, communal instincts, biological cycles,

\footnotetext{
${ }^{209}$ Thomas Martin, "New Remedies or New Evils? Anarchism and the Scientific Revolution" in New Perspectives of Anarchism, ed. Nathan J. Jun and Shane Wahl (Lanhan: Lexington Books, 2010), 364-386.

210 Bakunin, God and the State, 62.

${ }^{211}$ Interestingly, Marxist portrayals of anarchism as infantile and idealistic echoed the Victorian reception of Romanticism. See Jared McGeough, "Romanticism after the Anarchist Turn," Literature Compass, volume 13, number 1 (2016), 3-12.

${ }^{212}$ Ibid, 57.
} 
and natural inclinations. It reflects our nature and is in turn natural. While science seeks to manipulate, change, and renounce that nature. Bakunin insisted science sought to tame our creative urges and channel our natural inclinations in ostensibly productive ways. Such a "scientific" endeavor was, for Bakunin, anathema to anarchists.

Bakunin saw improvisation and emotion as central to the revolutionary endeavor. The constant resistance of anarchists to standardization and abstraction (especially when concerning revolutionary strategy) is part and parcel of the anarchist ideal. It is a sentiment echoed often by anarchists, most notably Emma Goldman, who famously insisted she did not want a revolution where she could not dance. ${ }^{213}$

Nevertheless, Bakunin's thinking on science and Reason oftentimes seems to contradict his steadfast opposition to intellectual absolutism. Bakunin has a complicated philosophical relationship with science. While he admonishes the authority of institutionalized science he recognizes the incredible technological advances only made possible by science. He also recognizes the liberty such advances facilitate. Many of Bakunin's writings on science, Reason, and intellectualism are attempts to reconcile the authority of science with his unshakable belief in liberty. He often does so by invoking the notion of progress (a quintessential Enlightenment ideal). He makes a distinction between revelation and investigation by noting that while the authority of the state and the church are based on either coercion or some unverifiable faith (often-times both), the authority of science lies in its ability to correct and continually perfect itself (reflecting in

${ }^{213}$ This maxim is attributed to Emma Goldman though she never actually wrote it. It is a common paraphrase of a passage in Living my Life where she reacts to being instructed to stop dancing at a party because it was unbecoming of a revolutionary and hurtful to "the cause." See Emma Goldman, Living My Life (New York: Knopf, 1934), 56. 
this way the anarchist ideals of reinvention and openness). He makes the distinction between revelation and investigation. While the authority of the state and the church is usually given, the authority of science is based on its ability to objectively verify its findings and investigate its own shortcomings all the while unceasingly furthering the human quest for truth and understanding.

For this reason, Bakunin notes, anarchists "recognize the absolute authority of science" but "reject the infallibility and universality of the savant." He continues,

In our church - if I may be permitted to use for a moment an expression which I so detest: Church and State are my two bête noires - in our church, as in the Protestant church, we have a chief, an invisible Christ, science; and, like the Protestants, more logical than even the Protestants, we will suffer neither pope, nor council, nor conclaves of infallible cardinals, nor bishops, nor even priests. Our Christ differs from the Protestant and Christian Christ in this - that the latter is a personal being, our impersonal; the Christian Christ, already completed in an eternal past, presents himself as a perfect being, while the completion and perfection of our Christ, science, are ever in the future: which is equivalent to saying that they will never be realized. Therefore, in recognizing absolute science as the only absolute authority, we in no way compromise our liberty. ${ }^{214}$

Moreover, while statist and religious paradigms often call for sacrifice in the name of patriotism or salvation, Bakunin thinks science does no such thing. Instead of our lives

${ }^{214}$ Bakunin, God and the State, 34. 
being imbued with meaning and purpose through our cultivation of national identity or religious piety with disastrous consequences for the expansion of our freedom, science helps lead us to our self-identified goals and thereby expands freedom by bringing us progressively closer to truth (truth being the natural consequence of freedom for Bakunin and many anarchists). Essentially, "In a word, science is the compass of life; but it is not life. ${ }^{215}$

Science cannot tame life nor can it grasp it in its entirety. The conceptual distinction to keep in mind here is Bakunin's differentiation between our natural life (rooted in spontaneity, instinct, and art) and the kind of artificial conceptual or scientific analysis that many times tries to impose itself on natural life. As mentioned earlier, Bakunin's "naturalism" reflects the ongoing disagreement with Marxists on a host of issues that unite anarchists against the perceived "absolutism" (both political and metaphysical) of Marxist philosophy. McLaughlin notes,

Indeed, this rejection of 'absolute' historical materialism, or of historical materialism as such (the theory - understood either as all-explaining, or in Popper's terms, unfalsifiable or irrefutable economic determinism... or as grand metaphysical construct - is absolutist by its very nature) unite anarchists from Bakunin and Kropotkin to Bookchin and Chomsky. ${ }^{216}$

It is, again, this tendency towards intellectualism, abstraction, and "metaphysics" usurps the spontaneity so central to Bakunin's anarchism.

\footnotetext{
${ }^{215}$ Ibid, 55.

${ }^{216}$ McLaughlin, 166.
} 
Moreover, and perhaps most forcefully, Bakunin identifies intellectualism and the worship of science with a worship of the state. He finds both supportive of hierarchy and arbitrary authority as well as equates the totalizing nature of one to be easily translated into and transferable to the other. Bakunin notes,

Idealists of every stripe, metaphysicians, positivists, defenders of the predominance of science over life, and doctrinaire revolutionaries - all of them with identical ardor through different arguments uphold the idea of the state and of state power. With perfect logic [sic] (in their own terms), they regard it as the sole salvation of society. I say with perfect logic [sic] because once they have adopted the position - utterly false, in our view - that thought precedes life, that abstract theory precedes social practice, and that sociology must therefore be the point of departure for social upheavals and reconstructions, they necessarily conclude that since thought, theory, and science, at least for the present, are the property of a very few individuals, those few must be the directors of social life. $^{217}$

According to Bakunin, so-called intellectuals tend to serve power precisely because they tend to think they should, themselves, occupy positions of power and because they are less likely to want to change a status quo that has elevated their social status. Moreover, Bakunin claims the more critical they may be in the world of ideas the less so is that critique translated into progressive social action. In a commentary on servility to power in mid-nineteenth century Prussia, Bakunin notes that

${ }^{217}$ Bakunin, God and the State, 136. 
...it is clear why the doctors of philosophy of the school of Hegel, despite their fiery revolutionism in the world of abstract ideas, in actuality turned out to be not revolutionaries in 1848 and 1849 but for the most part reactionaries, and why the majority of them today have become avowed supporters of Bismarck. ${ }^{218}$

Bakunin recognized the tendency of intellectual aristocratism to translate into political absolutism precisely because intellectuals either benefit from this absolutism or it pleases their elitist pretensions. Moreover, Bakunin simply viewed the enterprise of elitist intellectual debate as wholly divorced from fostering social change. He notes, "Even the most rational and profound science cannot divine the form social life will take in the future. It can determine only the negative conditions, which follow logically from a rigorous critique of existing society." ${ }^{219}$ In other words, we cannot map out exactly how a future society would look like, but only question and critique the existing one. This seems to draw a distinction between state planners and political activists like Bakunin and further encourage us to view Bakunin as an anti-intellectual as well as an antiauthoritarian thinker.

Intellectual aristocratism is central to the tendency towards government by scientists. Bakunin considers it an evil inherent to reformists and "social engineers" of all political persuasions. They all share an underlying faith in our ability to shape the desires of the people and channel these desires as well as their creative urges in politically expedient ways. Those who aspire to these feats of social engineering usually occupy

\footnotetext{
${ }^{218}$ Ibid, 138.

${ }^{219}$ Ibid, 198.
} 
important posts in ever more powerful states and these constitute, according to Bakunin, government by scientists. He parses this observation by noting that such a government by scientists is contrary to liberty while science itself is key to it. As Bakunin emphatically put it,

But until the masses have reached a certain level of education, will they not have to let themselves be governed by men of science? God forbid! It would be better for those masses to dispense with science altogether than to allow themselves to be governed by men of science. The first effect of the existence of such a government would be to render science inaccessible to the people. For such a government necessarily would be aristocratic, because existing scientific institutions are aristocratic by their essential nature. ${ }^{220}$

He means to say scientific institutions exclude the general population despite the need of the general population to utilize science for their own liberation. Moreover, such a general education cannot be reached when the ends of education are the furthering of institutionalized science (we see this at universities that tailor research to funding dollars instead of to human needs). Rather, education independent of the institutional logic of centers of education is what was necessary for Bakunin.

Moreover, Bakunin notes that the scientific, technocratic, educated, and otherwise "intellectual" class tends to further the interests of the bourgeoisie. He notes,

${ }^{220}$ Bakunin, The Political Philosophy of Bakunin, 78. 
In all European states it is only the bourgeoisie, an exploiting and dominating class - including the nobility, which today exists only in name - that receives a more or less serious education. Apart from that, a special minority is produced from the midst of the bourgeoisie, one which devotes itself exclusively to the study of the greater problems in philosophy, social science, and politics. It is this minority that, properly speaking, constitutes the newest aristocracy of the licensed and privileged 'intellectuals.' It is the quintessence and the scientific expression of the spirit and interests of the bourgeoisie. ${ }^{221}$

Indeed, advances in science as well as art and culture seem to mostly benefit a small privileged class according to Bakunin. Like Marx, Bakunin claims these advances also serve as instruments of domination and exploitation undeniably reflecting the culture and interests of the dominant class. Bakunin also realizes the growth of poverty among the masses is accompanied by the growth of technical progress under capitalism. While this "progress is stupendous," it is also true that "the more it grows, the more does it become the cause of intellectual and consequently material slavery, the cause of poverty and mental backwardness of the people; for it constantly deepens the gulf separating the intellectual level of the privileged classes from that of the great masses of the people."222

“How can workers break this vicious circle?" Bakunin asks. He answers,

They must, of course, acquire knowledge and take possession of science - this mighty weapon without which, it is true, they can make revolutions, but lacking

${ }^{221}$ Ibid, 82.

${ }^{222}$ Ibid. 
which they will never be able to erect upon the ruins of bourgeois privileges the equality of rights, justice, and liberty which constitute the true basis of all their political and social aspirations. ${ }^{223}$

The role of science as a tool for liberation is clear in Bakunin. Nevertheless, he also regrets that advances in the "administration of things," themselves reflective of scientific advances, were designed to oppress workers. ${ }^{224}$ The difficulty is then to take control of "science" in much the same way the proletariat should seize the means of production in Marxism. What is certain is that no "dictatorship" should follow from such a takeover according Bakunin.

This brand of anti-authoritarian anti-intellectualism draws a clear distinction between the concentration of scientific knowledge in institutions that tend towards authoritarianism and science itself. Bakunin made clear that "science is first of all based upon the co-ordination of a mass of personal experiences - past and contemporary always subjected to the rigorous test of reciprocal criticism. It is impossible to imagine any more democratic basis than this. ${ }^{, 225}$ Science serves as a common language across

\footnotetext{
${ }^{223}$ Ibid, 82-83.

${ }^{224}$ Leier quotes Bakunin, "The 'science of government, the science of administration, and financial science' was nothing more than the 'science of fleecing the people without making them complain too much and, when they begin to complain, the science of imposing silence, forbearance, and obedience on them by scientifically organized violence; the science of tricking and dividing the masses of people, of keeping them eternally and advantageously ignorant,' so they could never unite, and the science of the military, making it much more powerful 'and allowing it to be present, to act, and to strike everywhere."' See Leier, Bakunin: The Creative Passion, 243.

${ }^{225}$ Bakunin, The Political Philosophy of Bakunin, 69.
} 
space and time and between people of different cultures. ${ }^{226}$ It is for this reason that, according to Bakunin, the scientific method is essentially democratic and egalitarian.

This view of science reflects Bakunin's hope for the unity of humankind. While we are infinitely varied in our interests, tastes, and dispositions, we all share an underlying humanity that reflects Bakunin's view of science. In other words, Bakunin contrasts the democratic and egalitarian nature of science to the authoritarianism and privileged position of theology and metaphysics. He considered science could provide an epistemological unity without the pretension to abstraction. The results of scientific research aggregated bits of knowledge without an aspiration to universal, abstract (and ultimately, empty and meaningless) knowledge. He notes, "The great unity of science is concrete. It is unity in infinite diversity, whereas the unity of theology and metaphysics is abstract; it is a unity in the void."${ }^{, 227}$

To complicate matters a bit, while we are all unique (though essentially social creatures), and Bakunin thought we should embrace that diversity, he also thinks we share the underlying faculty of reason. While this does not contradict his celebration of human diversity it does call into question his commitment to difference in the face of totalizing metaphysical abstractions. Indeed, Bakunin complicates the neat distinction between science and its institutionalization as well as between science and metaphysical abstractions when he equates human reason as a unifying and identical faculty we all share and, moreover, identifies that unifying faculty with science itself. He undermines

\footnotetext{
${ }^{226}$ Ibid.

${ }^{227}$ Ibid, 72.
} 
the individuality he praises by highlighting our identical rationality and its relation to science. Bakunin notes

The world is a unity, notwithstanding the infinite variety of its component beings. Man's reason, which takes this world as an object to be recognized and comprehended, is the same or identical, despite the infinite number of various human beings - past and present - by whom it is represented. Science, therefore, also must be unified, for it is but the recognition and comprehension of the world by human reason., 228

He continues, "Metaphysics... acted according to the method of centralized states. Rational philosophy, on the contrary, is a purely democratic science.,"229

Despite claiming that we are naturally endowed with an identical faculty of reason he made no claim to our "natural" equality. The inequality bred of intellectualism is not a reflection of differences in our natural endowments but rather differences engendered by social injustice. Intellectualism is dangerous because it privileges certain members of society. When we create institutions and modes of society that create castes of "intellectuals" (e.g., a vanguard party or a privileged class of people that attend the most well funded and prestigious universities) we create inequality in every other sphere of society (including the economic and the political). That is why Bakunin was convinced that "the social environment, social position, and conditions of existence, are more powerful than the intelligence and will of the strongest and most energetic individual. It

\footnotetext{
${ }^{228}$ Ibid, 68.

${ }^{229}$ Ibid, 73.
} 
is precisely for this reason that we demand not natural but social equality of individuals as the condition for justice and the foundation of morality."230

Bakunin's general attitude toward intellectualism can be summarized in the following way. The distinction between the democratic and egalitarian nature of science and the authoritarian manifestations of its institutionalization and the contrast between science and the authoritarian pretensions of theology and metaphysics are at the heart of Bakunin's anti-intellectualism. While Bakunin equates scientific institutions with aristocracy, he equates science itself with egalitarianism. While he rejects the overarching ideal of Reason, he embraces our most esteemed faculty, reason. While he understands the limits of the scientific endeavor he also sees that same endeavor as the key to guiding our search for liberty. Indeed, Bakunin recognized the reductionist impulse of scientism as a danger. The usually self-glorifying notion of scientific progress represented an uncritical faith in the benign nature of technological and scientific advancements. Bakunin warned that technical and scientific experts might use their knowledge to dominate ordinary citizens and while Bakunin was critical of this potential domination he did not reject the validity of scientific knowledge. He only recognized that the tendency to reduce life to formulaic expressions and subsume it to technocratic control would likely lead to tyranny. ${ }^{231}$ This was at once a stance against the authoritarian tendencies of intellectuals and institutionalized science as well as a wariness of totalizing metaphysical notions like Reason itself.

\footnotetext{
${ }^{230}$ Bakunin quoted in Leier, 275.

${ }^{231}$ Avrich, Anarchist Portraits, 15.
} 
Indeed, there seem to be two competing tendencies in Bakunin's thoughts on science and intellectualism. On the one hand, his skepticism towards the concentration of scientific knowledge (in institutions as well as individuals) points to its pernicious effects in much the same way as concentrations of political or economic power would have pernicious effects. On the other hand, there is an unsullied hope in the unity of knowledge and the existence of such unity being decipherable through our faculty of reason, yet still somehow interwoven with the infinite contingencies of the human experience.

\section{Between Reason and Scientism: Peter Kropotkin and Free Inquiry}

The general thrust of Kropotkin's writings on anarchism includes not only a clear opposition to the state and capitalism but also highlights anarchism's underlying scientific basis. Kropotkin was the quintessential representative of "scientific anarchism." A scientist himself (he was a geographer), he based his anarchism on evidence of human cooperation as a survival strategy. Kropotkin's anarchism was based not on abstract principles but rather on these naturally occurring cooperative elements and tendencies of human life that undergird the processes of free association central to the anarchist tenets of liberty and equality. Nevertheless, while celebrating science as central to progress and to discovering the proper ordering of society, Kropotkin also recognized the limits of science and, more importantly, both the sometimes authoritarian excesses of its practitioners as well as the authoritarian institutional logic of scientific associations and universities. He also took aim at the specialization and division of labor that was a 
byproduct of scientific progress and hoped to further the idea of "integral education" that would combine both "intellectual" and "manual" labor.

According to Roger N. Baldwin, Kropotkin described anarchism "in relation to the tendencies away from metaphysics and towards physics. ${ }^{232}$ By this he meant that Kropotkin sought to shift the basis of anarchism from abstract ideals to notions rooted in empirical scientific evidence and understanding. According to Kropotkin, these naturally occurring elements and strategies of cooperation are only discoverable through the scientific method and empirical observation.

Through his observations, Kropotkin came to the conclusion that ....anarchism proves to be in accordance with the conclusions arrived at by the philosophy of evolution. By bringing to light the plasticity of organization, the philosophy of evolution has shown the admirable adaptability of organisms to their conditions of life, and the ensuing development of such faculties as render more complete both adaptations of the aggregates to their surroundings and those of each of the constituent parts of the aggregate to the needs of free cooperation. ${ }^{233}$

Kropotkin forcefully contrasts this view with a faith in the ideal of Reason. While he celebrated the scientific method he remained skeptical of overarching philosophical systems and the ungrounded faith in Reason on which they often depend. Many philosophical systems, such as Hegelianism for example, embraced the rational spirit or

\footnotetext{
${ }^{232}$ Peter Kropotkin, Anarchism, 145.

${ }^{233}$ Ibid, 53.
} 
the quasi-cosmic order of the universe; others, like Cartesian rationalism, relied on a thorough rational skepticism of the outside world and a celebration of the deductive method which cemented the mind/body divide and contributed to much subsequent philosophical scholarship and the idea that there exists a firm wall of separation between our mental and physical faculties.

Reacting to Hegelian idealism and the rationalism of scores of philosophical schools in his essay "Modern Science and Anarchism” Kropotkin notes

When the metaphysicians try to convince the naturalist that the mental and moral life of man develops in accordance with certain 'In-dwelling Laws of the Spirit,' the latter shrugs his shoulders and continues his physiological study of the phenomena of life, of intelligence, and of emotions and passions, with a view to showing that they can all be resolved into chemical and physical phenomena. He endeavors to discover the natural laws on which they are based. Similarly, when the anarchists are told, for instance, that every development consists of a thesis, an antithesis, and a synthesis; or that ' the object of law is the establishment of justice, which represents the realization of the highest idea;' or, again, when they are asked what, in their opinion, is 'the object of life?' they, too, simply shrug their shoulders and wonder how, at the present state of development of natural science, old-fashioned people can still be found who continue to believe in 
'words' like these and still express themselves in the language of primitive anthropomorphism... ${ }^{234}$

Moreover, for Kropotkin, just as important as a rejection of these philosophical systems was an appreciation of both mental and manual labor. Kropotkin would echo Bakunin's idea of integral education by describing anarchist communities where everyone would perform both "mental and manual labor."235

Kropotkin criticizes the division of labor and the intellectualism born of it. $\mathrm{He}$ laments the separation of the "brain worker" and the "manual worker" and the contempt among intellectuals and scientists of manual labor. Central to Kropotkin's notion of "integral education" is a blurring of the line between mental and manual labor as well as a celebration of the well-rounded individual. Kropotkin recognizes that knowing more and more about less and less is a feature of modern industry, science, and learning. While specialization may serve to advance science and industry it hinders the full development of individuals. Ostensibly, advances in science and industry should contribute to developing our human capacities in a free society, but under conditions of political and economic oppression they contribute to hindering human development.

Kropotkin sees the solution to this stagnation in combining scientific and, what he calls, handicraft education. He notes, "We maintain that in the interests of both science

${ }^{234}$ We should note that by "natural law" Kropotkin does not echo natural rights theorists like John Locke who argued our natural rights were reflective of our moral duty (that existed in the state of nature prior to the social contract). Rather, Kropotkin means to say that the social "laws" discovered by the scientific method regarding natural human behavior should be considered appropriate and he would regard anarchism to reflect these "natural laws." See Kropotkin, Anarchism, 151-152.

${ }^{235}$ Avrich, The Russian Anarchists, 95. 
and industry, as well as of society as a whole, every human being, without distinction of birth, ought to receive such in education as would enable him, or her, to combine a thorough knowledge of science with a thorough knowledge of handicraft. ${ }^{236}$ According to Kropotkin, employing our mental and bodily powers brings a sense of fullness and better prepares us for the work of the revolution and for revolutionary society.

Nevertheless, this belief in the importance of an integral education does not belittle the importance of science to discovering the tendencies in human relations and the proper ordering of society. Kropotkin is clear in his celebration of the scientific method. Indeed, anarchistic thinkers have taken him to task for it. Paul Feyerabend, for example, accuses Kropotkin of unquestioningly supporting the epistemological authority of science. He writes that Kropotkin, and anarchists generally, "swallow without protest all the severe standards which scientists and logicians impose upon research and upon any kind of knowledge-creating and knowledge changing activity."237

Feyerabend is largely correct about Kropotkin's celebration of science and logic. However, this does not mean that Kropotkin unquestioningly supports the idea that we should "swallow without protest" the standards of either. Kropotkin, like Bakunin, esteems individual and folk wisdom just as much as a strict scientific method and our faculty of reason. Moreover, Kropotkin contends the state and institutions like academia often marginalize unorthodox voices that might challenge the arbitrary epistemological

\footnotetext{
236 "Brain Work and Manual Work," Peter Kropotkin, accessed February 7, 2016, http://dwardmac.pitzer.edu/Anarchist_Archives/kropotkin/brainmanualwork.html.

${ }^{237}$ Paul Feyerabend, Against Method: Outline of an anarchistic theory of knowledge (London: Verso, 1975), 20.
} 
authority Feyerabend worried about. It is precisely the institutional manifestations of science (especially science supported by the state for reasons of state) that often exhibit an authoritarian impulse and reflects the class background of its practitioners.

Kropotkin does not see science itself (nor the underlying Reason it is said to reflect and manifest) as authoritarian despite the many authoritarian instantiations of reason and science in the same way we would not consider our sense of vision as inherently faulty in light of its many real-world imperfections (astigmatisms and the like). If we consider Reason as analogous to vision we can see that it would seem nonsensical to seek liberation from our sense of vision simply because of the many possible imperfections in those who see. Moreover, we can even claim that our personal experience and cultural background will affect how we "see" but it would be nonsensical to seek liberation from our vision for this reason. Indeed, Kropotkin would argue our capacity for reason (and the science that is bred of this human faculty) should not be denigrated because of the detrimental effects of certain instantiations of reason (and the institutions that have celebrated science and logic and cultivated a certain kind of knowledge).

We could parse this analogy a bit more and understand that Kropotkin views a certain kind of "vision" as authoritarian in the same way he considers a certain kind of exercise of science (and the institutional power and authority that accompanies it) as a threat to freedom. Indeed, we should think of it in the same way we think of "looking" and "seeing." While looking certainly describes vision in some sense it does not always entail an appreciation of dimensions, distances, or even accurate representations (we can 
think of how someone suffering from astigmatism of some kind does not really "see" what's in front of them but can certainly "look" at it). An appreciation of the "dimensions" of what is being "seen" is central to anarchist thought in the same way that a healthy skepticism of (or wearing corrective lenses to better "see") what is being "looked" at is generally a good thing if we suffer from astigmatism.

A dogged insistence that we should only "look" with our God-given eyesight in its purest form without corrective lenses or a consideration of what we are looking at and in what context we do so would be silly and unnecessarily dogmatic or conceptually "authoritarian" for anarchists like Kropotkin. Anarchists, including Kropotkin, have always been keen to appreciate context and particularities of given situations in this way. To continue the analogy, Kropotkin would insist that while there is only one way to "look" there are many ways to "see" and that anarchists can appreciate vision as well as anyone but they are also skeptical as to the idea of "looking" always entailing "seeing.,"238

It is the danger of insisting on only a certain kind of "looking" that Kropotkin sees as dangerous. Kropotkin rejects the dogmatism of a celebration of Reason or science while embracing our faculty of reason and the scientific method. Indeed, Kropotkin exemplified the spirit of rational inquiry while noting the dangers of a scientism that would reduce the study of humankind to totalizing onto-epistemological axioms. According to Brian Morris, Kropotkin, like Marx, "stood firmly in the tradition of the Enlightenment" in his "affirmation of reason." He stressed the importance of

\footnotetext{
${ }^{238}$ I am indebted to Dr. Bruce Hauptli for this analogy.
} 
...free inquiry and secularism; an advocacy of scientific materialism and the repudiation of mythology, mysticism, and religious dogma as modes of understanding the world; a respect for craftsmanship and an enthusiasm for industry, coupled with a belief in human progress through the application of science and technology; an emphasis on individual liberty and equality and the promotion of a cosmopolitan outlook; and finally, a repudiation not only of sacred texts but of the past, of the classical literature of antiquity, as a source of authority.

However, Kropotkin's worldview was not a simple scientism. According to Morris, Kropotkin thought the "identification of the Enlightenment with a blind faith in progress or with a naïve rationalism is facile in the extreme. ${ }^{, 239}$ Nor did Kropotkin reduce human existence or nature to a scientistic reductionism.

Kropotkin took care to remind us that individuals have varied natures. He recognized that we were capable of great altruism and cooperation as well as other desires that led us to egoism and the domination of others. ${ }^{240}$ Importantly, this conception of human nature resisted the axiomatic reductionism of other classical anarchist thinkers. Nevertheless, for Kropotkin, it is precisely this variation that necessitates an anarchist society of free association. In his The Conquest of Bread, Kropotkin notes,

And as all men do not and cannot resemble one another (the variety of tastes and needs is the chief guarantee of human progress) there will always be, and it is

\footnotetext{
${ }^{239}$ Brian Morris, Kropotkin: The Politics of Community (Amherst: Humanity Books, 2004), 130.

${ }^{240}$ Ibid, 77.
} 
desirable that there should always be, men and women whose desire will go beyond those of ordinary individuals in some particular direction. ${ }^{241}$

According to Morris,

He [Kropotin] shared with Marx a great debt to both the logic and content of the eighteenth-century French Enlightenment, but... he rejected entirely its metaphysics of nature. He thus repudiated the anthropocentrism and essentialism of Enlightenment thought...as well as its radical dualisms (humanity/nature, $\operatorname{mind} /$ body, individual/society) and its mechanistic world picture. ${ }^{242}$

In large measure, Kropotkin endeavored not to invent society or human relations anew but rather to base his idea of social organization on what he saw as present and obvious in existing relations. Kropotkin's anarchist communism extrapolated from a perceived nature of human relations. It was

...less a vision of a future utopia but rather an attempt to sustain and develop the kind of institutions based on sociality and free cooperation that already formed an essential part of all human societies, even the most tyrannical. It was to preserve and expand the precious 'kernel' of social customs without which no human or even animal society, could exist. ${ }^{243}$

\footnotetext{
${ }^{241}$ Peter Kropotkin, The Conquest of Bread, ed. Marshall Shatz (Cambridge: Cambridge University Press, 2007), 95.

${ }^{242}$ Morris, 173.

${ }^{243}$ Ibid, 76.
} 
Kropotkin emphasized that individuals have varied natures and the most successful human societies and endeavors have been those based on cooperation. From his celebration of medieval guilds to the fact that wolves and lions hunt in packs and bees and ants cooperate to build their hives and colonies, examples of mutual aid are plentiful. ${ }^{244}$

Kropotkin's anarchism is based on a thoroughly scientific worldview that rejects the metaphysical dualisms reminiscent of the Enlightenment and embraces humankind's varied nature and its identification with nature itself. Morris quotes Kropotkin,

Upon a mechanical explanation of all phenomena, embracing the whole of nature - that is, including in it the life of human societies and their economic, political and moral problems. Its method of investigation is that of the exact Natural Sciences, and, if it pretends to be scientific, every conclusion it comes to must be verified by the method by which every scientific conclusion must be verified. It aims to construct a synthetic philosophy comprehending in one generalization all the phenomena of nature - and therefore also the life of societies. ${ }^{245}$

Indeed, “Kropotkin, following the radical implications of Darwin's theory of evolution, therefore rejected any metaphysical dualism between humans (and their social life) and nature - for Kropotkin continually emphasized that humans are a part of nature."246

\footnotetext{
${ }^{244}$ See Peter Kropotkin, Mutual Aid: A Factor in Evolution (Forgotten Books, 2008[1902]).

${ }^{245}$ Ibid, 117.

${ }^{246}$ Ibid.
} 
As is made evident by the historical, sociological, and consequentialist reflection in Mutual $\mathrm{Aid}^{247}$ as well as his scientific outlook, Kropotkin sought not to marry himself to any one philosophical paradigm. Kropotkin's philosophy, most notably his philosophy of nature, seemed to be a via media between the idealism of those who postulate a "radical separation of humanity and nature" or deny "the reality of an external world (exemplified by neo-Kantian philosophy, hermeneutics, and postmodernism), and a reductive form of materialism." Kropotkin combined a humanism that emphasized "human agency and the recognition that human social life and culture constitute a relatively autonomous realm of being" and a naturalism that recognized humans as "an intrinsic part of nature. ${ }^{248}$

Revolution, for Kropotkin, entailed a transformation of society attuned to natural human relations absent the ossification of its institutional residues in the form of government. "The notion of a 'revolutionary government' Kropotkin considered to be a contradiction in terms, for 'revolution' and 'government' were incompatible concepts. 'The one is always the negation of the other,' he wrote, and apart from anarchy 'there can be no revolution." ${ }^{\prime 249}$ Likewise, for Kropotkin, law itself (perhaps the most omnipresent instantiation of state power) was antithetical to the both the basis of a free society and its natural state. "We need to recognize that the 'law' is a relatively modern phenomenon and that humans have lived for many centuries without any kind of written law. Since

\footnotetext{
${ }^{247}$ See Kropotkin, Mutual Aid

${ }^{248}$ Morris, 23.

${ }^{249}$ Ibid, 53.
} 
earliest times humans have regulated their lives through habits, local customs, and cultural usages." 250 Indeed, "Nothing good, he wrote, "is made except by the free initiative of the people, and all power tends to kill it.",251

In fact, for Kropotkin, it is precisely science that combats the totalizing ontoepistemological maxims and axioms of the nineteenth century metaphysicians that sought to root out "habits, local customs, and cultural usages." Kropotkin saw science as providing knowledge for solutions to specific problems while following a general method for attaining that knowledge. While the scientific method was standard, the problems tackled and experimental results could be applied to an infinite variety of localized contexts. This possibility is central to Kropotkin's anarchism and to the anarchist acknowledgement of our "need of knowledge, of brains and of the voluntary collaborations of a host of local and specialized forces which alone can attack the diversity of economic problems in their local aspects." 252

Kropotkin notes,

In anarchism there is no room for those pseudo-scientific laws with which the German metaphysicians of the first thirty years of the nineteenth century had to content themselves. Anarchism does not recognize any method other than the natural-scientific, and it applies this method to all the so-called humanitarian sciences. Availing itself of this method as well as of all researches which have

\footnotetext{
${ }^{250}$ Ibid, 77.

${ }^{251}$ Ibid, 53.

${ }^{252}$ Kropotkin, Anarchism, 256.
} 
recently been called forth by it, anarchism endeavors to reconstruct all the sciences dealing with man and to revise every current data of right and justice on the bases which have served for the revision of all natural sciences. Its object is to form a scientific concept of the universe embracing the whole of nature and including man. ${ }^{253}$

While this call may seem epistemologically and ontologically universalizing it is important to keep in mind what Kropotkin means by science. Science is a tool that, while embracing the study of nature (including human beings and society) as a whole, serves the interests of particularized solutions to specific problems as well. In Kropotkin's case, the overarching problem is a proper ordering of society that Kropotkin thinks should reflect both the history of human communities (themselves, historically, run along the lines of free association and mutual aid) and the behaviors of animals.

Nevertheless, Kropotkin also clearly outlines what he thinks are the limits of science in so far as it informs anarchism.

Anarchism like socialism in general, and like every other social movement, has not of course developed out of science or out of some philosophical school. The social sciences are still far removed from the time when they shall be as exact as are physics and chemistry...It would be unreasonable, therefore, to expect of the young social sciences, which are concerned with phenomena much more complex than winds and rain, that they should foretell social events with any approach to certainty. Besides, it must not be forgotten that men of science, too, are but

${ }^{253}$ Ibid, 192. 
human, and that most of them either belong by descent to the possessing classes and are steeped in the prejudices of their class, or else are in the actual service of government. Not out of universities therefore does anarchism come.

It remains important, according to Kropotkin, to recognize the limits of both science itself and those who practice science as well as to guard against the institutional logic (itself bred of authoritarian tendencies) of scientific associations and universities. He continues, "Like socialism in general, and like all other social movements, anarchism was born among the people; and it will continue to be full of life and creative power only as long as it remains a thing of the people. ${ }^{, 254}$

\section{Reconciling Anti-Intellectualism, Reason, and Science}

By seeing the social world and the physical world as just one natural world, Bakunin and Kropotkin saw science as reflective of our natural ability to reason and as the key to discovering the "natural laws" that would lead us to anarchism. They considered the anarchist endeavor intimately tied to scientific progress all the while noting the dangers of elevating science and our most esteemed faculty to the level of their most cherished ideal: liberty. ${ }^{255}$ Instead, anarchists like Bakunin insisted, "Once more, Life, not science, creates life; the spontaneous action of the people themselves alone can create liberty." 256

\footnotetext{
${ }^{254}$ Ibid, 146.

${ }^{255}$ Bakunin, God and the State, 34.

${ }^{256}$ Ibid, 63-4.
} 
Bakunin and Kropotkin recognized Enlightenment values as channeling both liberating and pernicious tendencies. While both thinkers celebrated the discovery of truth through science and the exercise of reason they were also quick to point out that excessive abstraction, institutionalization, and compartmentalization of rationality and science led to concentrations of power and authority that are unacceptable to anarchists. The predictable consequences of the worship of Reason and science, which take the shape of an intelligentsia subservient to power, the excessive separation of intellectual from manual labor, and the idolization of Reason and science, contribute to the intellectualism Bakunin and Kropotkin consistently combatted.

In both Bakunin and Kropotkin we see a clear distinction between a disdain for the intelligentsia and an appreciation of reason and science. While scientism and a worshipping of Reason were products of the intelligentsia and the institutions that afforded and perpetuated their power, a clear appreciation for Enlightenment values unvarnished by the class oppression of state and capitalist systems imbued most anarchist thought. By keeping in mind this qualified support of the ideal of Reason we see a clear appreciation for science as a liberating force (so long as it is divorced from its authoritarian ties to the state and capitalism).

By rejecting dogmatism in every realm (including the intellectual) both Bakunin and Kropotkin highlighted the anti-authoritarian elements of diversity, localism, and pluralism in matters of philosophy and science. They both share a steadfast opposition to univocal expressions of truth, Reason, and science as well as a healthy suspicion of the institutional manifestations of them all. They agree there are many ways to tackle 
important social issues and matters of justice yet diagnosed a persistent intellectual monomania in the problematizing and resolving of these same issues. 


\section{Chapter 4}

\section{Anti-Authoritarianism as Anti-Intellectualism:}

\section{Stirner, Nietzsche, and the Anarchic Politics of Postfoundationalism}

"Caminante no hay camino se hace camino al andar." - Antonio Machado ${ }^{257}$

This chapter will examine Max Stirner's and Friedrich Nietzsche's challenges to traditional Western metaphysics and epistemology and their connection to antiauthoritarian thought (especially the anarchist tradition and recent developments in postfoundational anarchist theory). My purpose is to stress the importance of both Stirner and Nietzsche in thinking about an anti-authoritarianism of the intellect (i.e., an antiauthoritarianism aimed at the epistemic authority of Reason, the scientific method, and other authoritative accounts of knowledge, as well as against the ontological categories usually used to sustain them). Conceiving of such an anti-authoritarianism of the intellect facilitates new ways of thinking about important political notions in the postfoundationalist context (e.g., domination) and relating them to traditionally nonpolitical notions (e.g., intellectualism).

I will consider how the anti-authoritarianism of these thinkers questions the legitimacy of not only politics and political institutions but also apolitical hierarchies that nevertheless govern our thinking. This anti-authoritarianism of the intellect rejects what William James called "intellectualism" or the grafting of conceptual frameworks onto our

\footnotetext{
${ }^{257}$ Wanderer there is no path, wandering makes the way [my translation]. "Caminante no hay Camino," Antonio Machado, accessed 6/29/2016, http://gwenglish.blogspot.com/2014/04/poem-of-day-antoniomachados-caminante.html.
} 
understanding of the world and the lauding of such grafting as exact, thorough, and scientific. $^{258}$

While the history of critical political thought is rife with anti-authoritarian discourse aimed at political, economic, and cultural domination, postfoundational anarchist discourse takes inspiration not only from radical anti-capitalist and anti-statist frameworks of analysis but also anti-metaphysical thinkers like Stirner and Nietzsche. Stirner and Nietzsche highlighted our dubious romance univocal understandings of Reason, essentialist views of human nature, and other kinds of onto-epistemological foundationalism. Their interrogation of foundationalism illustrated anarchist antiintellectualism.

Intellectualism in the anarchist tradition is nuanced and defies easy categorization. While other radical traditions like Marxism openly espouse their scientific and rationalistic aspirations (e.g., a theory of scientific socialism and a dialectically materialist understanding of history) and other quintessentially modern political traditions like liberalism easily betray their foundational assumptions (e.g., atomized individuality, rational self interest), anarchism does not lend itself to a static philosophical reading. While these scientific aspirations and foundational assumptions frame Marxism's and Liberalism's endeavor to secure liberty and equality they also seem to unwittingly reinforce a certain kind of domination, hierarchy, or arbitrary authority.

Historically, the calling of anarchism has been to oppose domination, hierarchy, and arbitrary authority wherever it may be present. These sorts of dominion have been

\footnotetext{
${ }^{258}$ William James, A Pluralistic Universe [iBook], lecture 6 "Bergson and His Critique of Intellectualism."
} 
readily challenged in the realms of state power, the concentration of wealth, the spiritual authority of the Church, and patriarchy while it has been little explored in the "struggle over signs, symbols, representations, and meaning in...everyday life."259

Postfoundational anarchism seeks to fill such a gap in anarchist anti-authoritarianism. ${ }^{260}$ In order to do so these contemporary anarchists appropriate postfoundationalist discourses to better apply such anti-authoritarian critiques to the realms of ontology and epistemology. Such a broadening of how we think about domination, hierarchy, or authority in the postfoundationalist context is crucial to understanding these contemporary currents of anarchist theory and their precursors in anti-metaphysical nineteenth century thought.

Here, I will address Stirner's rejection of the ostensibly emancipatory value of language, essentialism, and rationality while noting his views on self-legislation and autonomy. I will also focus on Nietzsche's challenge to the authority of Reason in his analysis of the creative forces of the Dionysian, his rejection of transcendental moral absolutes, and his perspectivism. I will interrogate both Stirner's and Nietzsche's role in conceptualizing the beginnings of a postfoundational anarchism as well as their role in

\footnotetext{
${ }^{259}$ Jesse Cohn, "What's Wrong With Postanarchism?, accessed 02/19/2015, $\mathrm{http}$ //theanarchistlibrary.org/library/jesse-cohn-and-shawn-wilbur-what-s-wrong-with-postanarchism.

${ }^{260}$ Despite the appropriate postfoundational critique of some canonical anarchist thinkers like Proudhon and Godwin, other "classical anarchists" do not lend themselves as easily to accusations of essentialism, representationalism, and foundationalism. Mikhail Bakunin in his Statism and Anarchy makes clear his suspicion of "metaphysics" and "scientism." See especially page 133 in ed. Marshall Shatz (Cambridge: Cambridge University Press, 2005). Peter Kropotkin also took care not to marry himself to any one philosophical outlook (most notably any kind of scientism or reductionism). See especially his Mutual Aid: A Factor in Evolution (Forgotten Books, 2008[1902]). Nevertheless nearly all anarchist thinkers can be interpreted as having some kind of postfoundationalist inklings. For a concise response to the postfoundationalist critique of the anarchist "canon" see Jesse Cohn and Shawn Wilbur, "What's wrong with postanarchism?"
} 
sustaining and continuing the anti-intellectualist strain of anarchist thought. This will be, in part, an engagement with issues in the anti-intellectualism of these two thinkers and a reflection on their connection to the anarchist tradition (especially concerning the "anarchist turn" of late). ${ }^{261}$ While anti-intellectualism of this kind is not unique to Stirner and Nietzsche, ${ }^{262}$ they did serve as a clear bridge to contemporary anarchist antimetaphysical and, I argue, anti-intellectualist thought.

\section{Anti-Intellectualism}

By embracing these political features of seemingly apolitical onto-epistemological frameworks of understanding we consider an understanding of anti-intellectualism as an anti-authoritarianism that is key to the evolution of postfoundationalist anarchist thought. My aim is to frame an understanding of contemporary postfoundationalist anarchist antiintellectualism as grounded in these two thinkers and I hope to make evident the connection between this kind of anti-authoritarianism and the anarchist tradition.

As mentioned above, many consider the postfoundationalist tradition as the first sincere attempt to elude the hold of Reason on philosophy and what prominent social

\footnotetext{
${ }^{261}$ See Jacob Blumenfeld, Chiara Bottici, Simon Crtitchley, ed. The Anarchist Turn (London: Pluto Press, 2013).

${ }^{262}$ Nathan Jun highlights the fact that within the anarchist tradition, P.J. Proudhon's, Mikhail Bakunin's, and Peter Kropotkin's work served as precursors to skepticism towards epistemic authority and ontological absolutism. According to Jun, the so-called classical anarchists engaged in a critique of not only the traditional sources of political and economic power but also of political modernity itself. That is, they engaged in a critique of the ontological and epistemological categories that sustain the former. In other words, "...the anarchists of the nineteenth and twentieth centuries distinguished themselves by calling into question the entire conceptual framework of modernity - not just in its political dimensions, but in its philosophical, scientific, moral, cultural, and religious dimensions as well." That is to say, "anarchism is not a movement against authority, or not just that, but rather a movement against representationalism." See Nathan Jun, Anarchism and Political Modernity (New York: Continuum, 2012) 107.
} 
theorists have considered the "rationalization" of society. Reflections on the "iron cage" of modernity, the nihilism fueled by all-consuming rationalistic culture, the "disenchantment" of the Western world and the rise of instrumental rationality all contributed to a steady critique of the dangers of modern industrial and technological society. The move towards mastering "all things by calculation" 263 impelled social critics of all stripes to condemn the de-humanizing and dangerous tendencies of Fordist industrialism, politico-administrative instrumentalism, and the tragic expressions of rationality in twentieth century totalitarianism. This critique culminates in the Critical Theory of Max Horkheimer and Theodor Adorno that lambasted the liberating veneer of the Enlightenment ethos - namely, the idea that harnessing the power of reason to master both nature and ourselves led inevitably to freedom from the intellectual shackles secured by myths of all kinds (religious, political, cultural, etc.). ${ }^{264}$

However, these understandings of reason and rationality are distinct from those present in so-called classical anarchists like Godwin, Proudhon, Bakunin, and Kropotkin (and the anarchist tradition generally). While the former seems to center on an endeavor to command and control - an effort to instrumentally exploit the faculty of reason for the sake of an imagined progress, order, and efficiency - the latter seems strictly a satisfaction of the perennial philosophical and psychological need for certainty and even enjoyment in endeavoring towards an ideal that promised liberty and equality.

\footnotetext{
${ }^{263}$ See Max Weber, The Essential Weber, ed. Sam Whimster (New York: Routledge, 2004).

${ }^{264}$ See Max Horkheimer and Theodor W. Adorno, Dialectic of the Enlightenment: Philosophical Fragments, ed. Gunzelin Schmid Noerr, trans. Edmund Jephcott (Palo Alto: Stanford University Press, 2002).
} 
This difference is crucial to understanding why the classical anarchist tradition (itself derivative of Enlightenment ideals) does not laud the "rationalization" of societythat is, the instrumental logic that pervades social relations and administration and is usually accompanied by a callous disregard for the originally emancipatory quality of Enlightenment ideals - and the disjunction between anarchist and postfoundational anarchist thought. While critics like Weber, Adorno, and Habermas lambasted the rationalization of society, postfoundational anarchist critics attempt to escape the conceptual clutches of both rationalization and the ostensibly limiting discourse of the Enlightenment tradition while staying true to the intellectual spirit of classical anarchist anti-authoritarianism.

In other words, we should recognize a difference between this rationalization being dangerous because it moves away from Enlightenment ideals and those very same Enlightenment ideals being dangerous. According to Weber ${ }^{265}$ Horkheimer and Adorno, ${ }^{266}$ and Habermas, ${ }^{267}$ Enlightenment ideals are perverted by this rationalization while postfoundationalist critics recognize danger in these very ideals. It is the conception of Reason (the capital $\mathrm{R}$ denoting reason understood both as a faculty and an

\footnotetext{
${ }^{265}$ In "Science as a Vocation" Max Weber famously describes the "disenchantment" that accompanies modern "intellectualism" and "rationalism." He describes the overly zealous attachment to scientific explanation and recognizes its epistemic hubris as a symptom of such disenchantment. According to Weber, all science already presupposes some value judgment and to think otherwise is foolish. He notes that science already presumes certain things are "worth knowing" and intimates our presumably detached endeavor to "control everything by means of calculation" as misguided. See his Max Weber, ed. David Owen and Tracy B. Strong, trans. Rodney Livingstone, The Vocation Lectures (Cambridge: Hackett, 2004) See also Weber, The Essential Weber.

${ }^{266}$ In Dialectic of the Enlightenment, Horkheimer and Adorno describe how the Enlightenment ideal of Reason was perverted and employed to perpetrate the greatest crimes of the twentieth century and institute new modes of domination.

${ }^{267}$ See Jürgen Habermas, trans. J.J. Shapiro, Toward a Rational Society (Boston, Beacon, 1970) for an account of the rationalization and technocratization of the public sphere and politics.
} 
ideal) that accords with the latter which sustains much of the classical anarchist tradition as well as informs the kind of intellectualism to which Stirner, Nietzsche, and their postfoundationalist interlocutors react.

It is the latter conception that I argue is understood as a dominating force that serves as the critical object of anti-intellectualism and which sustains the critical ground of a politicized sense of onto-epistemological domination. Postfoundational anarchists seek to fulfill the promise of anarchism by applying anarchist anti-authoritarianism to ontology and epistemology. This is an attack on not only the "rationalization" already identified by Weber and others but also the support, albeit qualified, for Enlightenment ideals evidenced in the so-called classical anarchist tradition (or at least present in some of its figureheads: Godwin, Proudhon, Bakunin, Kropotkin, et al.). While these figureheads all had complex and occasionally contradictory approaches to intellectualism, Bakunin and Kropotkin were most outspoken on the issue. Bakunin was a thorough antiintellectualist and critic of what he called "metaphysics" and "scientism" 268 while Kropotkin accepted human nature as varied while committed to scientific free inquiry. ${ }^{269}$

\footnotetext{
${ }^{268}$ Bakunin notes "By 'metaphysicians' we mean not just the followers of Hegel's doctrines...but also positivists and in general all the present-day worshippers of the goddess science; all those who by one means or another (if only by a very diligent but necessarily always imperfect study of the past and present) have created for themselves an ideal social organization into which, like new Procrustes, they want to force the life of future generations whatever the cost; in short, all those who, instead of regarding thought or science as one of the necessary manifestations of natural and social life, take such a narrow view of that poor life that they see in it only the practical manifestation of their own thought and their own always imperfect science." See, Mikhail Bakinin, Statism and Anarchy, ed. Marshall Shatz (Cambridge: Cambridge University Press, 2005), 133.

${ }^{269}$ While Kropotkin accepted our varied natures and did not accept an essentialist view of ontological categories, he did recognize the efficacy of the scientific method. He concluded, "....every conclusion it [mechanistic explanation] comes to must be verified by the method by which every scientific conclusion must be verified. It aims to construct a synthetic philosophy comprehending in one generalization all the phenomena of nature - and therefore also the life of societies." See, Peter Kropotkin, The Conquest of Bread, ed. Marshall Shatz (Cambridge: Cambridge University Press, 2007), 95. For Kropotkin's rejection
} 
Godwin, on the other hand was, occasionally, an unapologetic rationalist, ${ }^{270}$ while Proudhon was a qualified essentialist and rationalist. ${ }^{271}$ Despite the variety in thought on the issue of Enlightenment ideals they all, in one form or another, embraced the intellectual spirit it fostered and endorsed the purportedly liberating effects of its zeitgeist. Nietzsche and Stirner on the other hand vociferously opposed Enlightenment ideals themselves and their purportedly liberating effects. It is the latter opposition that I think more directly addresses the anti-intellectualistic aspirations of postfoundational anarchy.

\section{Anti-Intellectualism and Postfoundationalism}

As already discussed, postfoundationalist anarchism is premised on recognizing the inherent authoritarianism in giving primacy to Reason and auxiliary concepts like human nature, "essentialisms" of all kinds, and binaries in the classical anarchist tradition

of metaphysical essentialism and what postfoundationalists would classify as totalizing notions, see his Mutual Aid: A Factor in Evolution (Forgotten Books, 2008[1902]).

\footnotetext{
${ }^{270}$ According to Godwin, equality itself was based on the existence of some independent Truth and an idealized Reason. Godwin notes, "There is no satisfactory criterion marking out any man, or set of men, to preside over the rest...all men are partakers of the common faculty, reason; and may be supposed to have some communication with the common instructor, truth." See, Enquiry Concerning Political Justice and its Influence on Modern Morals and Happiness (Harmondsworth, Middlesex, England: Penguin Books, 1976 [1798]) 231. Indeed, Political Justice addresses the idea of private judgment and Reason at length. Though he acknowledges the absurdity of a "one size fits all" view of legality and other authoritative vehicles of social control he does recognize the authority of natural law based on the dictates of Reason.

${ }^{271}$ While Proudhon is well known for noting the inherent complexity of life and our inability to perfectly graft any idealization onto it, he also had a quite reverent attitude towards Reason and towards the liberating effects of what later thinkers would call the "rationalization" of society. Proudhon notes, "Every question of domestic politics must be decided by departmental statistics; every question of foreign politics in an affair of international statistics. The science of government rightly belongs to one of the sections of the Academy of Sciences, whose permanent secretary is necessarily prime minister; and since every citizen may address a memoir to the Academy, every citizen is a legislator. But as the opinion of no one is of any value until its truth has been proven, no one can put his will in the place of reason-no one is king." See Proudhon, What is Property? Donald R. Kelly, Bonnie G. Smith, ed. (Cambridge: Cambridge University Press, 1994), 209.
} 
that may restrict meaning, understanding, and anarchist practice. The postfoundationalist anarchist recognition of authoritarianism in ontology and epistemology, especially the primacy given to Reason as an emancipatory tool and ideal in the anarchist tradition, echoes nineteenth century critiques of modernity. From Romanticism's attack on order and rationalism to American Transcendentalism's admonishment of intellectualism and empiricism, there has been no lack of criticism of the rationalistic, instrumentalist, and nihilistic tendencies of modernity. However, recent critiques of the Enlightenment and its discontents stress the incompatibility between freedom and the stifling effects of rationalistic discourse.

More recently, we have seen the debate over the authority of essentialist and universal accounts of ontological and epistemological categories that accompany such rationalism intensify in many philosophical traditions. American pragmatism and Latin American philosophy of liberation have both sought to counter supposedly Euro-centric tendencies ${ }^{272}$ in epistemology and ontology while others admit to the arbitrary nature of scientific principles and the mutually supportive naturalism that sustains it. ${ }^{273}$ This selfreferential nature exposes the lack of any undergirding philosophical foundation and reflects the concerns of postfoundationalist thought of the Continental tradition which has consistently challenged the essentialism and universalism of persistent philosophical dualisms (e.g., mind/body, true/false, good/evil) and rejected the underlying humanist

\footnotetext{
272 "Eurocentric" refers to those points of view that laud univocal accounts of human nature, objectivity, and European exceptionalism in matters concerning philosophy and theories of knowledge.

${ }^{273}$ See W.V.O Quine, "Epistemology Naturalized" in Ontological Relativity and Other Essays (New York: Columbia University Press, 1969), 69-90.
} 
philosophical presuppositions (e.g., essentialist view of human nature, belief in progress) which underlie, in their view, its veneer of pluralism, a supposedly liberating humanism, and a seemingly baseless meliorism.

Post-analytic philosophy has likewise stressed the unviability of traditional philosophical themes centered on these univocal concerns in ontology and epistemology and stressed the role of meaning, language, ethical direction and the practical pursuits of philosophical reflection ${ }^{274}$ while some recent philosophers of science have questioned the validity of claims to scientific knowledge given the supposedly authoritarian or fallacious tendencies of scientific discourse. ${ }^{275}$ Most contemporary musings on these challenges to rationalism first highlighted in the nineteenth century echo the common concerns of postfoundational thinking and harken back to the anti-foundationalist, anti-authoritarian and anti-intellectual thought of Stirner and Nietzsche.

Despite the long tradition of counter-Enlightenment thought, teasing out what is authoritarian or limiting about the privileging of Reason, or the primacy of ancillary notions like a well-defined human nature, can be difficult. The reasons for this difficulty are twofold. On the one hand, many prominent anti-authoritarian thinkers are accused of employing the ideal and privileging the faculty that is said to be authoritarian, namely,

\footnotetext{
${ }^{274}$ See John Rajchman and Cornel West, ed. Post-Analytic Philosophy (New York: Columbia University Press, 1985).

${ }^{275}$ The idea that rationality does not always fit the history or evolution of "science" is a prominent theme among some philosophers of science. Others seek to historicize science and the scientific method and thereby question its claims to timeless veracity. For a general understanding of the debate surrounding these issues see Thomas Kuhn, The Structure of Scientific Revolutions (Chicago: University of Chicago Press [1962] 1996), Imre Lakatos, Alan Musgrave, ed., Criticism and the Growth of Knowledge. (Cambridge: Cambridge University Press, 1970), Karl Popper, The Logic of Scientific Discovery (New York: Routledge, 1992), Paul Feyerabend, Against Method: Outline of an Anarchistic Theory of Knowledge (London: Verso, 1978), Feyerabend, Farewell to Reason (London: Verso, 1987).
} 
Reason. ${ }^{276}$ On the other hand, detecting the authoritarianism inherent in exercises of what one noted classical anarchist called private judgment could seem nonsensical, counterproductive and ineffable. ${ }^{277}$ After all, how else are we to combat the arbitrary authority of certain social and political institutions if not through our own reasoned and unimpeded judgment?

Nevertheless, we can diagnose unease with the authority of Reason by questioning the "intellectualism" inherent in modern thinking. We could acknowledge our tendency to claim our conclusions

....are the only logical ones, that they are necessities of universal reason, they being all the while, at bottom, accidents more or less of personal vision which had far better be avowed a such; for one man's vision may be much more valuable than another's, and our visions are usually not only our most interesting but our most respectable contributions to the world in which we play our part. ${ }^{278}$

Here, American pragmatist William James echoed Nietzsche's "perspectivism" yet recognized the necessity of a "stable scheme of concepts, stably related to each other" which "lay hold of our experiences" and "co-ordinate them withal." However,

\footnotetext{
${ }^{276}$ The most commonly cited argument in this vein is Jürgen Habermas' idea of performative contradiction, best outlined in Jürgen Habermas Moral Consciousness and Communicative Action, trans. C. Lenhardt and S.W. Nicholsen (Cambridge, Mass.: MIT Press, 1990).

${ }^{277}$ William Godwin famously lauded the importance of private judgment in affairs both public and private. See William Godwin, Enquiry Concerning Political Justice and its Influence on Modern Morals and Happiness (Harmondsworth: Penguin Books, [1798] 1976).

278 William James, A Pluralistic Universe [iBook], lecture 6 "Bergson and His Critique of Intellectualism."
} 
...all these abstract concepts are but as flowers gathered, they are only moments dipped out from the stream of mine, snap-shots taken, as by a kinetoscopic camera, at a life that in its original coming is continuous. Useful as they are as samples of the garden, or to re-enter the stream with, or to insert in our revolving lantern, they have no value but these practical values. You cannot explain by them what makes any single phenomenon be or go - you merely dot out the path of appearances which it traverses. For you cannot make continuous being out of discontinuities. The stages into which you analyze a change are states, the change itself goes on between them. It lies along their intervals, inhabits what your definition fails to gather up, and thus eludes conceptual explanation altogether."279

The ambition to map out the world (conceiving of it wholly and deciphering conceptual distinctions within it) is what James means by intellectualism. Indeed, this kind of "Thought deals thus solely with surfaces. It can name the thickness of reality, but it cannot fathom it, and its insufficiency here is essential and permanent, not temporary.”280

The authority of Reason and auxiliary notions is intimately related to our ambition to conceive of our world in its totality. Such folly, according to thinkers like Stirner, Nietzsche, and James, is responsible for our hubristic pursuit of celebrated ideals like liberty and equality. While such ideals may spark efforts at social progress and political emancipation (themselves equally idealized pursuits) and, often, secure concrete

\footnotetext{
${ }^{279}$ Ibid.

${ }^{280}$ Ibid.
} 
advances in combatting the domination of some over others, they often impede our efforts at thinking freely. Such efforts seem to rely on a limiting understanding of freedom that privileges intellectualist frameworks.

Martin Heidegger interprets this concern as a concern over thinking itself. While anarchism traditionally aims at dismantling sites of hierarchy and arbitrary authority without replacing them with new structures of domination, Heidegger also notes thinking itself does not aim at structuring new frameworks of understanding nor does it serve practical aims. By posing the question "what is called thinking?" Heidegger exposes what thinking is not. He notes, "1) Thinking does not bring knowledge as do the sciences. 2) Thinking does not produce usable practical wisdom. 3) Thinking solves no cosmic riddles. 4) Thinking does not endow us directly with the power to act."281

Leslie Paul Thiele reckons, what then is left for thinking? ${ }^{282}$ The answer to the question lies in not answering at all and instead challenging our most fundamental assumptions. We should, in the vein of Stirner and Nietzsche, seek to challenge the symptoms of the intellectualism James identified.

Key to challenging the authority of Reason as an ideal and a faculty is to understand a glorifying of Reason as a symptom of this intellectualism. I will not be conflating Reason and intellectualism but rather seeing a lauding of Reason (as both a means to emancipation and the result of emancipation in the anarchist sense) as

\footnotetext{
${ }^{281}$ Martin Heiddeger, trans. J. Glenn Gray, What is Called Thinking? (New York: Harper Collings, 2004), 159.

${ }^{282}$ Leslie Paul Thiele, Timely Meditations: Martin Heidegger and Postmodern Politics (Princeton: Princeton University Press, 1995), 95.
} 
undeniably "intellectual" in the Jamesian sense and worthy of anarchist anti-authoritarian critique in the postfoundationalist vein.

As mentioned above, despite countless attempts to challenge the hegemony of "intellectualism," there are two critiques that inspire the postanarchist tradition in explicit and obvious ways. Interlocutors of Nietzsche and Stirner have emphasized their contribution to postfoundationalist, anti-authoritarian and pluralistic ways of knowing and being that highlight both the supposed incoherence and the futility of an overreliance on Reason and auxiliary notions. ${ }^{283}$ While Nietzsche challenged the reliance on the Apollonian (i.e., the orderly, rational, and disciplined aspects of human thought and action), rejected transcendental moral absolutes, and emphasized interpretation and perspective in all questions of knowing, Stirner highlighted the arbitrariness of "fixed ideas," the limits of language in expressing ideas and inspiring action, and the stifling nature of conceptual frameworks of understanding. I argue that both Stirner and Nietzsche serve as linchpins and transitional figures in unpacking both what is antiintellectual about anarchism and what is anarchistic about anti-intellectualism and how related understandings of anti-authoritarianism inform a politicized sense of ontoepistemological domination.

\footnotetext{
${ }^{283}$ While many anarchists have garnered inspiration from both Stirner and Nietzsche, Emma Goldman and Saul Newman stand out as their most influential interlocutors in the tradition. While Emma Goldman lectured extensively on Nietzsche's thought and its value to anarchic anti-authoritarianism, Newman has argued Stirner to be the critical linchpin to non-essentialist anarchic critiques of liberal capitalist society. While Goldman's Nietzsche lectures were lost thanks to police raids on Mother Earth's headquarters she did write about Nietzsche's influence on her in Living my Life (New York: Dover, 1970). For a detailed consideration of Nietzsche's influence on the anarchist tradition see Moore, John and Spencer Sunshine eds. I Am Not A Man, I Am Dynamite! Friedrich Nietzsche and the Anarchist Tradition (New York: Autonomedia, 2004). For a detailed study of Stirner's relation to the anarchist tradition see Saul Newman (ed.) Max Stirner (London: Palgrave Macmillan, 2011).
} 


\section{Max Stirner, Anti-Authoritarianism and Anti-Intellectualism}

Max Stirner is best known as one of Karl Marx's “idealist” intellectual nemeses in The German Ideology. ${ }^{284} \mathrm{He}$ is also considered a prominent critic of the left-Hegelianism of his time and an inspiration for the individualist or egoist anarchist tradition. ${ }^{285}$ In the introduction to the Cambridge edition of Stirner's The Ego and its Own, David Leopold notes that "Since individual autonomy is incompatible with, and more important than, a general duty to obey the law, Stirner rejects absolutely the legitimacy of political obligation." 286 This view has of course secured Stirner as an important figure in the history of anarchist thought. However, Stirner's contribution to the anarchist tradition goes beyond a simple rejection of any raison d'état. Stirner interrogates the foundational onto-epistemological assumptions on which even the minimalist state seeks to pin its legitimacy. Moreover, Stirner goes beyond the state to interrogate the legitimating or foundational assumptions that govern any raison d'être.

For Stirner, overcoming these foundational assumptions begins with challenging understandings of selfhood, individuality, and autonomy. While the Enlightenment tradition gave us a robust account of social and political obligation tied to strong conceptions of human nature and its relation to the state, Stirner seeks to undo the

\footnotetext{
${ }^{284}$ Karl Marx dedicates several sections of The German Ideology (USA: Prometheus Books, 1998) to attacking Stirner's supposedly empty and idealistic notions of the ego and his politically sterile ideology more generally.

${ }^{285}$ Egoist anarchism had its adherents in European individualist strains of anarchism but was most prominent on the American scene. Benjamin Tucker exemplifies this movement in the U.S. For a general history of egoist anarchism (and anarchism generally), see Peter Marshall, Demanding the Impossible: A History of Anarchism (Oakland, CA: PM Press, 2010).

${ }^{286}$ Max Stirner, The Ego and its Own, ed. David Leopold (Cambridge: Cambridge University Press, 1995), xxvi.
} 
Enlightenment-inspired anthropocentric fabric of social contract theory while preserving the boundless pluralism only recognized through a thorough embrace of absolute individuality and autonomy. By rejecting the full spectrum of what he sees as religious thinking, as a way to embrace what contemporary postfoundationalist thinkers would call a de-totalized philosophical outlook, he embarks on a thorough critique of the history of philosophy.

He began this endeavor by appraising

...each of the dissident movements of the time - liberal humanism, philosophical realism, and the philosophy of pure criticism - and had found each of them infected by an ultimate compromise... at the last moment they had admitted to the presence of some transcendent object in the scheme of things - not indeed a 'God' in the sense of a personal deity, but a 'Humanity' or a 'Society' or a 'Morality', all of which were as fictitious, and as autocratic in their claims upon the individual concrete human being, as any personal God had ever been; and thus the project of atheism still had to be carried out to its conclusion."287

This theme of "total atheism" - that is, the complete rejection of any absolute authority, meaning or purpose, runs through Stirner's work. R.W.K. Paterson notes,

What the total atheist denies (and by this stage he has become identical with the nihilist) is that our experience has any ultimate moral or metaphysical meaning. The factual regularities discovered by the scientist are ultimately inexplicable, if

${ }^{287}$ R.W.K. Paterson, The Nihilistic Egoist Max Stirner (London: Oxford University Press, 1971), 61. 
metaphysical explanation requires reference to a Suтmum Bonum purposively directing the world of brute facts; in the absence of such a directive principle, the scientific order is seen to be a metaphysical chaos. If the idea of 'God' is the idea of a unifying principle which transforms our centrifugal experiences into a coherent and significant whole, then the atheist's denial of God is a denial of the possibility of any such ideal unity. ${ }^{288}$

"Ideal unities" are akin to "essences" and can just as easily exist in the realms of the social, political, personal, or intellectual. "Belief in 'God', declares Stirner, is always the belief in a 'highest essence', whether this is supposed to be realized in the theistic God, in the spirit of Humanity, in the ideal of Love, or in the ideals of social unity and justice.”289

Indeed,

It makes no difference whatsoever to him [Stirner] whether the One God or the Triune God, the Lutheran God or the Etre Suprême, or even no God at all, but only 'Mankind', is held to represent the highest essence; for in his eyes these servants of a highest essence are all religious men, the ranting atheist no less than the most devout Christian.' Nor does it make any difference to him, Stirner would add, whether the democratic State or the socialist society, personal relationships or abstract justice, Love, Freedom, or Duty, is held to represent the highest essence; for if these ideals are put forward as 'sacred' ideals transcending, in their infinite perfection, the finite and fallible individuals whose 'worship' they claim,

${ }^{288}$ Ibid, 214.

${ }^{289}$ Ibid, 215. 
then they are religious ideals, and the fanatical democrat and socialist, the fanatical lover, libertarian, and moralist, are all equally religious men. ${ }^{290}$

Stirner emphatically rejects any "totalizing" or overarching conceptions concerning just about everything. He "sharply reminds critics" that

...the only human reality is the reality of the specific, concrete individual, in all his immediacy, and that the individual is gross body as well as pure thought, a 'whole fellow,' with intellectual interests undoubtedly, but also with sensuous, emotional, financial and many other interests, all of them equally valid for pursuit, and all of them interests, unintelligible without their reference to a living, acting self who is conscious of them as interests for him. ${ }^{291}$

Difficulty arises because Stirner would like to overcome all these "fixed ideas," and particularly those concerning our conceptions of ourselves. In order to do this he must reject the guiding ideas that both underlie our understandings of ourselves as well as the conceptual frame that structures the power, privilege, and authority he seeks to undermine. These notions are often understood in opposition to each other. We can find it difficult to have an idea of freedom without some conception of a lack thereof. In a clear precursor to Derridean deconstruction, Stirner struggles with the question of overcoming a stifling existence structured by oppositions. ${ }^{292}$

\footnotetext{
${ }^{290}$ Ibid.

${ }^{291}$ Ibid, 195-6.

${ }^{292}$ Derridean "deconstruction" most famously identifies the problems associated with these "binaries." See Jacques Derrida, Of Grammatology, trans. Gayatari Chakravorty Spivak (Baltimore: Johns Hopkins
} 
Indeed, as Leopold notes in commenting on Stirner's magnum opus,

...Stirner 'will hear nothing of this cutting in two' (p.32) and insists that alienation can only be overcome by rejecting the human essence of the 'liberals' as the enemy of selfhood rather than its true content and aspiration - as the striking epigraph to the Second Part has it, 'Man', as well as God, must die. In its place Stirner seeks to rehabilitate the prosaic and mortal self, the 'in-man [Unmensch]' for whom the notion of a 'calling' is alien, the 'man who does not correspond to the concept man' (p. 159). For Stirner, because there are no universal or prescriptive elements in human nature, the concept cannot ground any claim about how we ought to live...Rather, we need to learn, as Stirner's Nietzschean injunction has it, to give up our 'foolish mania to be something else' (p. 149) and become what we are. ${ }^{293}$

Stirner is clear in his distaste for the arbitrary limitations of language and essentialisms of all kinds. His aversion to classical liberalism emanates from the same place as his critique of systemic thinking generally. On the one hand he rejects liberalism's foundational philosophical anthropology and on the other deconstructs its edifying "truths." Stirner notes that,

Liberalism simply brought other concepts on the carpet; human instead of divine, political instead of ecclesiastical, 'scientific' instead of doctrinal, or, more

University Press, 1997). See also Derrida, Positions, trans Alan Bass. (Chicago: University of Chicago Press, 1982).

${ }^{293}$ Stirner, xx-xxi. 
generally, real concepts and eternal laws instead of 'crude dogmas' and precepts. $^{294}$

These human, political, scientific "real concepts" and "eternal laws" aim at a certain kind of domination for Stirner. Stirner warned that "[Liberalism's] aim is a 'rational order', a 'moral behaviour', a 'limited freedom', not anarchy, lawlessness, selfhood. But if reason rule [sic], then the person succumbs." 295

Stirner is referring to how we succumb to a certain intellectual domination that dresses itself in the liberating veneer of liberalism and humanism. Stirner refers to the shackling effect of the flowery discourse of "man" and "truth." According to Stirner, the Enlightenment inspired liberalism of the eighteenth and nineteenth centuries privileges essentialist ideas of humanity and truth which serve to further univocal claims about ostensibly universal values like progress and justice. He warns, "He who is infatuated with man leaves persons out of account so far as that infatuation extends, and floats in an ideal, sacred interest. Man, you see, is not a person, but an ideal, a spook." ${ }^{, 296}$

These "spooks" serve as the ghastly foundation to what Stirner sees as an inherently oppressive intellectual world. To structure the heights of informed opinion on such a precarious and artificial base represents for Stirner a colossal danger to our freedom. The divide we pretentiously further between the sphere of the intellect and everything else (the material world, including our bodies) sinks us ever deeper into our

\footnotetext{
${ }^{294}$ Stirner, 88.

${ }^{295}$ Stirner, 96.

${ }^{296}$ Stirner, 72.
} 
dominion and further exacerbates the ludicrous ideals on which we construct our material and social worlds.

Stirner's insight, though anticipating Marx's famed critique of liberal ideology, goes beyond Marx's injunction against ideology's justificatory function in the exploitation and alienation inherent in capitalism. While Marx replaces liberal ideas of human nature and natural rights with ideas of "species being" and historical materialism, Stirner rejects these ideational foundations of social life altogether. Stirner and others in the postfoundationalist tradition see these ideational foundations themselves as oppressive rather than emancipatory. While Marx ironically accused Stirner of being just another idealist in the Hegelian vein, ${ }^{297}$ Stirner could not have been clearer in his distaste for the primacy of ideas.

The reasoning behind his view is neatly framed in The Ego and its Own. Stirner notes,

Men are sometimes divided into two classes: cultured and uncultured. The former, so far as they were worthy of their name, occupied themselves with thoughts, with mind, and (because in the time since Christ, of which the very principle is thought, they were the ruling ones) demanded a servile respect for thoughts recognized by them. State, emperor, church, God, morality, order, are such thoughts or spirits, that exist only for the mind. A merely living being, an animal, cares as little for them as a child. But the uncultured are really nothing but

\footnotetext{
${ }^{297}$ See Marx, The German Ideology.
} 
children, and he who attends only to the necessities of his life is indifferent to those spirits; but, because he is also weak before them, he succumbs to their power, and is ruled by - thoughts. This is the meaning of hierarchy...Hierarchy is dominion of thoughts, dominion of mind! $!^{298}$

By internalizing these ideational foundations we not only serve the interests that seek to dominate us but also equally dominate ourselves.

This idea is similar to what Ludwig Feuerbach understood as the nature of modern thought that simply projected the qualities of God onto our atheistic humanism and thus shackled us to an anthropocentric foundationalism. According to Feuerbach, theology has been thoroughly "rationalized." The idea of God in modern philosophy reflects the preoccupation with reason and not with any spiritual attributes of the creator. ${ }^{299}$ The necessity of God is itself a manifestation of God's rationality and intelligence. ${ }^{300}$ Indeed, "It is, thus, an innate characteristic of God's own essence that he is a object of no being other than man...But, if God is only an object of man, what is revealed to us in his essence? Nothing but the essence of man."

Likewise, arguing against the intellectualism inherent in this anthropocentrism Feuerbach emphasized the role of emotions in thinking. He held that an ideal like Reason

\footnotetext{
${ }^{298}$ Stirner, 68.

${ }^{299}$ Ludwig Feuerbach, Principles of the Philosophy of the Future, trans. Manfred H. Vogel (Indianapolis: Hackett Publishing, 1986), 6.

${ }^{300}$ Ibid, 7.

${ }^{301}$ Ibid, 10.
} 
is lauded only because it is privileged in the lives of those theorizing about it. ${ }^{302}$ In other words, "The philosophers who led lives in which reason was itself dominant over feelings and actions simply projected the structure of their own lives onto the world." ${ }^{303}$

Moreover, like Stirner and Nietzsche, Feuerbach highlighted the importance of the sensuous. He noted, "Truth, reality, and sensation are identical. Only a sensuous being is a true and real being." ${ }^{304} \mathrm{He}$ continued, "The unity of thought and being has meaning and truth only when man is comprehended as the ground and subject of this unity." 305 According to Feuerbach, the sensuous should ground (in more ways than one) our endeavor to be thinking beings. In an eloquent critique of the kind of intellectualism James later interrogated, Feuerbach recommended we,

Desire not to be a philosopher, as distinct from a man; be nothing else than a thinking man. Do not think as a thinker, that is, with a faculty torn from the totality of the real human being and isolated for itself; think as a living and real being, as one exposed to the vivifying and refreshing waves of the world's oceans. Think in existence, in the world as a member of it, not in a vacuum of abstraction as a solitary monad, as an absolute monarch, as an indifferent,

\footnotetext{
302 ibid, 30-31.

${ }^{303}$ ibid, xxii.

${ }^{304}$ ibid, 51.

${ }^{305}$ ibid, 67.
} 
superworldly God; then you can be sure that your ideas are unities of being and thought. $^{306}$

However, Feuerbach remains within a nominalist framework - that is, within a mode of thought that denies the existence of abstract objects but nevertheless recognizes their pragmatic or cognitive value and "existence" as terms. Such a framework adequately helps Feuerbach convey his appreciation for sensuous and natural existence and thereby does not fully embrace the utter rejection of all idealized concepts, as does Stirner.

Common to all these thinkers who echo Stirner's sentiments is an effort to deflate the grandiose pretensions of intellectualistic discourse. While John Locke and other Enlightenment thinkers sought to demystify the pretended sophistication and grandeur of government and the Church, Stirner sought to naturalize our understanding of philosophy as just another misguided mode of thought. According to Stirner, philosophy itself served as a tool by which we inadvertently dominate ourselves.

Such a claim to self-domination would strike some as nonsensical. How can we dominate ourselves? The key to understanding this is to unpack Stirner's notion of autonomy. Stirner does not conceive autonomy in Kantian terms, as rational human will. That is, while Kantian morality entails a foundational law (the Categorical Imperative) derived from our most prized faculty ${ }^{307}$, and where immorality is irrational, Stirner thinks self-legislation is still comprised of two misguided concepts, namely the Self and legislation.

\footnotetext{
${ }^{306}$ Ibid.

${ }^{307}$ See Immanuel Kant, Groundwork of the Metaphysics of Morals, ed. Mary Gregor (Cambridge: Cambridge University Press, 1997).
} 
For Stirner, we should no more be governed by the will of another than by our own rational self-legislation. This is especially the case when that self-legislation is premised on idealized renderings of man and his potential imported from the sphere of religion and God. Stirner notes, "The ghost has put on a body, God has become man, but now man is himself the gruesome spook which he seeks to get behind, to exorcize, to fathom, to bring to reality and to speech; man is - spirit."${ }^{, 308}$

This apparent self-legislation is an effect of the intellectual domination we endure and a consequence of the humanism we embrace. Our rational will requires as much faith and submission to religiosity as any belief in God. Indeed,

What Stirner sought to demonstrate is the ultimate identity of total atheism and total egoism. If atheism is a theological denial, it is also an ethical and social denial. If it is man's escape from the clutches of an alien Deity, it is also the individual's escape from the alien authority of the State, society, and his fellow men. ${ }^{309}$

The tragedy for Stirner is we succumb to this "self-legislation" willingly and utterly convinced of our freedom in doing so. Not unlike Marx's "false consciousness," Stirner seeks to highlight this tragic element of intellectualism while rejecting any alternative or underlying emancipatory formula that Marx and other radical thinkers would propose. In the process of constructing conceptual frameworks that ground our

\footnotetext{
${ }^{308}$ Stirner, 41.

${ }^{309}$ Paterson, 216.
} 
very ideas of freedom, we are depriving ourselves of an opportunity to even fathom or experience freedom in any concrete sense.

Perhaps most importantly, the primary sin of humanism in this sense is the positing of a "self" that strives for freedom to begin with. Stirner avoids using such language of "selfhood," opting instead for the "I." Indeed, "The I is the foundation, but because the I is what remains outside any abstraction and that which is constantly eludes conceptualization, it is, at the same time, an anti-foundation." ${ }^{\text {,310 }}$ The "I" is a sort of "creative nothingness" that should elude surrender to any abstraction or illusion, "including the illusion of an ideal, unified self.",311

The trajectory of Stirner's interventions seeks to steer us away from the ethereal and towards the importance of "life." Stirner notes, “...the life turned away from things, the spiritual life, no longer draws any nourishment from nature, but 'lives only in thoughts', and therefore is no longer 'life', but - thinking." ${ }^{312} \mathrm{He}$ is certain of the impoverishing quality of the vita contemplativa. Instead, he highlights the liberating effects of the immediacy of a life intimate with and indistinguishable from nature. In pointing to this "pre-intellectual" paradigm of being, Stirner harkens back to our childhoods.

\footnotetext{
${ }^{310}$ Banu Bargu, "Max Stirner, Postanarchy avant la letter" in How Not To Be Governed: Readings and Interpretations from a Critical Anarchist Left, ed. Jimmy Casas Klausen and James Martel (Lanham: Lexington Books, 2011), 107.

311 Jesse Cohn, Anarchism and the Crisis of Representation: Hermeneutics, Aesthetics, Politics. Selinsgrove (PA: Susquehanna University Press, 2006) 126.

${ }^{312}$ Stirner, 24.
} 


\section{Stirner notes,}

For little children, just as for animals, nothing sacred exists, because, in order to make room for this conception, one must already have progressed so far in understanding that he can make distinctions like "good and bad", "warranted and unwarranted"; only at such a level of reflection or intelligence - the proper standpoint of religion - can unnatural (that is, brought into existence by thinking) reverence, "sacred dread", step into the place of natural fear. To this sacred dread belongs holding something outside oneself for mightier, greater, better warranted, better; the attitude in which one acknowledges the might of something alien, not merely feels it, then, but expressly acknowledges it, admits it, yields, surrenders, lets himself be tied (devotion, humility, servility, submission). ${ }^{313}$

We see these sentiments mirrored in James' appraisal of intellectualism when he notes, ...to the philosophic tradition which treats logos or discursive thought generally as the sole avenue to truth, that to fall back on raw unverbalized life as more of a revealer, and to think of concepts as the merely practical things...comes very hard. It is putting off our proud maturity of mind and becoming again as foolish little children in the eyes of reason. ${ }^{314}$

It is this self-imposed "surrender" that resigns us to a "life" of intellectualism and imprisons us in a framework of the ideal. According to Stirner this traps us in an

\footnotetext{
${ }^{313}$ Stirner, 67.

${ }^{314}$ James, A Pluralistic Universe.
} 
existence justified by argumentation, rational reflection, and a deluded sense of existential certainty; it is the opposite of freedom in any real sense. Stirner, like Nietzsche after him, sought to unravel the domination inherent in our intellects and free us from the limitations imposed by morality, religion, truth, and other such "fixed ideas."

\section{Friedrich Nietzsche, Anti-Authoritarianism and Anti-Intellectualism}

Nietzsche is best known as a relativist, nihilist, and aphoristic thinker who prioritized life itself rather than the narrow academic philosophical concerns of his time. He challenged Christianity and traditional morality and concerned himself with our concrete this-worldly existence rather than the ethereal and otherworldly. By dismissing the philosophical tendency to celebrate the utility, functions, or promise of knowledge to rival our existence Nietzsche embodied the anti-intellectualism central to any consistent anti-authoritarianism. ${ }^{315}$

Nietzsche best embodies this move towards anti-intellectualism and echoes Stirner in noting, "life is not an argument." ${ }^{316}$ Indeed, Nietzsche battled against the engrained appeals to logic in the history of philosophy. He does so not in an effort to dismiss logic's utility or force but rather admonishes those who pretend that an appeal to logic and the enabling faculty of reason are pathways to a discernment of reality. For Nietzsche, matters of logic apply only to fictitious entities we have created. This makes it easier to render the world "formutable [sic] and calculable" to us. In this sense, logic, like

\footnotetext{
315 For a great overview of Nietzsche on these topics and others see Walter Kaufmann, Nietzsche: Philosopher, Psychologist, Antichrist (Princeton: Princeton University Press, 1950).

${ }^{316}$ Friedrich Nietzsche, The Gay Science with A Prelude in German Rhymes and an Appendix of Songs, trans. Josephine Nauckhoff and Adrian Del Caro, ed. Bernard Williams (Cambridge: Cambridge University Press, 2001), 117.
} 
reason, is instrumental and geared towards utility. For Nietzsche, "logic" is a symptom of an idealized and artificial notion of reason itself. ${ }^{317}$

This idealized faculty does not exist independently of the schema it conjures, or more importantly, those who conjure it. Nietzsche does not attribute an independent existence to reason, only a relative or relational one. That is to say, Nietzsche holds that reason is not an ideal existing independently of those who fabricate it. Reason is itself a product of our primal urges, needs, passions, and desires and is adapted, applied, and morphed according to context. Nietzsche notes there is a "misunderstanding of passion and reason, as if the latter were an independent entity and not rather a relationship between different passions and desires; and as if every passion did not have in it its quantum of reason."318 According to noted Nietzsche scholar R.J. Hollingdale, "Such a view of the nature of thought conflicts with any idea involving its objective validity: it abolishes the 'faculty' of thought altogether, and thus calls in question the objective validity of the 'science of reasoning', logic., 319

For Nietzsche, fixation with logic and the faculty of reason is reflective of a narrow understanding of the limits of our cognition. In The Will to Power Nietzsche criticizes Aristotle's law of contradiction by divorcing logic from truth. He notes, "We are unable to affirm or deny one and the same thing: this is a subjective empirical law, it

\footnotetext{
${ }^{317}$ R.J. Holingdale, "Theories and Innovations in Nietzsche: Logic, Theory of Knowledge and Metaphysics” in Peter R. Sedgwick, ed. Nietzsche: A Critical Reader (Cambridge: Blackwell, 1995$), 112$.

${ }^{318}$ Friedrich Nietzsche, The Will to Power, trans Walter Kaufmann and R.J. Hollingdale, ed. Walter Kaufmann (New York: Vintage, 1968), 208.

${ }^{319}$ Hollingdale, “Theories and Innovations in Nietzsche," 111.
} 
is not the expression of any 'necessity' but only of an inability. ${ }^{, 320}$ Interestingly enough, this insight anticipates recent findings in quantum physics and the social scientific import of such discoveries. While advances in quantum science have enabled us to, indeed, "affirm and deny one and the same thing" (as is the case with discovering the location(s) of electrons), such indeterminacy is said to have some impact on our comprehension of the social world. ${ }^{321}$

Such a fixation is also reflective of an underlying psychological weakness. We seek to tame reality to fit our own comforting illusions because "familiarizing something unfamiliar is comforting, reassuring, satisfying, and produces a feeling of power as well. ${ }^{, 322}$ So, Reason is not a reflection of our strength as thinking beings or cunning animals but rather betrays our ultimate weakness as a species. We employ Reason to make our lives easier not because we are strong enough to decipher reality and adapt it to our needs but rather because we are too cowardly to recognize our need to decipher reality is already a symptom of our psychological weakness.

In this line of thought, Nietzsche also anticipates constructivist renderings of reality by arguing for a metaphysical world of our making. ${ }^{323}$ Indeed, thinking itself is possible only if we "assume being: logic handles only formulas for what remains the

\footnotetext{
${ }^{320}$ Friedrich Nietzsche, The Will to Power, 279.

${ }^{321}$ For an example see Alexander Wendt, "Social Theory as Cartesian Science: an autocritique from a quantum perspective" in Stefano Guzzini and Anna Leander, ed., Constructivism and International Relations: Alexander Wendt and his Critics (New York: Routledge, 2006).

${ }^{322}$ Friedrich Nietzsche, The Anti-Christ, Ecce Homo, Twilight of the Idols and Other Writings, ed. Aaron Ridley and Judith Norman (Cambridge: Cambridge University Press, 2005) 179.

${ }^{323}$ Hollingdale, "Theories and Innovations in Nietzsche", 112.
} 
same" but this assumption "is part of our perspective." Because "the world is in a state of becoming" and "knowledge and becoming exclude one another," "'knowledge' must be something other than knowledge: 'there must first be a will to make knowable, a kind of becoming must itself create the deception of beings. ${ }^{324}$ That is to say, in order for to have knowledge a fathomable and effable notion of knowledge itself must exist. This notion itself, in turn, informs the content of knowledge.

In other words, the production of knowledge involves constructing a framework for understanding and having that framework inform the content of what is known. In this way, employing cognitive tools already informed by our idea of knowledge produces knowledge itself. Our framework for understanding is already our idea of knowledge. In creating the "illusion of beings" we will the production of knowledge and a desire for it. Here, knowledge is an effort to order our constructed forms of understanding to suit understanding of other constructed "things." In this sense, "knowledge" is not "to know" but to "schematize." ${ }^{325}$ Such systematization should always be scrutinized. Nietzsche notes, "I distrust all systematizers and avoid them. The will to a system is a lack of integrity." 326

Correspondence to some concrete reality or coherence between concepts or, as Stirner would call them, "fixed ideas" does not undergird Nietzsche's theory of truth.

\footnotetext{
${ }^{324}$ Friedrich Nietzsche, The Will to Power, 280.

${ }^{325}$ Hollingdale, “Theories and Innovations in Nietzsche," 115.

${ }^{326}$ Friedrich Nietzsche, The Anti-Christ, Ecce Homo, Twilight of the Idols and Other Writings, 159.
} 
Knowledge entails little about truth and truth little about knowledge. In writing on the “origin of knowledge," Nietzsche notes,

Through immense periods of time, the intellect produced nothing but errors; some of them turned out to be useful and species-preserving; those who hit upon or inherited them fought their fight for themselves and their progeny with greater luck. Such erroneous articles of faith, which were passed on by inheritance further and further, and finally almost became part of the basic endowment of the species, are for example: that there are enduring things; that there are identical things; that there are things, kinds of material, bodies; that a thing is what it appears to be; that our will is free; that what is good for me is also good in and for itself. Only very late did the deniers and doubters of such propositions emerge; only very late did truth emerge as the weakest form of knowledge.

Nietzsche continues, "Thus the strength of knowledge lies not in its degree of truth, but in its age, its embeddedness, its character as a condition of life." ${ }^{, 327}$ The life serving functions of knowledge have elevated its pursuit to rival existence itself. Here is where Nietzsche finds both fault with the idea of knowledge and its utility. Knowledge became crucial to survival; it complemented our cleverness in its ability to aid our thriving. It also reflected our weakness as psychologically stunted creatures that needed the reassurance of permanence over flux. In any case, knowledge is artificially imposed on and distinct from the life it helps preserve and the urges, desires, and passions it seeks to map, delimit and order.

\footnotetext{
${ }^{327}$ Nietzsche, The Gay Science, 110.
} 
Logic has even less of a relation to either truth or knowledge. Nietzsche questions,

What is the origin of logic in man's head? Surely it arose out of the illogical, the realm of which must originally have been immense. But innumerable beings drew inferences in a way different from that in which we do now perish; nonetheless, they might have been closer to the truth! $!^{328}$

"Truth" in these scenarios is incidental. We do not arrive at it in any systematic way nor even know much about when and how we approximate it. There is both a certain impenetrability of reality and limits to our cognitive ability to fathom such penetration. The best that can be hoped for is the practical benefit of knowledge acquisition and an understanding that knowledge itself is artificial.

Nietzsche's point is to stress the occasional utility of notions like truth and the employment of logic without attributing metaphysical veracity to their claims. After all, Nietzsche notes,

We have arranged for ourselves a world in which we are able to live - by positing bodies, lines, planes, causes and effects, motion and rest, form and content; without these articles of faith no one could endure living! But that does not prove them. Life is not an argument; the conditions of life might include error. ${ }^{329}$

\footnotetext{
${ }^{328}$ Ibid, 112.

${ }^{329}$ Ibid, 117.
} 
Nietzsche questioned the idea that we could ever reach an objective truth. He saw objective truth as a symptom of the evolution of philosophy. He saw it as a contingency of certain modes of thinking and instead embraced perspectivism as an appropriate mode of "knowing" and dismissed the "knowledge" of knowledge as nonsensical. $\mathrm{He}$ considered philosophers guilty of "concept idolatry" 330 and in Twilight of the Idols refers to Kant as a "concept cripple." 331

Nietzsche reacted to what he saw as the reverence for "rational truth" and the "virtue and happiness" associated with it in the Platonic tradition. The ultimate result of this, according to Bruce Detwiler, is "our modern passion for objective truth, with its underlying assumption that scientific knowledge is not only valuable but more valuable than anything else. ${ }^{332}$ This view is misguided according to Nietzsche. In section 374 of The Gay Science Nietzsche notes that "we cannot look around our own corner," and "we cannot reject the possibility that [the world] may include infinite perspectives." Indeed, "the human intellect cannot avoid seeing itself in its own perspectives, and only in these," we cannot know "how far the perspective character of existence extends or indeed whether existence has any character other than this." ${ }^{, 333}$

We can therefore not fathom the extent of our knowledge of "facts." We are inextricably tied to our perspective knowing. Our understanding is always incomplete and

\footnotetext{
${ }^{330}$ Nietzsche, The Anti-Christ, Ecce Homo, Twilight of the Idols and Other Writings, 167.

${ }^{331}$ Ibid, 191

${ }^{332}$ Bruce Detwiler, Nietzsche and the Politics of Aristocratic Radicalism (Chicago: The University of Chicago Press, 1990), 74.

${ }^{333}$ Nietzsche, The Gay Science, 239.
} 
partial. Moreover, Nietzsche claims we endeavor only to further certain perspectives against competing internal drives and external adversaries. "Facts" of the matter actually matter little. Nietzsche argues, "Facts is precisely what there is not, only interpretations." Indeed, "It is our needs that interpret the world; our drives and their For and Against. Every drive is a kind of lust to rule; each one has its perspective that it would like to compel all other drives to accept as a norm." ${ }^{334}$

Hence, we have Nietzsche's preference for "Nature" over "Life." By Nature, Nietzsche means our ephemeral passions and instincts grounded in unmediated existence. By Life Nietzsche means the derivative faculties of clever animals like us that shape, organize, reify, and master Nature for our own invented ends. Indeed, "Whereas Nature is boundless, indifferent and amoral, Life remains bounded by a horizon of anthropocentric preferences and values." 335

Nietzsche's view of Nature is value-free. As Daniel W. Conway notes, Nietzsche “...endows the Nature to which he 'returns' with no positive content or character... Nature is simply whatever remains when all super-natural principles of interpretation have been subtracted from our understanding of the world." ${ }^{, 336}$ The absence of supernatural principles of interpretation or constructed frameworks of understanding attracts Nietzsche to the demystified and this-worldly concreteness of natural existence (as opposed to idealized Life).

\footnotetext{
${ }^{334}$ Nietzsche, The Will to Power, 267.

${ }^{335}$ Daniel W. Conway, "Returning to Nature: Nietzsche's Gotterdammerung” in Nietzsche: A Critical Reader, ed. Peter R. Sedgwick (Cambridge: Blackwell, 1995), 39.

${ }^{336}$ Conway, "Returning to Nature," 42.
} 
We can see a parallel between Nietzsche's contempt for God (and its secular stand-in Reason) and his disdain for Life and its ethical and metaphysical foundations. Both attempt to fill a void caused by our psychological weakness. For example Nietzsche considers our attempts at social justice as nothing more than an expression of a secular and moral stand-in for the almighty. Indeed, explains Detwiler,

Because most of us cling to moral assumptions and their political corollaries, which depend for their validity upon a God we have largely repudiated, Nietzsche characterizes modernity as an age of 'incomplete nihilism.' In spite of the death of God a secular gospel of brotherly love and egalitarianism still flourishes... ${ }^{337}$

There seems to still be a need for some kind of transcendent grounding because most "people resist total nihilism not simply because they are obtuse but because they are psychologically incapable of coming to terms with it.",338

The competing drives that animate our nihilistic existence exercise authority over each other by force and not by any reasoned consideration of utility, expediency, or verity. Though Nietzsche seems to embrace the naturalness of these competing drives he couches this embrace in a thorough rejection of the edifying frameworks of understanding that seek to justify or judge their authority or existence.

In declaring that God is dead, Nietzsche refers to "the new realization that there is no objective order, meaning, or ethical significance inherent in existence. Rather, man

\footnotetext{
${ }^{337}$ Detwiler, Nietzsche and the Politics of Aristocratic Radicalism, 130.

${ }^{338}$ Ibid.
} 
himself has always been creator of his own meanings, usually without realizing it." 339 While accepting such a circumstance, Nietzsche affords this reality an ironic absence of certainty or authoritative account, instead relying on infinite "perspectives."

We should consider Nietzsche as a thinker who destabilized the epistemological and ontological landscape in ways that opened opportunities for upstarts, rebellions, and outright revolutionary thought that interrogates its own presuppositions and hidden sources of arbitrary authority and privilege. Nietzsche, Stirner, and their interlocutors have helped highlight what is authoritarian about Reason (both as an ideal and as a privileged faculty) and paved the way towards postfoundationalist anti-authoritarianism of the intellect.

\section{Anti-Authoritarianism, Anti-Intellectualism and "Non-Political" Domination}

While there is little disagreement in thinking of Stirner and Nietzsche as ontological and epistemological anti-authoritarians, there is resistance to thinking of them as politically anti-authoritarian. This is with good reason. Their radicalism is often interpreted as politically apathetic, an apology for the bourgeoisie or as an unabashed elitism. While Marx lambasted Stirner for his idealism and for playing into the hands of the bourgeoisie, Nietzsche has long been considered a reactionary and an inspiration for Fascism. ${ }^{340}$ Likewise, many more "interpretations seem possible: between the racial enthusiasms of national socialism, the still encountered dedication of those trying to live

\footnotetext{
${ }^{339}$ Ibid, 155.

${ }^{340}$ For examples, See Golomb, Jacob, and Robert S. Wistrich, ed. Nietzsche, Godfather of Fascism? On the Uses and Abuses of a Philosophy (Princeton: Princeton University Press, 2002).
} 
a la Demian, a 'Nietzschean' life, the bright individualism of most Anglo-American interpretations, and the dark cosmic mysteries offered by Continental philosophers." "341 Appropriated by Nazi propagandists as an inspiration for the fiercely agonistic great power politics of the first half of the $20^{\text {th }}$ century and also interpreted as offering a foundation for the cutthroat individualism of unfettered capitalism, both Stirner and Nietzsche seem susceptible to the idea of our domination over each other.

However, I argue their thought can be channeled either politically or apolitically. Or, as I note, their ideas can be exercised in political ways to challenge orthodoxies in ostensibly non-political spheres and, moreover, serve as critical intellectual linchpins to the postfoundationalist and anarchist traditions. Stirner and Nietzsche represent seminal figures in the history of anti-intellectualism and frame the issues which later anarchist and postanarchist scholars and activists tackled.

For Nietzsche, many of our conceptualizations (e.g., about human nature, rationality, free will) seek to justify a certain "form of life" and legitimize that over which “this form of life has sway." Indeed, as Tracy Strong notes, conceptualizations are "thus a manner of preserving a certain pattern of domination and of enforcing a legitimacy for a certain set of horizons, without it ever appearing necessary to seek justification for that enforcement." 342

\footnotetext{
${ }^{341}$ Tracy B. Strong, Friedrich Nietzsche and the Politics of Transfiguration (Berkeley: University of California Press, 1975), vii-viii.

${ }^{342}$ Ibid, 67.
} 
Such a characterization of Nietzsche echoes classical anarchist concerns about the self-referential justificatory quality of the state. The argument is as follows: The state is legitimate because it exists. The sovereign authority already imposed on those who think otherwise than the state already ipso facto delegitimizes thinking otherwise than the state. Granted, there are countless justificatory frameworks that legitimize governments (and rebellion against it) but the horizon of legibility (to invoke James Scott) remains the state form. ${ }^{343}$ In other words, even when resisting government the sovereignty of the state remains and is unquestioned. Moreover, such resistance is usually couched in an appeal to constitutionalism, liberty or equality vis-à-vis the state, rights discourse sanctified by the state, or even the mythological origins of the state. Any resistance alien to this statecentric framework that does not already recognize the legitimacy of the state (though could perhaps not recognize a specific government presiding over the state) is already, usually, considered out of bounds. Moreover, the state itself is never asked to legitimate its existence (though governments may be said to be justified by the consent of the governed). The state simply is and any resistance to its oppression or domination is usually framed legally, morally, or politically within a state-centric horizon of legibility.

In this sense, the horizon of political thought is necessarily limited to the framework of sovereign state power. These conceptual schemes are always in reaction to the state-centric framework of reference. No state will disappear for lack of "legitimacy" unless a competing justificatory narrative (or force) replaces that legitimacy. States do not simply step aside or dissolve in recognition of their own illegitimacy. Only changes

\footnotetext{
${ }^{343}$ See James Scott, Seeing Like a State: How Certain Schemes to Improve The Human Condition Have Failed (New Haven: Yale University Press, 1998).
} 
in the "forms of life" themselves will invite new justificatory schemes. Anarchists note that challenges to state authority tend to be considered ipso facto illegitimate unless grounded in some other theory of popular or individual sovereignty vis-à-vis the state, in the same way that Nietzsche diagnoses how it seems unnecessary to justify the legitimacy of arbitrary horizons of the intellect.

Tracy Strong refers to this auto-legitimization when speaking on one such limiting conceptualization, free will. He quotes Nietzsche in Beyond Good and Evil,

The doctrine of free will is a cunning method of preserving the credibility of the ego-cogito. In fact, Nietzsche writes, " "Freedom of the Will" - that is the expression of a complex state of delight of the person exercising volition.... What happens here is what happens in every well constructed and happy commonwealth: namely, the governing class identifies itself with the success of the commonwealth. ${ }^{344}$

In other words, the "ego-cogito" - like the state - privileges its own existence via certain unquestioned beliefs. In the former this belief is free will, in the latter it is the preservation and success of the commonwealth.

Likewise, Nietzsche notes that master and slave morality operate in similar ways. Slave morality is then inherently reactive and limiting in its moral and intellectual horizons. It is a reaction to master morality (which entails the affirmation of the self and the consequences of such affirmation as good and noble). While master morality entails

\footnotetext{
${ }^{344}$ Strong, 67.
} 
the affirmation of the self, slave morality reactively defines "good" as the opposite. Likewise, slave morality defines evil as the opposite of the good in master morality. The "slave morality" prevalent in modern thinking depends on an intellectual horizon set by others. It hinges on "master morality" and so lacks the creative character Nietzsche admired. Nietzsche sought first to identify this "soil," or the unquestioned ground set by others, on which such values sprouted, and then to overcome their limiting horizons and highlight the "creative character of thinking."

It was Nietzsche's aim to supersede what was considered the most rigorous thought - philosophy. Of course, this rigor was grasping at straws according to Nietzsche. It was a pretended rigor that had no chance of attuning itself to its ostensible aims (e.g., truth, reality). It was an ostensible rigor that had no basis in any underlying reality but rather was a reflection of our own psychological weakness and need for certainty. According to Nietzsche, the project of "knowledge" seeking in philosophy is Sisyphean. What was needed was not seeking but thinking. Jane Bennett and William Connolly note,

Nietzsche...thought about the layered and creative character of thinking in a way that pulls it past the mechanical determinism of reductionists, the transcendentalism of two-world metaphysicians, and the teleological model advanced by those who cannot fold nature into culture without investing it with a final purpose. Thinking for Nietzsche involves a complex process of discord and coordination between multiple theaters of activity. As he puts it, "the chamber of consciousness is small,' too small to perform the complex task of thinking by 
itself. 'Conscious thinking, especially that of the philosopher, is the least vigorous and therefore also the relatively mildest and calmest form of thinking; and thus precisely philosophers are most apt to be led astray about the nature of knowledge. ${ }^{345}$

Nietzsche held that philosophers are led astray because they artificially impose a constructed relating of reality onto both our ideas of that reality and our intellectual impetus for action within it. Jane Bennett and William Connolly aptly describe how this process unfolds.

These linguistic equalizations enter into habits, organic functions, institutional regimes and the experimental designs of science. Moreover, they become corporeally encoded in patterns of perception and cultural vocabularies. But they are never completely stabilized. The similarities-rendered-equal and the differences-rendered-similar periodically manifest themselves as rebel forces within habits, organic functions, etc. These differential energies and energetic disturbances both enable creativity in thinking and help to propel interventions for reform of the 'laws.' The point is that somatic/cultural relays play a major role in the stabilization and destabilization of laws. So there is a side of us capable of coming to terms, though only fugitively, with dimensions of the world that

\footnotetext{
${ }^{345}$ Jane Bennett and William E. Connolly, "Contesting Nature/Culture: The Creative Character of Thinking," The Journal of Nietzsche Studies, Issue 24, Fall 2002), 158.
} 
escape, exceed, resist and destabilize the best equalizations of nature we have been able to devise and enforce. ${ }^{346}$

We seem to unwittingly react to this privileged accounting of reality and pivot our intellectual musings on its constructed framework. The anti-intellectualism I see in Stirner's and Nietzsche's thought seeks to expose such reaction and attempts to unhinge our thought from its bounds. While Stirner and Nietzsche both fit into intellectual categories (despite their earnest efforts to the contrary) that lend themselves to either political and apolitical readings, I argue that their anti-authoritarianism of the intellect serves as a bridge to the anti-intellectualist strain of postfoundationalist anarchist thought. This postfoundationalist strain identifies the domination inherent in and compels us to combat authoritative accounts of intellectuality, thought, and philosophy for non-political ends. Their ends are for the sake of thinking freely.

\section{Anti-Intellectualism, Post-Foundationalism and the Anarchist Project}

Stirner and Nietzsche combat these forms of intellectual domination by pointing to the totalizing effects of humanist and liberal discourse despite their anti-authoritarian ethos. While Stirner and Nietzsche have no recourse but to express their thought with language, ideas, concepts, etc. they consciously qualify and openly reject the sagacity of their own thinking by admitting to its limitations and encouraging self-reflection and independence of thought in their readers. ${ }^{347}$

\footnotetext{
${ }^{346}$ Ibid, 150.

${ }^{347}$ Perhaps the best example of this is in Nietzsche's Thus Spoke Zarathustra when Zarathustra hopes to embolden his followers to no longer follow him. Central to the idea of the superman (or overman) is the
} 
Their reevaluations of the history of philosophy lend themselves to anarchist readings where anarchism purports to dismantle sites of arbitrary authority, power and privilege. Stirner and Nietzsche identify sites of arbitrary authority, power and privilege in epistemology and ontology while their anarchist interlocutors intend to dismantle the political, economic, and cultural sites of domination structured by them. These sites of intellectual domination stifle both free thought and genuinely creative endeavors according to these two anti-foundationalist thinkers. Both thinkers are philosophers of creation and on this point they also converge with the anarchist tradition.

Both thinkers offer an account of creative destruction (Nietzsche of metaphysics and values, Stirner of all "fixed ideas") that complements the Romantic impulse that animates the postfoundationalist tradition. This tendency also reflects the "passion for destruction" which animated Mikhail Bakunin and also informs the "creative passion" of thinking freely. ${ }^{348}$ In the anarchist context, Saul Newman has referred to this general outlook as turning anarchism on itself. Newman thought of this process of dismantling sites of authority in the ontological and epistemological spheres as turning the political, economic, and cultural values of so-called classical anarchism against the ontological and epistemological pillars of anarchist thought.

idea of trailblazing and setting your own course. Nietzsche writes, "I now go away alone, my disciples! You too go away and be alone! So I will have it. Truly, I advise you: go away from me and guard yourselves against Zarathustra! And better still: be ashamed of him! Perhaps he has deceived you. The man of knowledge must be able not only to love his enemies but also to hate his friends. One repays a teacher badly if one remains only a pupil... Now I bid you lose me and find yourselves; and only when you have all denied me will I return to you." See Friedrich Nietzsche, Thus Spoke Zarathustra: A Book For Everyone and No One (London: Penguin, 2003), 103.

\footnotetext{
${ }^{348}$ Mikhail Bakunin writes, "The passion for destruction is a creative passion, too!" See "The Reaction in Germany," accessed 12/26/2014, https://www.marxists.org/reference/archive/bakunin/works/1842/reactiongermany.htm.
} 
Stirner and Nietzsche were both concerned with domination though not in the ways those on the political left usually envision such struggles. While the political left, most notably anarchists, recognize the dangers of concentrated political, economic, and cultural power, interlocutors of Stirner and Nietzsche in the postfoundationalist anarchist tradition highlighted the dangers of totalizing conceptual schemes and arbitrary intellectual consensus on key onto-epistemological issues. Stirner worried about the dominion of everyday thought and how it insidiously imposed arbitrary limitations on our thinking, expression, and action while Nietzsche worried about the trend towards sheepishness and allowing ourselves to be dominated by psychological weakness in the face of the grandiose intellectual ambitions of philosophy.

While Stirner, Nietzsche, and their interlocutors are also echoed in the AngloAmerican philosophical tradition with regards to the limits of philosophical thinking, they seek to go a step further than highlight the practical worth of philosophy or its relation to natural science. ${ }^{349}$ Moreover, they also seek to highlight the relevance of what are usually understood as political problems (e.g., domination, authority) to issues in metaphysics and epistemology.

Nietzsche, like Stirner, was wary of the democratic and socialist experiments of his day as hopelessly usurping individual freedom and our spontaneous urge to create

\footnotetext{
${ }^{349}$ For example, we often see echoed in Nietzsche the practical value of both science and concepts like "truth." American pragmatists and others like W.V.O. Quine and his interlocutors have stressed the relation of science to practical concerns and their relation to philosophy and logic in turn. While admitting to their practical value Nietzsche and Stirner never fail to point out their worthlessness as an attempt at acquiring "knowledge." It is this question of knowledge and the irrelevance of "beliefs" about what we may think we know that distinguishes Stirner and Nietzsche from those who held compatible views in the AngloAmerican philosophical tradition.
} 
(and destroy according to Bakunin). Anarchists too are wary of such experiments and for the same reasons. The logic of opposition to such schemes is the same. It is an opposition to grandiose conceptual mappings (even if consensual) of both social and intellectual life that respects the individuality of each and disavows us of our Promethean aspirations and Procrustean tendencies.

Anarchists seek, much like these two thinkers, what can be understood as an "aristocracy of all, where the liberty and autonomy of each is fully and equally respected." ${ }^{350}$ They seek this "aristocracy" in the context of a Heraclitean reality that accepts the "essence of life is its continuously changing character; but our concepts are all discontinuous and fixed, and the only mode of making them coincide with life is by arbitrarily supposing positions of arrest therein." Indeed it is

With such arrests our concepts may be made congruent. But these concepts are not parts of reality, not real positions taken by it, but supposition rather, notes taken by ourselves, and you can no more dip up the substance of reality with them than you can dip up water with a net, however finely meshed. ${ }^{351}$

Stirner, Nietzsche and their interlocutors guard against the authoritarian dangers of such "congruence" as well as the arbitrary and limiting force of these suppositions.

Reason and its supporting ontological notions like essentialism, human nature, and foundationalism of all kinds are usually celebrated for their emancipatory value but are derided by Stirner and Nietzsche as psychological weakness, totalizing domination,

\footnotetext{
${ }^{350}$ Saul Newman, The Politics of Postanarchism (Edinburgh: Edinburgh University Press, 2011$), 33$.

${ }^{351}$ William James, A Pluralistic Universe [iBook], lecture 6 "Bergson and His Critique of Intellectualism."
} 
and an arbitrarily limiting intellectualism. Instead, Stirner and Nietzsche served as a bridge to contemporary anarchist anti-metaphysical and, I argue, anti-intellectualist thought by embracing the sensuous and emotive qualities of life as integral to thinking and rejecting argumentation as the measure of truth or any other authoritative rendering of reality. By recognizing that the intellectualism inherent in our celebration of Reason exercises a peculiar logic only applicable to fictitious modes of being wholly divorced from these sensuous and emotive qualities, Stirner and Nietzsche intended to debunk the Enlightenment-inspired adulation of Reason and undermine the predictable intellectualism that accompanies it. 


\section{Conclusion}

\section{Towards Public Irony}

Anarchism is more than a protest against government. It is quintessentially antiauthoritarian. It challenges authority and interrogates relations of domination inherent in the inequalities and relations of domination in every realm of life. It follows that anarchism also questions epistemological and ontological authority. Those with anarchist inclinations tend to question any claim to knowledge, intellectual authority, or metaphysical finality. Nevertheless, some contemporary anarchist scholarship has stressed the notion that their classical anarchist predecessors largely ignored the dangers of the authority of Reason, science, other "foundational" concepts, and the intellectualism they engender.

To the contrary, I have argued a direct challenge to the authority of Reason, science, "foundationalisms" of all sorts, and the intellectualism they usually engender was already present in the so-called classical anarchists. In doing so, I not only revisited the sometimes-caricatured readings of the these anarchists and considered postfoundational traits they already possessed, but also critically consider the novel and heterogeneous ways anarchists and others have tackled the notion and experience of freedom. ${ }^{352}$ I discovered anarchists appeal to our private judgment in the face of established academic institutional power, they question the notion of a Reason-driven progress that was integral to the Enlightenment tradition, and they regularly challenge the

\footnotetext{
${ }^{352}$ For a detailed consideration of the relationship between anarchism, modernity and postmodernity see Nathan Jun, Anarchism and Political Modernity (London: Continuum, 2012).
} 
conceptual hegemony of supposed bulwarks of our intellect (e.g., Reason, the scientific method, univocal understandings of human nature).

In chapter one I briefly theorized employing Wittgenstein to imagine what anarchist anti-intellectualism might look like. By using what I consider as actionoriented understandings of meaning in Wittgenstein's notions of "knowing how to go on" and "rule following" I explore how to broaden our notion of freedom in anarchist philosophizing. In the rest of this work I interrogate freedom itself and its many "heterotopic logics" ${ }^{353}$ as they relate to anarchist anti-intellectualism while surveying some "paradigmatic" anarchist thinkers.

I continued the "turning" of anarchism "on itself" (as Saul Newman would say) in a reflection on the "disintegration, of transition, of waning faith in the modern ideas of Reason and Progress, and the Enlightenment project in general." ${ }^{\text {354 }}$ In reassessing the ostensible "canon" of anarchist thought I interrogated the assumptions of the postanarchist literature and connected anarchist anti-intellectualism to the anarchist approach to liberation more generally. Anarchists sought not only social and political freedom in their rejection of the legitimacy of the state, the hierarchy of the capitalist firm, and the ecclesiastical authority of the church, but also to think freely. Central to such an endeavor is a continual challenge to not only centers of political, economic, and religious authority but also a challenge to academic institutions, the celebration of Reason and science, and the foundational concepts that usually undergird them.

\footnotetext{
${ }^{353}$ Svetlana Boym, Another Freedom: The Alternative History of an Idea (Chicago: University of Chicago Press, 2010), 17.

${ }^{354}$ Gregory Bruce Smith, Nietzsche, Heidegger, and the Transition to Postmodernity (Chicago: University of Chicago Press, 1996), 8.
} 
A critique of the overconfidence in the persuasive power of reason is nothing new. Many have railed against what James C. Scott called "Seeing Like a State" and embraced his appeal to metis or the local and tacit knowledge born of and passed along by experience in order to combat the increasingly "rationalized" knowledge prioritized by the archenemies of anarchists, state systems. ${ }^{355}$ However, Anarchism is rarely considered in concert with thinkers like Wittgenstein who challenge the underlying presuppositions of meaning that sustain such critiques. The reason has much to do with the false perception that anarchists, by and large, are faithful children of the Enlightenment. Even more rarely are they considered with thinkers like Rorty or Feyerabend who explicitly rejected anarchism as a viable political system. This work also navigated anarchist philosophy with an eye towards the kind of incessant critique central to the anarchist aspiration to be "without adjectives."

An incessant critique of the foundational notions of the Enlightenment, Modernity, and even Anarchism itself seems central to theorizing within an anarchist framework. However, the drive to perpetually question seems impossible to arrest and therefore impossible to transcend within the parameters established by modernity that seems to encourage such questioning. ${ }^{356}$ The struggle to transcend such a line of critique goes beyond what Rorty called "private irony," or the incessant employment of new vocabularies to better describe and improve our self-image or understanding, because it

\footnotetext{
${ }^{355}$ See James C. Scott, Seeing Like a State: How Certain Schemes to Improve the Human Condition Have Failed (New Haven: Yale University Press, 1998).

${ }^{356}$ See Robert Pippin, Modernism as a Philosophical Problem: On the Dissatisfactions of European High Culture (Cambridge, Mass.: Basil Blackwell, 1991).
} 
requires us to relate such irony to our relations with others and the political community to which we belong. ${ }^{357}$

The process by which we make public our ironism through an anarchist framework begins with understanding the contradictions of the process itself and how the anarchist tradition has navigated it in the past. In the so-called classical anarchists we see an indefatigable faith in the idea that Reason propels progress and that Reason should be unimpeded in its exercise. Somewhat contradictorily, we also see that Reason (and intellectual authority more generally) is sometimes viewed with suspicion and critically appraised as the root of other modes of hierarchy and domination. In the anarchist tradition, the ideal of Reason, the scientific method, and the auxiliary notions usually used to sustain them are only celebrated because they are seen to contribute to freedom within certain contexts and at certain times. However, the classical anarchists also think these same ideas pose a potential hazard to freedom when unquestioningly embraced. For anarchists, an uncritical acceptance of these ideals threatens to turn the ostensible search for truth or freedom into just another idol or hierarchical enterprise.

This critique is not uniquely anarchist. The endeavor can be couched in the wider reverberations of the Enlightenment. Moreover, there were innumerable debates among schools of skeptics, subjectivists, deists, and later, romanticists and postfoundationalists concerning our most esteemed faculty of reason and the potential authoritarianism bred of

\footnotetext{
${ }^{357}$ Richard Rorty describes an ironist as one who has continuing doubts about the final vocabulary they employ, that recognizes their present vocabulary as inept to the task of overcoming these doubts, and that accepts their vocabulary (or any vocabulary) is no closer to an outside power or external reality than any other and are all contingent on the person employing said vocabulary. Willingness to reassess and "be impressed" by other vocabularies and admit those vocabularies are not connected to anything beyond ourselves. See "Private Irony and Liberal Hope" in Richard Rorty, Contingency, Irony, and Solidarity (Cambridge: Cambridge University Press, 1989), 73-95.
} 
its idealization. In order not stymie to our quest for freedom, anarchists offer twin concerns. They are wary of the arbitrary authority inherent in government, concentrations of wealth, and the church (and religion generally) as well as the questionable authority of Reason and other modes of intellectual authority. These concerns should not sacrifice freedom in one realm for freedom in another. Means and ends should be aligned. Similar to their critique of Marx's "dictatorship of the proletariat," many anarchists highlight the importance of resisting the lure of absolute authority in the realm of the intellect for the sake of some imagined liberation in other domains. In other words, we should not sacrifice ourselves to the imagined authority of mental abstractions for the sake of some progress in social and political matters. The socalled classical anarchist thinkers (especially Godwin, Proudhon, Bakunin, and Kropotkin) can all be interpreted as having this sometimes-contradictory relationship with the ideal of Reason and intellectualism. This seemingly incongruous positioning leads to interesting contrasts and overlaps with postfoundationalist thought (and its phenomenological and existential predecessors). It also highlights the line between thought and action that anarchists are often negotiating.

\section{Progress is not Synonymous with Freedom}

In Godwin and Proudhon, there is a sense that progress, and therefore freedom, is only possible through the exercise of our reason. Moreover, the ideal of Reason, which is implicated in every scheme for societal improvement in these two thinkers, is often celebrated as an authority independent of its exercise as a faculty. However, this 
celebration of our most prized faculty and the idealized constructs that are a consequence of this celebration were not absolute.

Godwin and Proudhon, like Bakunin and Kropotkin after them, struggled between notions of immanence and transcendence. While they celebrated seemingly transcendent ideals (e.g., liberty, equality, and truth) they also navigated the ephemerality of life and reflected this ephemerality in their anarchism (thus rejecting the stifling intellectualism that is often a consequence of the unquestioned obedience to transcendent ideals). ${ }^{358}$ They recognized the values that should underwrite anarchist ideals but admitted these values only existed as part of a contingent and transient reality.

Godwin's general attitude towards the celebration of Reason and the intellectualism that often follows evolved over time. His faith in the emancipatory potential of Reason in Political Justice gave way to an appreciation of the limits of Reason in his literary works. His novels demonstrate the dangers of "progressive modernity" and largely reject the evident ratiocination of Political Justice (arguably, his most famous work). ${ }^{359}$ Progressively, first in Caleb Williams and then in St. Leon and Fleetwood, Godwin offered an exaltation of fellow feeling and our natural sympathies as

\footnotetext{
${ }^{358}$ Nathan Jun writes about the struggle between immanence and transcendence in anarchist thought in his Anarchism and Political Modernity, 126-7.

${ }^{359}$ David Collings, "The Romance of the Impossible: William Godwin in the Empty Place of Reason" English Literary History, 70:3 (2003), 849.
} 
well as a rejection of overarching schemes for societal improvement and our reliance of reason for the achievement of justice. ${ }^{360}$

Likewise, Proudhon shared the excitement of the philosophes for the ideals of progress, Reason, science, and truth. He goes so far as to say that no person's will subjugates the dictates of reason. ${ }^{361}$ Indeed, Proudhon saw reason as a vehicle for and a prerequisite of liberation. Moreover, Proudhon was quite consistent in taking political economy as the Archimedean point of all inquiry. In this way, he shared Marx's axiomatic materialist ontology. However, Proudhon also came to oppose an unadulterated reverence of Reason and the unquestioned faith in the accompanying scientific methodology that Enlightenment thinkers (and Marx) often praised.

Interestingly, despite many points of agreement Proudhon and Marx vociferously disagreed over the notion of authority in the revolutionary process. It is in this area where Proudhon's views on intellectualism (and the celebration of Reason that sustains it) became most pronounced. In one of Proudhon's famous letters to Marx he exhorted the revolutionary to not become the leader of the "new intolerance" of the "religion of reason" and instead advocated we tackle a priori dogmatisms and other philosophical assumptions with "eloquence and irony." 362 For Proudhon, this eloquence and irony should inspire our interpretation of the constant interplay between abstract Reason and

\footnotetext{
${ }^{360}$ See William Godwin's, Caleb Williams (Peterborough, Ont.: Broadview Press, 2000); St. Leon: A Tale of the Sixteenth Century (New York: Arno Press, 1972); and Fleetwood, or The New Man of Feeling (Peterborough, Ont.: Broadview Press, 2001).

${ }^{361}$ Pierre Joseph Proudhon, What is Property? ed. Donald R. Kelly and Bonnie G. Smith (Cambridge: Cambridge University Press, 1994) 209.

362 Proudhon's letter to Marx is dated 17 May, 1846 and is available at Anarchy Archives, accessed May $12^{\text {th }}, 2016$, http://dwardmac.pitzer.edu/Anarchist_Archives/proudhon/letters/proudhontomarx.html.
} 
everyday experience. This interplay highlights Proudhon's consideration of experience as a process of becoming and contingency. In this way, he found life to resist fixed and absolute schematization.

While Godwin and Proudhon privileged Reason they also acknowledged its limitations and even its dangers. They grappled with the defining features of modernity, challenging the framework that grounded the Enlightenment enterprise all the while celebrating its emancipatory potential. While many of their so-called classical anarchist counterparts were readily skeptical of overarching appeals to Reason and science, Godwin and Proudhon only gradually came to challenge the intellectualism inherent in an uncritical celebration of Reason and authoritative accounts of auxiliary notions like human nature and science.

\section{Science and the Scientific Method Enable Freedom - or Do They?}

Bakunin and Kropotkin were openly skeptical of Reason and the intellectualism associated with it throughout their work. While Bakunin and Kropotkin celebrated the scientific method they also diagnosed an intellectual monomania that relied exclusively on Reason and science to bring about revolution. According to them, these obsessions led to the formation of hierarchically institutionalized forms of scientific discovery, the dogmatism of a univocal "rationalism," and an alienation from everyday living bred from a firm division of "intellectual" and manual labor.

It is clear Bakunin did not consider himself a systematic thinker. He once emphatically pronounced that he "cleaved to no system" and he was therefore a "true 
seeker." ${ }^{363} \mathrm{He}$ respected the authority of experts but always reserved his "incontestable right of criticism and censure" because he recognized "no infallible authority" for such a recognition would be fatal to his "reason," "liberty," and the success of his undertakings and would make him into a "stupid slave, an instrument of the will and interests of others. ${ }^{\not 64}$ Moreover, he forcefully rejected the auto-legitimating character of scientific "progress" and the pretense of the intellectuals associated with it.

Likewise, while Kropotkin is the representative of "scientific anarchism," he thought anarchism itself was anathema to any institutionalized, scientific, or philosophical rendering of social relations. While Kropotkin did rely on the scientific observation of animal behavior in nature to inform his theory of mutual aid, he clearly delineated the limits of such intellectual endeavors as divorced from our lived experience. Kropotkin's anarchism was based on naturally occurring cooperative tendencies in human life and relied on scientific accounts of the same all the while recognizing the need to guard against the institutional logic (bred of authoritarian tendencies) of scientific associations and universities.

In Bakunin and Kropotkin, a disdain for the intelligentsia and a critical treatment of the ideal of Reason existed alongside an appreciation of our most esteemed faculty and science. While they were aware of their dangers they were outraged at the abuses of an idealized Reason and excessive fidelity to science. Those abuses, and the dangerous authoritarian consequences that followed, were products of the intellectuals that morphed

\footnotetext{
${ }^{363}$ Bakunin quoted in E.H. Carr, Michael Bakunin (New York: Vintage Books, 1937), 175.

${ }^{364}$ Mikhail Bakunin, God and the State (Mineola, New York: Dover Publishing, 1970), 32.
} 
an appreciation of intellectual matters into a devotion to intellectualism. In themselves, the ideal of Reason, science, and various complementary notions were quite beneficial (and in line with the Enlightenment values both Bakunin and Kropotkin prized) to the progress of humanity and future anarchist revolutions. However, their consistent misuse and exploitation by the intelligentsia and the institutions associated with them led to a dangerous idolization of Reason and science as well as a usurpation of the Enlightenment ideals that undergirded much anarchist thought.

It was perhaps Stirner and Nietzsche who best understood the dangers Godwin, Proudhon, Bakunin, and Kropotkin highlighted in their treatment of Reason, science, and intellectualism. Stirner rejected the ostensibly emancipatory value of language, essentialism, and rationality while Nietzsche challenged the same through his analysis of the creative forces of the Dionysian, his rejection of moral absolutes, and his perspectivism. In this way, Stirner and Nietzsche sustained and magnified the antiintellectualist strain of anarchist thought and served as critical bridges to contemporary anarchist postfoundationalism.

It can be argued that Stirner and Nietzsche went a step further than simply highlighting our excessive devotion to Reason, science, intellectualism, and even truth. Indeed, they did not think "rationalization" was dangerous because it moved away from the Enlightenment ideals cherished by many so called classical anarchists or because they celebrated the ideals to the point of idolatry. Rather, they pointed to those very same Enlightenment ideals being dangerous. There were many thinkers that certainly thought 
Enlightenment ideals were being perverted but Stirner, Nietzsche, and their postfoundationalist interlocutors recognized dangers in these very ideals.

They highlighted the incoherence and futility of an overreliance on Reason and auxiliary notions like univocal understandings of human nature or the idea of progress. Nietzsche challenged our celebration of the Apollonian (i.e., the orderly, rational, and disciplined aspects of human thought and action) and rejected transcendental moral absolutes, while Stirner highlighted the arbitrariness of "fixed ideas," the limits of language in expressing ideas and guiding action, and the suffocating conceptual frameworks of understanding that limit genuine freedom.

While the Enlightenment tradition gave us a robust account of social and political obligation tied to strong conceptions of human nature and its relation to the state, Stirner undoes the Enlightenment inspired anthropocentrism of social contract theory while preserving the boundless pluralism only recognized through an embrace of absolute and unbridled individuality and autonomy. According to Stirner, intellectualism in this sense imprisons us in an existence justified by argumentation, rational reflection, and a dubious existential certainty. Stirner, like Nietzsche after him, sought to unravel the domination inherent in our intellects and free us from the limitations imposed by morality, religion, truth, and other "fixed ideas."

Nietzsche perhaps best sums up the thrust of the Stirnerian critique by noting, "life is not an argument." ${ }^{365} \mathrm{He}$ rails against the appeals to logic in the history of

\footnotetext{
${ }^{365}$ Friedrich Nietzsche, The Gay Science with A Prelude in German Rhymes and an Appendix of Songs, trans. Josephine Nauckhoff and Adrian Del Caro, ed. Bernard Williams (Cambridge: Cambridge University Press, 2001), 117.
} 
philosophy. While logic and our faculty of reason certainly have a practical use, they have little to do with any philosophical pretension to a discernment of reality for Nietzsche. An appeal to Reason and the intellectualism that is its symptom responds to an artificial and idealized version of the reality or truth it claims to be discovering.

A common thread in Stirner and Nietzsche's critique as well as in the antiintellectualism interrogated throughout Godwin's, Proudhon's, Bakunin's, and Kropotkin's work is a gravitation towards a sense of freedom that challenged orthodoxies in ostensibly non-political spheres (e.g., epistemology and ontology). All these thinkers, in one way or another, offer accounts of "creative destruction." They reflect the "passion for destruction" of, in their view, obsolete and stifling modes of thinking and a "creative passion" for thinking freely. ${ }^{366}$

\section{Freedom is a Contested Concept}

Thinking freely is the ultimate means and end for anarchist anti-intellectualism. It is also the means by which we are to construct free society along participatory lines. Without an ability to think freely we hinder our creative potential and our ability to interrogate our grounding philosophical assumptions. However, freedom in this sense is considered more broadly than simply an enlightened decision-making. Freedom is a contested concept. Modern notions of freedom are varied and embrace different guiding attitudes and philosophical orientations. As Mortimer Adler puts it in his study of the subject:

\footnotetext{
${ }^{366}$ Mikhail Bakunin famously expressed that "The passion for destruction is a creative passion, too!" in "The Reaction in Germany," accessed 5/16/2016, https://www.marxists.org/reference/archive/bakunin/works/1842/reaction-germany.htm.
} 
Burke countered the intemperance of the French Revolution by his own organic conception of liberty. Hegel, in attacking the great English Reform Bill of 1831, measured it against his own historical and evolutionary theory. Both the proponents and the enemies of the New Deal fought under banners of freedom... whereas the Anglo-American liberty, won chiefly through victories of dissenting religious sects, was mainly attentive to the rights of minorities, the French conception, owing much to Rousseau's theory of the General Will, and to the drastic course of revolution, put the emphasis on the sovereignty of the people and majority rights. ${ }^{367}$

Like Adler's work, most studies on the subject focus on civil or political liberty. A glaring omission in many studies on the idea of freedom is a thorough consideration of the anarchist tradition. Despite anarchism being the quintessential anti-authoritarian philosophy the idea of freedom in anarchist philosophy is seldom considered.

I have tried to dissect the idea of freedom and its relation to intellectualism in certain "canonical" anarchist thinkers. That is, I have tried firstly to understand the anarchist attitude towards bulwarks of our intellect (e.g., the ideal of Reason, the scientific method, and other foundational philosophical constructs like human nature and truth). I have also attempted to frame the anarchist attitude towards intellectualism within a wider consideration of intellectual freedom.

\footnotetext{
${ }^{367}$ Mortimer Adler, Freedom: A Study of the Development of the Concept in the English and American Traditions of Philosophy (Albany: Magi Books, 1968) 5-6.
} 
Anarchism is sometimes described as the "politics of anti-politics." 368 This notion of politics transcends the usual understanding of politics framed vis- $a$-vis the state. It seeks to apply our thinking of political categories (e.g., legitimacy, freedom, domination, authority) to every sphere of life. Indeed, for anarchists "politics" is a bit of a misnomer in that its concerns could very well apply to issues of hierarchy and authority that fall outside the scope of government. Likewise, "freedom" is usually envisioned within a framework of some sort of governance. Appreciating the anarchist conception of antiintellectualism requires us to think of anti-authoritarianism, freedom, and politics itself as existing in every realm of life. This conception of freedom, authority, and politics goes beyond Berlin's famed distinction between negative and positive liberty as well as beyond the republican notion of freedom as non-domination or freedom from structural and relational modes of domination. This freedom entails our ability to interrogate the very ontological foundation of freedom itself. This requires a healthy suspicion of the philosophical underpinnings of ostensible authoritative bulwarks of our intellect. Whether it is the governance of the state or our own rational self-legislation, anarchists envision freedom as a constant challenge to the authority and legitimacy of governance and share a suspicion of concentrations of power wherever they may be found. ${ }^{369}$

Anarchism shares this suspicion with everyone from Romanticists and Nietzscheans to poststructuralists and post-analytic philosophers. Indeed, there has been

\footnotetext{
${ }^{368}$ See Saul Newman, The Politics of Postanarchism (Edinburgh: Edinburgh University Press, 2010).

${ }^{369}$ In a consideration of the republican notion of freedom as non-domination, Philip Pettit considers powerful "doorkeepers" as obstacles to freedom. By pointing out that any kind of subjection (not just "frustration" or "interference") constitutes domination, Petit echoes the anarchist sentiment that even though nothing frustrates or interferes with our "rational self-legislation" we are nevertheless subject to the dictates of Reason (which is often-times exploited in ideological and institutional terms by priests, scientists, and intellectuals of all kinds). See Philip Pettit, "The Instability of Freedom as Noninterference: The Case of Isaiah Berlin,” Ethics, Vol. 73, Issue 1 (Jan 2012): 111-126.
} 
plenty of intellectual flirtation between anarchists, Nietzsche and Nietzscheans, and other postfoundationalist thinkers indicative of an emphatic anti-intellectualism and "return" to lived experience. Heidegger soon followed Nietzsche in his explicit appeal (beginning with his work in Being and Time) to the "priority of the practical, pretheoretical, social disclosure of the world." ${ }^{370}$ According to Gregory Smith, for Heidegger, "Authenticity implies a form of concernfully absorbed action, shaped by a pregiven ethos that eventuates in something like Aristotelian phronesis. ${ }^{\text {371 }}$ Indeed, what Smith calls the epicureanizing of thought is central to how to think of freedom beyond the theoretical or philosophical and as intimately tied to sensual lived experience. ${ }^{372}$

Just as easily as the so-called classical anarchists would invoke Reason to justify anarchist action, so too would they invoke emotion and improvisation as the path towards liberation. Reflexively appealing to our emotions or improvisation in this way is a clear rejection of determinism. Indeed, the idea of self-determination can sometimes mean that our freely chosen acts should not be caused by preexisting conditions (including any kind of rational determinism). ${ }^{373}$ Likewise, our thinking, in so far as it is freely undertaken, should not be saddled with tradition, limiting conceptions of, as Heidegger put it, our thinking being (i.e., ridding ourselves of "spooks" as Stirner would put it), nor should it

\footnotetext{
${ }^{370}$ Smith, 288.

${ }^{371}$ Ibid, 205.

${ }^{372}$ Ibid, 292 n. 14

${ }^{373}$ Adler, 36.
} 
hinge on one overriding univocal ideal of Reason. As Svetlana Boym asserts, "The examination of freedom requires a creative logic of its own. ${ }^{374}$

\section{Thinking Freely}

By pushing the boundaries of existing anarchist scholarship by thinking about open-ended alternatives to conceiving of freedom in the realm of the intellect I attempt to describe what it means to think freely. This entails an understanding of antiintellectualism that embraces anarchist anti-authoritarian values and applies them to our ontological and epistemological presuppositions as well as to the foundations of anarchist thought (which themselves are constantly negotiated by anarchists of all stripes).

Svetlana Boym best echoes anarchist sentiments on the matter when she notes

Possibly the only way to discover or rescue alternative frameworks of freedom for the twenty-first century is through thinking freedom neither as the means for an end nor as an end that justifies the means but simultaneously as means and ends, or as something that defies the means - and - ends rationale altogether. ${ }^{375}$

In order to fuse means and ends we need to rid ourselves of intellectual banisters. Boym continues,

In the extreme circumstances of twentieth-century history, the banister of social common places and familiar clichés can turn into a scandala, an obstacle that leads to a moral scandal and foundation for the 'banality of evil.' One has to think

\footnotetext{
${ }^{374}$ Boym, 3.

${ }^{375}$ Ibid, 16.
} 
through these radical breaks in the twentieth-century tradition that alter the way we measure things; otherwise one person's banisters can turn into another's barbed wire. $^{376}$

Arendt was quite clear on the topic as well. Our need for bannisters or the cold comfort of Reason "is not inspired by the quest for truth but by the quest for meaning. And truth and meaning are not the same." ${ }^{, 377}$ And, she notes, "The quest for meaning is 'meaningless' to common sense and common-sense reasoning because it is the sixth sense's function to fit us into the world of appearances and make us at home in the world given by our five senses; there we are and no questions asked."378 She continues, And not only is the quest for meaning absent from and good for nothing in the ordinary course of human affairs, while at the same time its results remain uncertain and unverifiable; thinking is also somehow self-destructive...From which it follows that the business of thinking is like Penelope's web; it undoes every morning what it has finished the night before. For the need to think can never be stilled by allegedly definite insights of 'wise men'; it can be satisfied only through thinking, and the thoughts I had yesterday will satisfy this need today only to the extent that I want and am able to think them anew. ${ }^{379}$

\footnotetext{
${ }^{376}$ Ibid, 29.

${ }^{377}$ Hannah Arendt, The Life of the Mind (San Diego: Harcourt, 1978), 15.

${ }^{378}$ Ibid, 59.

${ }^{379}$ Ibid, 88.
} 
In the Arendtian sense, it is impossible to derive meaning from thinking. Especially when that thought is grounded in an enterprise whose very foundation is fleeting.

For Paul Feyerabend, attempting to ground this fleeting foundation in the apparent stability of an "outside world" or concrete reality through empirical scientific evidence is equally absurd. According to Feyerabend, a "democratic criticism of science... belongs to the nature of knowledge." ${ }^{380}$ No matter how "productive" science might be, its results have nothing to do with its validity or desirability and should be challenged by anyone. ${ }^{381}$ In much the same vein as Rorty's idea of the arbitrariness of "final vocabularies," Feyerabend also claims "A tradition assumes desirable or undesirable properties only when compared with some tradition..." ${ }^{, 32}$ The freedom to challenge Reason (and the tradition that celebrates it) intelligibly and creatively is an integral part of thinking freely.

Feyerabend squarely describes the stifling effects of an unchallenged Reason in political terms. He notes,

The teaching of standards and their defence never consists merely in putting them before the mind of the student and making them as clear as possible. The standards are supposed to have maximal causal efficacy as well. This makes it very difficult indeed to distinguish between the logical force and the material effect of an argument. Just as a well-trained pet will obey his master no matter how great the confusion in which he finds himself, and no matter how urgent the

\footnotetext{
${ }^{380}$ Paul Feyerabend, The Tyranny of Science (Cambridge: Polity Press, 2011), 36.

${ }^{381}$ See Paul Feyerabend, Science in a Free Society (London: Verso, 1982).

${ }^{382}$ Ibid, 27.
} 
need to adopt new patterns of behavior, so in the very same way a well-trained rationalist will obey the mental image of his master, he will conform to the standards of argumentation he has learned, he will adhere to these standards no matter how great the confusion in which he finds himself, and he will be quite incapable of realizing that what he regards as the 'voice of reason' is but a causal after-effect of the training he has received. He will be quite unable to discover that the appeal to reason to which he succumbs so readily is nothing but a political manoeuver. ${ }^{383}$

According to Feyerabend, to overcome this "political maneuver," itself steeped in the unequal and many times authoritarian institutions of learning, there is a necessity to eliminate the alien otherworldliness being imposed by the "standards" of reason, science, and ideals of all sorts. He notes,

We must expect, for example, that the idea of liberty could be made clear only by means of the very same actions, which were supposed to create liberty. Creation of a thing, and creation plus full understanding of a correct idea of the thing, are very often parts of one and the same indivisible process and cannot be separated without bringing the process to a stop. The process itself is not guided by such a programme, for it contains the conditions for the realization of all possible programmes. It is guided rather by a vague urge, by a 'passion' (Kierkegaard). The passion gives rise to specific behavior which in turn creates the circumstances

\footnotetext{
${ }^{383}$ Paul Feyerabend, Against Method: Outline of an Anarchist Theory of Knowledge (London: Verso, 1978), 25.
} 
and the ideas necessary for analyzing and explaining the process, for making it 'rational.' 384

In other words, Feyerabend echoes the anarchist aspiration of eliminating any kind of means and ends rationality.

This is in line with Wittgenstein's idea that our concepts depend on our own lived experiences. As Hanna Pitkin puts it in her study of Wittgenstein “...the nature of our concepts itself depends on our lives as animate creatures in the world." 385 The increasing disconnects between means and ends, between lived experience and ideational goals, leads to the tragedies critics of the Enlightenment have assailed. Pitkin eloquently describes how high-minded emancipatory Enlightenment ideals could degenerate into the "iron cage" decried by critical theorists of many stripes for precisely this reason. She notes,

The hidden, the repressed, the distorted, the content of 'false consciousness,' also varies with person, culture, and time. Indeed, what is a liberating philosophical insight for one generation can become the encrusted and misleading conventional wisdom of the next. Successful philosophy allows the inquiring mind to discover what it needs to know about itself or the world; great philosophy performs this service for us all. ${ }^{386}$

\footnotetext{
${ }^{384}$ Ibid, 26.

${ }^{385}$ Hanna Fenichel Pitkin, Wittgenstein and Justice: On the Significance of Ludwig Wittgenstein for Social and Political Thought (Berkeley: University of California Press, 1972), 116.

${ }^{386}$ Ibid, 295.
} 
Pitkin's insistence on the Wittgensteinian point that we co-create "great philosophy" in so far as it serves us all (not just the "inquisitive" few) is central to the postfoundational effort to include any who might care to consider notions like "truth," "reason," "justice," or similar instances of "final vocabularies" as largely beside the point.

Willingness to reassess and "be impressed" by other vocabularies and admit those vocabularies are not connected to anything beyond ourselves breaks open possibilities that any metaphysical grounding of thought would exclude. ${ }^{387}$ The challenge of translating the emancipatory potential of this "ironism" to the political is something the anarchist tradition is uniquely poised to do. By already considering politics beyond government and the state, anarchists are attuned to how ironism could help sketch the possibilities of thinking freely in a way philosophers like Rorty failed to appreciate.

According to Rorty, his defense of ironism

...turns on making a firm distinction between the private and the public. Whereas Habermas sees the line of ironist thinking which runs from Hegel through Foucault and Derrida as destructive of social hope, I see this line of thought as largely irrelevant to public life and to political questions. Ironist theorists like Hegel, Nietzsche, Derrida, and Foucault seem to me invaluable in our attempt to form a private self-image, but pretty much useless when it comes to politics.

Habermas assumes that the task of philosophy is to supply some social glue which

${ }^{387}$ Rorty, Contingency, Irony, and Solidarity, 73. 
will replace religious belief, and to see Enlightenment talk of 'universality' and 'rationality' as the best candidate for this glue. ${ }^{388}$

While Rorty considers ironism useless when it comes to politics, the anarchist conception of anti-intellectualism seeks to apply this same reconsideration of "final vocabularies" to a shared skepticism of the social institutions that relay knowledge all the while rejecting the "Enlightenment talk" of "universality" and "rationality" as any kind of redeeming "social glue." However, how can we make public that which, according to Rorty, is exclusively private? How can we reflect the ironism meant to "form a private self-image" in our politics and relations with others? The answer lies largely in the contingency and improvisation inherent in anarchism as a political movement and form of association with others.

While Rorty holds that "The metaphysician, in short, thinks that there is a connection between redescription and power, and that the right redescription can make us free," the ironist "offers no similar assurance." ${ }^{389}$ The anarchist similarly offers no resolution in the form of a correct redescription and hopes to transfer such a dismissal of the force of redescription to the public realm. Anarchists' political attitudes are already imbued by their own ironism and action oriented understandings of meaning. Anarchists already believe that any kind of metaphysical grounding or accurate redescription of reality will not yield freedom. Only direct action aligning our anti-authoritarian means with our emancipatory ends will yield anything similar. Their refusal to ossify any

\footnotetext{
${ }^{388} \mathrm{Ibid}, 83$.

${ }^{389}$ Ibid, 90.
} 
political order or ideal precisely under the banner of freedom is what makes anarchism an ideal channel to navigate its own lively anti-intellectualism towards a public ironism and a continued resistance to arbitrary authority in any sphere.

This navigation should not simply be derivative of postfoundational attitudes towards "grand narratives" and "totalizing notions" that Habermas and Rorty appropriately consider politically sterile. Rather, in a Wittgensteinian vein, we should endeavor to think like anarchists. When we care to consider how to think like an anarchist we are not only contemplating a general suspicion towards concentrations of political, economic, and ecclesiastical power, or simply reflecting on how best to constitute a society with voluntary institutions based on the principle of free association so integral to anarchist philosophy. Instead, we are also aspiring to think without "banisters," and make public our ironism, essentially improvising without the comfort of a political blueprint. That is, we are thinking freely. 


\section{Bibliography}

Adler, Mortimer, Freedom: A Study of the Development of the Concept in the English and American Traditions of Philosophy. Albany: Magi Books, 1968.

Adorno, Theodor, Negative Dialectics, trans. E.B. Ashton. New York: Continuum International Publishing Group, 1973.

Agger, Ben, "Critical Theory, Poststructuralism, Postmodernism." Annual Review of Sociology 17 (1991): 105-131.

Arendt, Hannah, The Life of the Mind. San Diego: Harcourt, 1978.

Anarchy Archives. "Proudhon's letter to Marx dated 17 May, 1846." Accessed August $14^{\text {th }}, 2015$,

http://dwardmac.pitzer.edu/Anarchist_Archives/proudhon/letters/proudhontomarx.html

Anarchy Archives. "Letters from: Proudhon, P-J. (1875) Correspondance de P. J. Proudhon; Tome Troisiéme Librairie Internationale; Paris." Accessed, August 14 ${ }^{\text {th }}, 2015$. http://dwardmac.pitzer.edu/Anarchist_Archives/proudhon/letters/letters.html

Aquinas, Thomas $O f$ God and His Creatures: An Annotated Translation (with some abridgments) Summa Contra Gentiles, trans. Joseph Rickaby. Westminster, MD: The Carroll Press, 1950.

Aristotle, Politics. Translated by C. D. C. Reeve. Indianapolis: Hackett, 1998.

Avrich, Paul "Anarchism and Anti-Intellectualism in Russia," Journal of the History of Ideas, Vol. 27, No. 3 (1966).

Avrich, Paul, Anarchist Portraits. Princeton: Princeton University Press, 1988.

Avrich, Paul, The Russian Anarchists. Princeton: Princeton University Press, 1967.

Bakunin, Mikhail, The Basic Bakunin: Writings, 1869-1871 Edited and translated by Robert M. Cutler. Buffalo, NY: Prometheus, 1992.

Bakunin, Mikhail, The Political Philosophy of Mikhail Bakunin: Scientific Anarchism. Edited by G.P. Maximoff. New York: The Free Press, 1953.

Bakunin, Mikhail, Statism and Anarchy. Edited by Marshall Shatz. Cambridge: Cambridge University Press, 2005.

Bakunin, Mikhail, God and the State. Mineola, New York: Dover Publishing, 1970. 
Bakunin, Mikhail, "The Reaction in Germany.” Accessed December 26, 2014, https://www.marxists.org/reference/archive/bakunin/works/1842/reaction-germany.htm Bennett, Jane and William E. Connolly, "Contesting Nature/Culture: The Creative Character of Thinking." The Journal of Nietzsche Studies, Issue 24, (Fall 2002): 148-163.

Berlin, Isaiah, Russian Thinkers. New York: Penguin Books, 2008.

Berlin, Isaiah, Three Critics of the Enlightenment: Vico, Hamann, Herder. Princeton: Princeton University Press, 2013.

Blumenfeld, Jacob, Chiara Bottici, and Simon Crtitchley, ed. The Anarchist Turn. London: Pluto Press, 2013.

Boym, Svetlana, Another Freedom: The Alternative History of an Idea. Chicago: University of Chicago Press, 2010.

Brandom, Robert B, ed. Rorty and his Critics. Oxford: Blackwell Publishers, 2000.

Brown, Susan L. The Politics of Individualism. Montreal: Black Rose Books, 2003.

Burbules, Nicholas C. and Paul Smeyers, "Wittgenstein, The Practice of Ethics, and Moral Education.” Accessed on September, 18, 2012, http://faculty.education.illinois.edu/burbules/papers/wittethics.html

Call, Lewis, Postmodern Anarchism. Lanham, MD: Lexington Books, 2003.

Carr, E.H., Michael Bakunin. New York: Vintage Books, 1937.

Cohn, Jesse, Anarchism and the Crisis of Representation: Hermeneutics, Aesthetics, Politics. Selinsgrove, PA: Susquehanna University Press, 2006.

Cohn, Jesse, "What's Wrong With Postanarchism? Accessed Febuary19, 2015, http://theanarchistlibrary.org/library/jesse-cohn-and-shawn-wilbur-what-s-wrong-withpostanarchism.

Collings, David, "The Romance of the Impossible: William Godwin in the Empty Place of Reason" English Literary History, 70:3 (2003): 847-874.

Connolly, William, Political Theory and Modernity. Oxford: Blackwell, 1988.

el-Dahdah, Farès, Pierre-Joseph Proudhon "Letter from Pierre-Joseph Proudhon to Karl Marx", Assemblage, 41 (April, 2000): 21. 
Dallmayr, Fred, "The Politics of Non-Identity: Adorno, Postmodernism - And Edward Said", Political Theory, Vol. 25 No. 1, February (1997): 33-56.

Derrida, Jacques, Of Grammatology, trans. Gayatari Chakravorty Spivak. Baltimore: Johns Hopkins University Press, 1997.

Derrida, Jacques, Positions, trans Alan Bass. Chicago: University of Chicago Press, 1982.

Descartes, Rene, Discourse on Method; and, Meditations on First Philosophy. Translated by Donald A. Cress. Indianapolis: Hackett, 1998.

Detwiler, Bruce, Nietzsche and the Politics of Aristocratic Radicalism. Chicago: The University of Chicago Press, 1990.

Frankfurt, Harry G., Demons, Dreamers, and Madmen: The Defense of Reason in Descartes's Meditations. New York: The Bobbs-Merril Company, 1970.

Feuerbach, Ludwig, Principles of the Philosophy of the Future. Translated by Manfred H. Vogel. Indianapolis: Hackett Publishing, 1986.

Feyerabend, Paul, Against Method: Outline of an anarchistic theory of knowledge. London: Verso, 1978.

Feyerabend, Paul, Farewell to Reason. London: Verso, 1987.

Feyerabend, Paul, The Tyranny of Science. Cambridge: Polity Press, 2011.

Feyerabend, Paul, Science in a Free Society. London: Verso, 1982.

Flathman, Richard E., Reflections of a Would-Be Anarchist: Ideals and Institutions of Liberalism. Minneapolis: University of Minnesota Press, 1998.

Foucault, Michel The Archeology of Knowledge, trans. A.M. Sheridan Smith. New York: Pantheon Books, 1972.

Fritsch, Matthias, "Derrida's Democracy to Come," Constellations: An International Journal of Critical and Democratic Theory, 9:4 (2002): 574-597.

Fukuyama, Francis, The End of History and the Last Man. New York: Simon and Schuster, 2006.

Godwin, William, Enquiry Concerning Political Justice and its Influence on Modern Morals and Happiness. Harmondsworth, Middlesex, England: Penguin Books, 1976 [1798]. 
Godwin, William, Caleb Williams. Peterborough, Ontario, Canada: Broadview literary texts, 2000.

Godwin, William, St. Leon: A Tale of the Sixteenth Century. New York: Arno Press, 1972.

Godwin, William, Caleb Williams. Peterborough, Ont.: Broadview Press, 2000.

Godwin, William, Fleetwood, or The New Man of Feeling. Peterborough, Ont.:

Broadview Press, 2001.

Goldman, Emma, Living My Life. New York: Knopf, 1934.

Golomb, Jacob, and Robert S. Wistrich, ed. Nietzsche, Godfather of Fascism? On the Uses and Abuses of a Philosophy. Princeton: Princeton University Press, 2002.

Graham, Robert, ed., Anarchism: A Documentary History of Libertarian Ideas. Montreal: Black Rose Books, 2004.

Guzzini, Stefano and Anna Leander, ed., Constructivism and International Relations: Alexander Wendt and his critics. New York: Routledge, 2006.

Habermas, Jürgen, The Philosophical Discourse of Modernity, trans. Frederick G. Lawrence. Cambridge: MIT Press, 2000.

Habermas, Jürgen, The Theory of Communicative Action, Volume 1: Reason and the Rationalization of Society. Boston: Beacon Press, 1984.

Habermas, Jürgen, Toward a Rational Society, trans. J.J. Shapiro. Boston, Beacon, 1970.

Habermas, Jürgen, Moral Consciousness and Communicative Action, trans. C. Lenhardt and S.W. Nicholsen. Cambridge, Mass.: MIT Press, 1990.

Heiddeger, Martin, What is Called Thinking? trans. by J. Glenn Gray. New York: Harper Collings, 2004.

Hoffman, Robert, L. Revolutionary Justice: The Social and Political Theory of P.J. Proudhon. Urbana: University of Illinois Press, 1972.

Horkheimer, Max and Theodore Adorno, Dialectic of the Enlightenment: Philosophical Fragments. Edited by Gunzelin Schmid Noerr, trans., Edmund Jephcott. Palo Alto: Stanford University Press, 2002. 
Hume, David, A Treatise of Human Nature, ed. David Fate Norton and Mary J. Norton. Oxford; New York: Oxford University Press, 2000.

Hume, David, A Treatise of Human Nature. Edited by David Fate Norton and Mary J. Norton. Oxford; New York: Oxford University Press, 2000.

Israel, Jonathan, Radical Enlightenment: Philosophy and the Making of Modernity 16501750. Oxford: Oxford University Press, 2001.

James, William, A Pluralistic Universe [iBook].

Jameson, Frederic, Postmodernism, or, The Cultural Logic of Late Capitalism. Durham: Duke University Press, 1991.

Jolley, Kelly Dean, ed. Wittgenstein: Key Concepts. Durham, UK: Acumen, 2010.

Jun, Nathan, Anarchism and Political Modernity. New York: Continuum, 2012.

Kant, Immanuel, Groundwork of the Metaphysics of Morals. Edited by Mary Gregor. Cambridge: Cambridge University Press, 1997.

Kant, Immanuel, Critique of Pure Reason, trans. by Norman Kemp Smith. New York: St. Martin's Press, 1965.

Kant, Immanuel, Critique of Practical Reason, trans. by Lewis White Beck. Indianapolis: Bobbs-Merill, 1956.

Kaufmann, Walter, Nietzsche: Philosopher, Psychologist, Antichrist. Princeton: Princeton University Press, 1950.

Klausen, Jimmy Casas and James Martel, ed. How Not To Be Governed: Readings and Interpretations from a Critical Anarchist Left. Lanham: Lexington Books, 2011.

Koch, Andrew M. "Poststructuralism and the Epistemological Basis of Anarchism", Philosophy and the Social Sciences 23 (1993): 327-351.

Kramnick, Issac, ed., The Portable Enlightenment Reader. New York: Penguin Books, 1995.

Kripke, Saul A. Wittgenstein on Rules and Private Language. Cambridge: Harvard University Press, 1982.

Kropotkin, Peter, The Conquest of Bread and Other Writings. Edited by Marshall S. Shatz. Cambridge: Cambridge University Press, 1995. 
Kropotkin, Peter, Mutual Aid: A Factor in Evolution. Forgotten Books, 2008[1902].

Kropotkin, Peter, Anarchism: A Collection of Revolutionary Writings. Edited by Roger N. Baldwin. Mineola: Dover Publications, 1970.

Kropotkin, Peter, "Brain Work and Manual Work.” Accessed February 7, 2016, http://dwardmac.pitzer.edu/Anarchist_Archives/kropotkin/brainmanualwork.html.

Kropotkin, Peter, 1897, “Anarchist Morality.” Accessed 10/29/2014. https://www.marxists.org/reference/archive/kropotkin-peter/1897/morality.htm

Kropotkin, Peter, "Kropotkin: Representative Government." Accessed July 27, 2016, https://robertgraham.wordpress.com/2012/12/24/kropotkin-representative-government/

Kuhn, Thomas, The Structure of Scientific Revolutions. Chicago: University of Chicago Press [1962] 1996.

Lakatos, Imre, Criticism and the Growth of Knowledge. Edited by Alan Musgrave. Cambridge: Cambridge University Press, 1970.

Leier, Mark, Bakunin: The Creative Passion. New York: St. Martin's Press, 2006.

Locke, John, An Enquiry Concerning Human Understanding. Edited by Kenneth P. Winkler. Indianapolis: Hackett, 1996.

Lyotard, Jean-Francois, The Postmodern Condition: A Report on Knowledge. Minneapolis: University of Minnesota Press, 1984.

May, Todd, The Political Philosophy of Poststructuralist Anarchism. University Park, PA: The Pennsylvania State University Press, 1994.

Marshall, Peter, Demanding the Impossible: A History of Anarchism. Oakland: PM Press, 2010.

Martin, Thomas, "New Remedies or New Evils? Anarchism and the Scientific Revolution" in New Perspectives of Anarchism. Edited by Nathan J. Jun and Shane Wahl. Lanhan: Lexington Books, 2010.

Marx, Karl, The German Ideology. USA: Prometheus Books, 1998.

McGeough, Jared, "Romanticism after the Anarchist Turn." Literature Compass, volume 13, number 1 (2016): 3-12.

McLaughlin, Paul, Mikhail Bakunin: The Philosophical Basis of his Anarchism. New York: Algora Publishing, 2002. 
Megill, Allan, Karl Marx: The Burden of Reason (Why Marx Rejected Politics and the Market). Lanham, MD: Rowman and Littlefield Publishers, 2002.

Monk, Ray, How to Read Wittgenstein. New York: W.W. Norton and Company, 2005.

Moore, John and Spencer Sunshine eds. I Am Not A Man, I Am Dynamite! Friedrich Nietzsche and the Anarchist Tradition. New York: Autonomedia, 2004.

Morris, Brian, Kropotkin: The Politics of Community. Amherst: Humanity Books, 2004.

Newman, Saul, Unstable Universalities: Poststructuralism and Radical Politics. Manchester: Manchester University Press, 2008.

Newman, Saul, ed., Max Stirner. New York: Palgrave Macmillan, 2010.

Newman, Saul, From Bakunin to Lacan: Anti-Authoritarianism and the Dislocation of Power. Lanham, MD: Lexington Books, 2001.

Newman, Saul, The Politics of Postanarchism. Edinburgh: Edinburgh University Press, 2011.

Nietzsche, Friedrich, The Gay Science with A Prelude in German Rhymes and an Appendix of Songs, trans. Josephine Nauckhoff and Adrian Del Caro, ed. Bernard Williams. Cambridge: Cambridge University Press, 2001.

Nietzsche, Friedrich, The Will to Power, trans. Walter Kaufmann and R.J. Hollingdale, ed. Walter Kaufmann. New York: Vintage, 1968.

Nietzsche, Friedrich, The Anti-Christ, Ecce Homo, Twilight of the Idols and Other Writings, ed. Aaron Ridley and Judith Norman. Cambridge: Cambridge University Press, 2005.

Nietzsche, Friedrich, Thus Spoke Zarathustra: A Book For Everyone and No One.

London: Penguin, 2003.

Oakeshott, Michael, Rationalism in Politics and Other Essays. Indianapolis: Liberty Press, 1991.

Paterson, R.W.K., The Nihilistic Egoist Max Stirner. London: Oxford University Press, 1971.

Pettit, Philip "The Instability of Freedom as Noninterference: The Case of Isaiah Berlin." Ethics, Vol. 73, Issue 1 (Jan 2012): 111-126. 
Pitkin, Hanna Fenichel, Wittgenstein and Justice: On the Significance of Ludwig Wittgenstein for Social and Political Thought. Berkeley: University of California Press, 1972.

Pippin, Robert, Modernism as a Philosophical Problem: On the Dissatisfactions of European High Culture. Cambridge, Mass.: Basil Blackwell, 1991.

Plato, Republic, translated by Robin Waterfield. Oxford: New York: Oxford University Press, 1994.

Popper, Karl, The Logic of Scientific Discovery. New York: Routledge, 1992.

Priestly, F.E.L., "Platonism in William Godwin's Political Justice” Modern Language Quarterly, 1943, 4: 1 (2007): $63-69$.

Proudhon, Pierre-Joseph, What is Property? Edited by Donald R. Kelley and Bonnie G. Smith. Cambridge: Cambridge University Press, 1994.

Proudhon, Pierre-Joseph, The General Idea of the Revolution in the Nineteenth Century. Translated by John Beverly Robinson. London: Pluto Press, 1989.

Proudhon, Pierre-Joseph, General Idea of the Revolution in the Nineteenth Century. New York: Gordon Press, 1972.

Proudhon, Pierre-Joseph, System of Economic Contradictions or, The Philosophy of Misery. New York: Arno Press, 1972 [1888].

Quine, W.V.O., Ontological Relativity and Other Essays. New York: Columbia University Press, 1969.

Rajchman, John and Cornel West, ed. Post-Analytic Philosophy. New York: Columbia University Press, 1985.

Ranibow, Paul, ed., The Foucault Reader. New York: Pantheon Books, 1984.

Reiss, H.S. ed., Kant: Political Writings. Cambridge: Cambridge University Press, 1991.

Richard Rorty, Contingency, Irony, Solidarity. Cambridge: Cambridge University Press, 1989.

Richard Rorty, Essays on Heidegger and Others. Cambridge: Cambridge University Press, 1991.

Ritter, Alan, The Political Thought of Pierre Joseph Proudhon. Princeton: Princeton University Press, 1969. 
Robertson, Ann, "The Philosophical Roots of the Marx-Bakunin Debate." Accessed October 17, 2012, http://www.marxists.org/reference/archive/bakunin/bio/robertsonann.htm.

Saint-Amand, Pierre and Sophie Hawkes, "Contingency and the Enlightenment", in SubStance, Vol.26, No.2, Issue 83(1997): 96-109.

Scott, James, Seeing Like a State: How Certain Schemes To Improve The Human Condition Have Failed. New Haven: Yale University Press, 1998.

Sedgwick, Peter R. ed. Nietzsche: A Critical Reader. Cambridge: Blackwell, 1995.

Simmons, John A. “Justification and Legitimacy,” Ethics 109: 4 (July 1999): 739-771.

Smith, Gregory Bruce, Nietzsche, Heidegger, and the Transition to Postmodernity. Chicago: University of Chicago Press, 1996.

Stirner, Max, The Ego and its Own, ed. David Leopold. Cambridge: Cambridge University Press, 1995.

Strauss, Leo, Persecution and the Art of Writing. Chicago: University of Chicago Press, 1998.

Strauss, Leo, What is Political Philosophy? Chicago: University of Chicago Press, 1988.

Strong, Tracy B., Friedrich Nietzsche and the Politics of Transfiguration. Berkeley: University of California Press, 1975.

Thiele, Leslie Paul Timely Meditations: Martin Heidegger and Postmodern Politics. Princeton: Princeton University Press, 1995.

Ward, Ian, "A Love of Justice: the legal and political thought of William Godwin." The Journal of Legal History, 25:1 (2004).

Ward, Ian, “A Man of Feelings: William Godwin's Romantic Embrace” in Law and Literature, 17: 1 (2005): 21-46.

Weber, Max, The Essential Weber. Edited by Sam Whimster. New York: Routledge, 2004.

Weber, Max, The Vocation Lectures. Edited by David Owen and Tracy B. Strong, translated by Rodney Livingstone. Cambridge: Hackett, 2004. 
Weston, Rowland, "Politics, Passion and the 'Puritan Temper': Godwin's Critique of Enlightened Modernity." Studies in Romanticism, 41: 3 (Fall 2002): 447-452.

Weston, Rowland, "Radical Enlightenment and Anti-Modernism: The Apostasy of William Godwin (1756-1836)" in The Journal for the Study of Radicalism, 7:2 (Fall 2013): 1-30.

Wittgenstein, Ludwig, Philosophical Investigations, Translated by G.E.M. Anscombe, P.M.S. Hacker and Joachim Schulte. Oxford: Wiley-Blackwell, 2009.

Woodcock, George, Anarchism: A History of Libertarian Ideas and Movements. Cleveland: Meridian Books, 1962.

Working Translations: Writings by Anarchists, Socialists, Feminists and Dreamers, translated from the French. "Pierre-Joseph Proudhon, Justice in the Revolution and in the Church, Vol. 1 (in progress)." accessed August 14 ${ }^{\text {th }}, 2015$, http://workingtranslations.blogspot.com/p/pierre-joseph-proudhon-justice-in.html. 
VITA

\section{JOAQUIN A. PEDROSO}

2004-2008

2009-2012

2012-2015

$2015-2016$

2016
B.A., Philosophy, Second Major in Political Science

Florida International University

Miami, Florida

M.A., Political Science

Florida International University

Miami, FL

Teaching Assistant

Florida International University

Miami, FL

Instructor

Florida International University

Miami, FL

Adjunct Professor

Florida International University

Miami, FL

Adjunct Professor

Miami Dade College - Kendall

Miami, FL 


\section{PUBLICATIONS AND PRESENTATIONS}

Book Review. Pedroso, J. (May 2011). John Foley, Albert Camus: From the Absurd to Revolt in Political Studies Review, Volume 9, Issue 2 (May 2011), p. 226.

Pedroso, J. (October, 2011) Power/Knowledge and Human Nature: A Critical Assessment of Foucauldian Anti-Essentialism. Paper presented at the FIU Graduate Student Committee Lecture Series, Miami, Florida.

Book Review. Pedroso, J. (January 2012). Fredric Jameson, Valences of the Dialectic in Political Studies Review, Volume 10, Issue 1, p. 91.

Pedroso, J. (April 2012) Power/Knowledge and Human Nature: A Critical Assessment of Foucauldian Anti-Essentialism. Paper presented at the meeting of the Mid-West Political Science Association, Chicago, Illinois.

Book Review. Pedroso, J. (May 2012). (Ed.) Raia Prokhovinik and Gabriella Slomp, International Political Theory After Hobbes: Analysis, Interpretation and Orientation in Political Studies Review, Volume 10, Issue 2, pp. 244-245.

Pedroso, J. (January, 2013) Power/Knowledge and Human Nature: A Critical Assessment of Foucauldian Anti-Essentialism. Paper presented at the meeting of the Southern Political Science Association, Orlando, Florida.

Pedroso, J. (April, 2014) Anarchism, Reason, and Consistent Anti-Authoritarianism. Paper presented at the meeting of the Western Political Science Association, Seattle, Washington.

Pedroso, J. (October, 2014) Anti-Authoritarianism as Anti-Intellectualism: Two Attempts. Paper presented at the meeting of the Comparative Studies Student Association, Florida Atlantic University, Boca Raton, FL.

Pedroso, J. (March, 2015) Anti-Authoritarianism as Anti-Intellectualism: Stirner, Nietzsche, and Postfoundational Anarchism. Paper presented at the North American Anarchist Studies Network (NAASN), California Institute for Integral Studies, San Francisco, CA. 